This report was prepared as an account of work sponsored by an agency of the United States Government. Neither the United States Government nor any agency thereof, nor any of their employees, makes any warranty, express or implied, or assumes any legal liability or responsibility for the accuracy, completeness, or usefulness of any information, apparatus, product, or process disclosed, or represents that its use would not infringe privately owned rights. Reference herein to any specific commercial product, process, or service by trade name, trademark, manufacturer, or otherwise, does not necessarily constitute or imply its endorsement, recommendation, or favoring by the United States Government or any agency thereof. The views and opinions of authors expressed herein do not necessarily state or reflect those of the United States Government or any agency thereof. 
US ITER 12106-TD0003-R00

2.6P1A B.US.01.0

\title{
DRAIN TANK INFORMATION FOR DEVELOPING DESIGN BASIS OF THE PRELIMINARY DESIGN
}

\author{
Juan J. Ferrada \\ Jan Berry
}

Date Published: December 2010

Prepared by

Tokamak Cooling Water System

U.S. ITER

Prepared by

OAK RIDGE NATIONAL LABORATORY

Oak Ridge, Tennessee 37831-6283

managed by

UT-BATTELLE, LLC

for the

U.S. DEPARTMENT OF ENERGY

under contract DE-AC05-00OR22725 



\section{DRAIN TANK INFORMATION FOR DEVELOPING DESIGN BASIS OF THE PRELIMINARY DESIGN}

December 2010

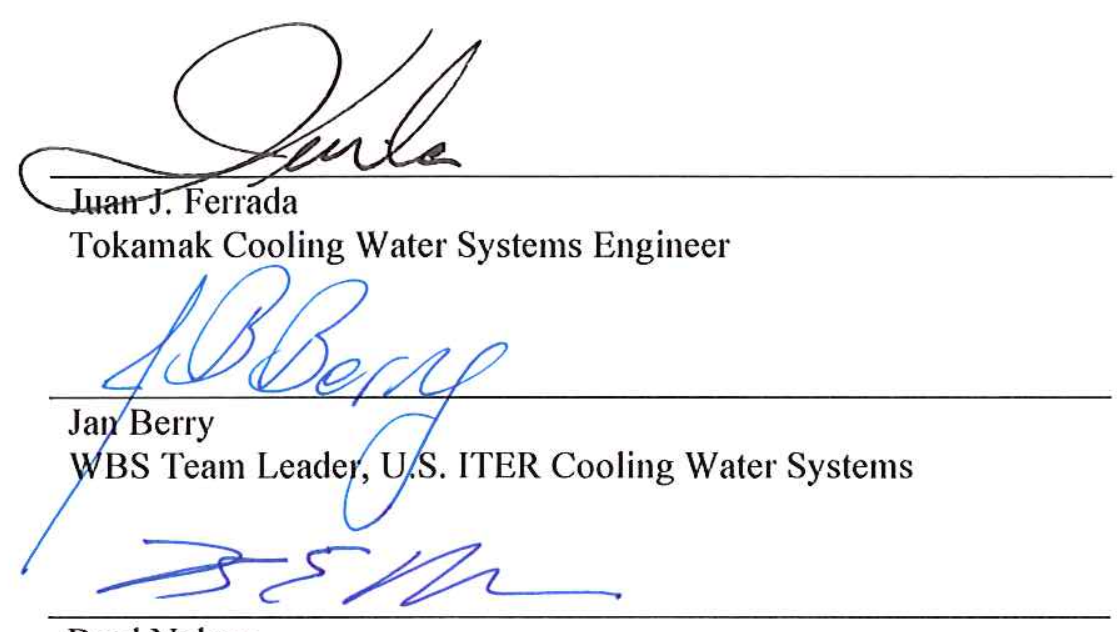

Brad Nelson

$\frac{1.5 \cdot 11}{\text { Date }}$

Chief Engineer, U.S. ITER
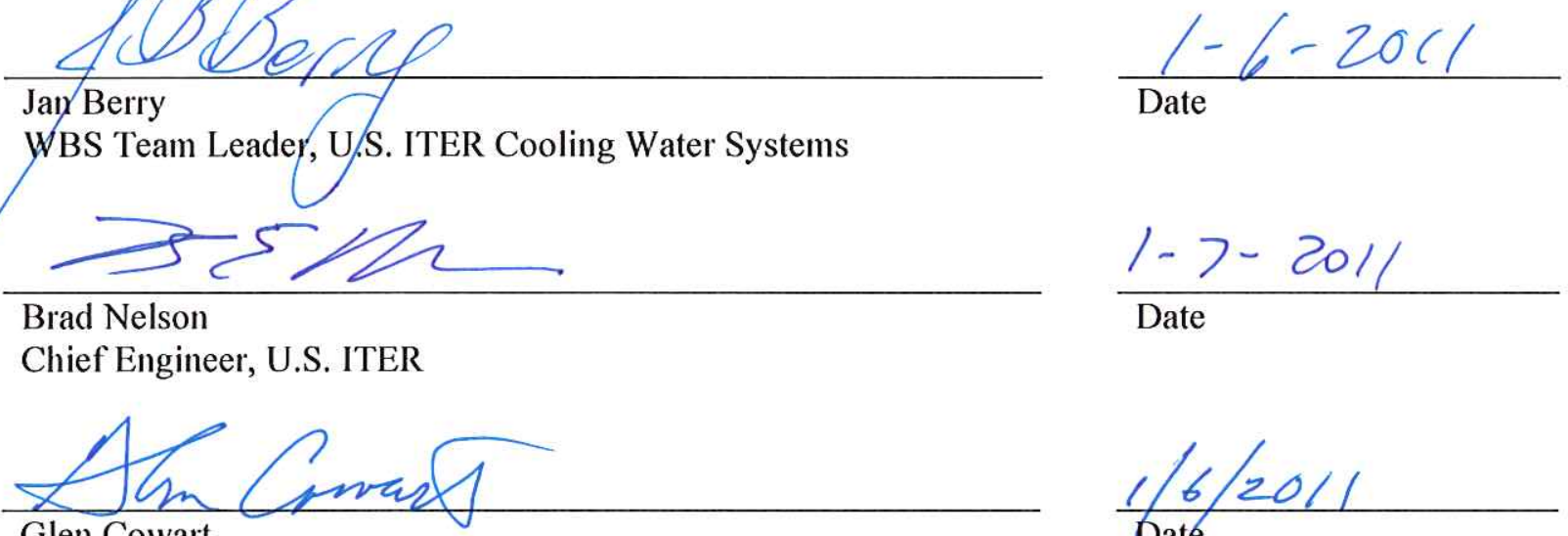

Glen Cowart

$1-7-2011$

QA Manager, U.S. ITER

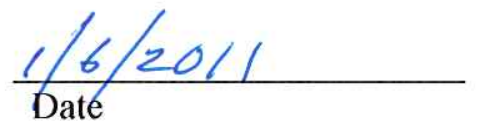





\section{TABLE OF CONTENTS}

LIST OF FIGURES

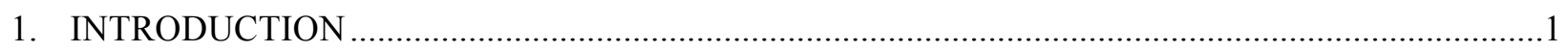

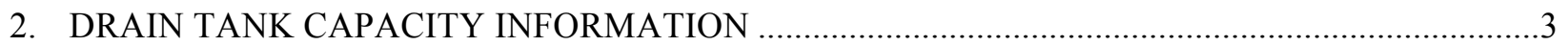

2.1 WATER INVENTORY FOR NORMAL DRAIN TANKS ….........................................

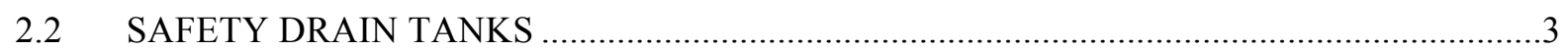

2.2.1 Water Inventory for the Safety Drain Tanks .......................................................

2.2.2 Analysis of the Calculations................................................................................6

2.2.3 Other Potential Liquid Volumes that May be Sent to the Safety Drain Tanks .............7

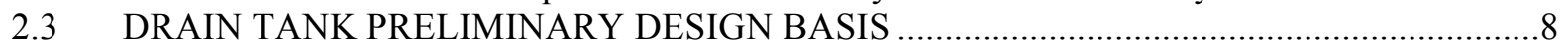

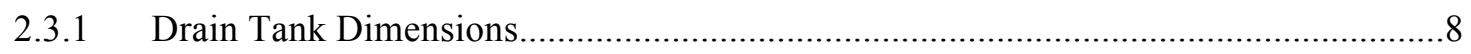

2.3.2 Development of Preliminary Design Basis for Drain Tanks...................................

3. ADDITIONAL INFORMATION FOR THE DRAIN TANK DESIGN BASIS ..............................11

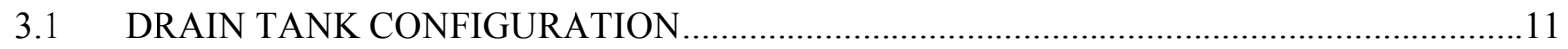

3.2 CONCEPTUAL APPROACH TO THE DRAIN TANK INSTALLATION ...........................12

3.2.1 Installation Coinciding with Construction of B2 Level (Both B2 Level and

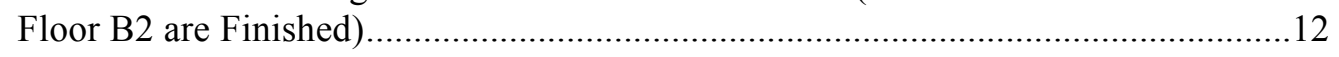

3.2.2 Delayed Installation after Construction of Ground Level .......................................14

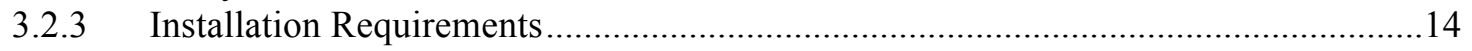

3.2.4 Construction of Ceiling on B2 that May Affect Installation Procedure......................15

3.2.5 ITER Organization Preferred Solution for the Drain Tank Installation .......................15

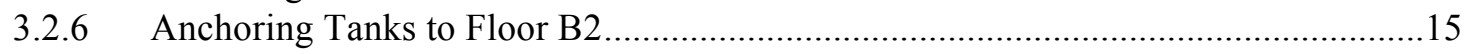

3.3 THERMOHYDRAULIC CONDITIONS FOR THE DRAIN TANK DESIGN FOR

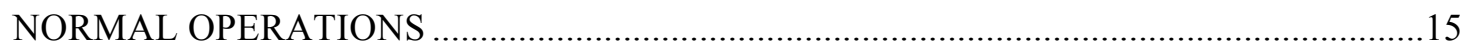

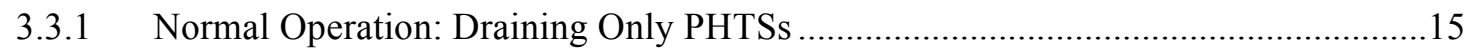

3.3.2 Normal Operation: Draining of Surplus Water Inventory During Water

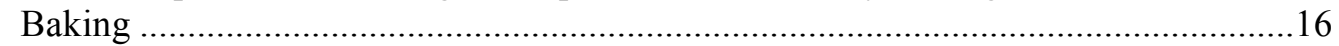

3.3.3 Normal Draining Operation: From Draining and Drying Operations .........................17

3.3.4 Analysis of Thermohydraulic Conditions for the Normal Operations of Drain

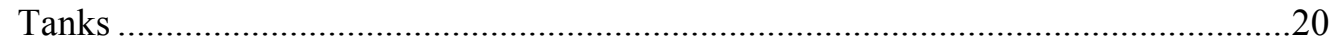

3.4 THERMOHYDRAULIC CONDITIONS FOR THE DRAIN TANK DESIGN FOR

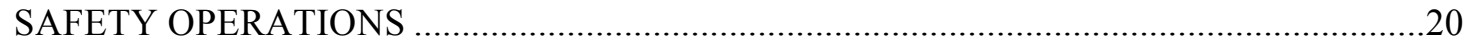

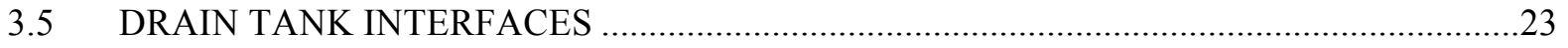

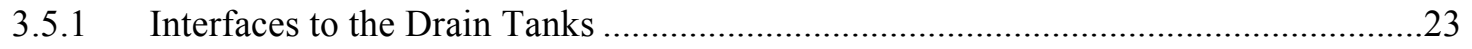

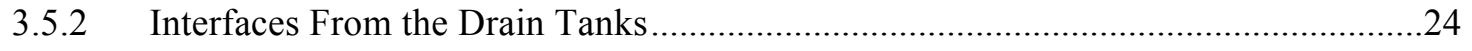

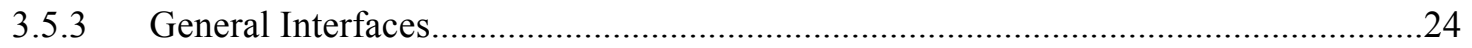

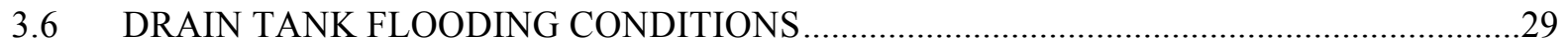

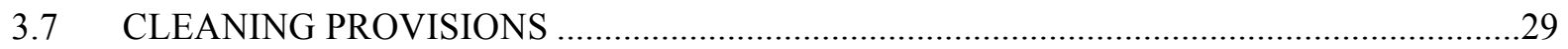

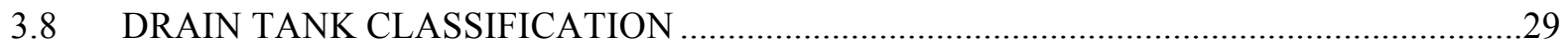

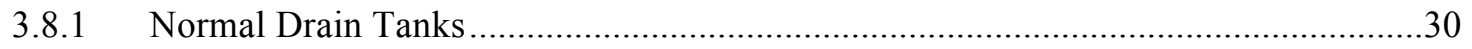




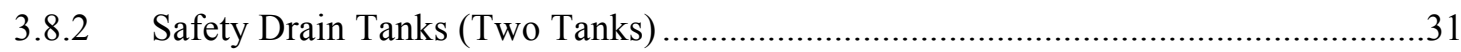

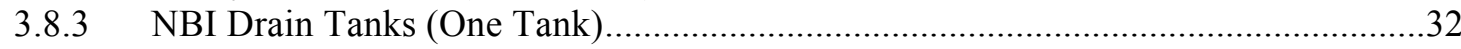

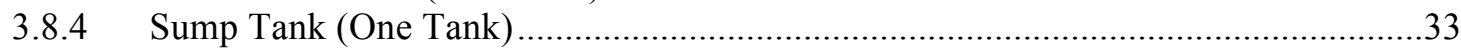

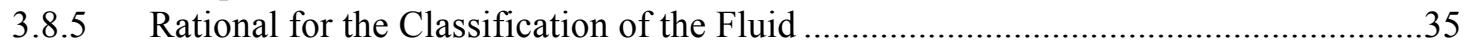

3.9 DRAIN TANK REQUIREMENTS FROM SYSTEM REQUIREMENTS

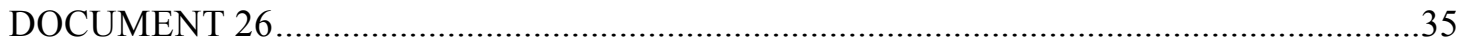

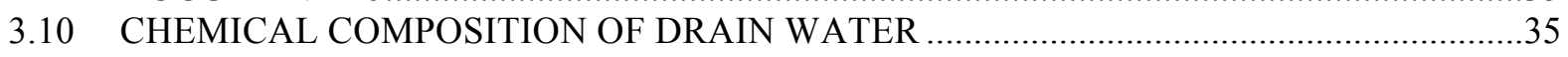

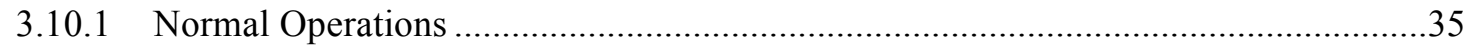

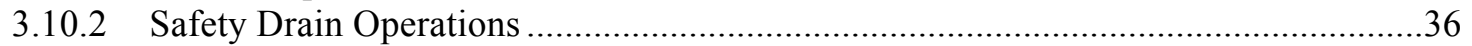

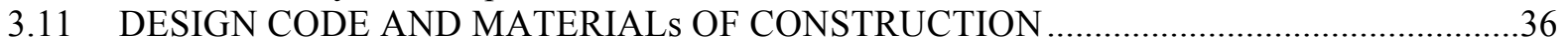

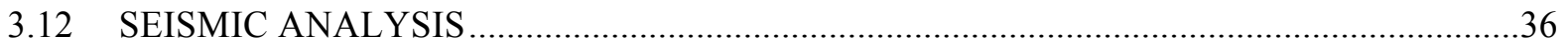

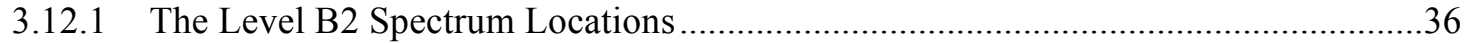

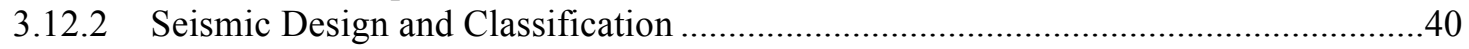

3.13 DRAIN TANK TEMPORARY STORAGE …....................................................................42

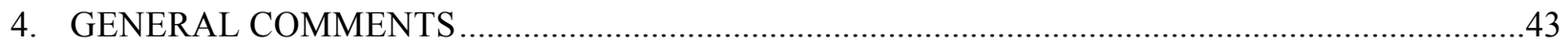

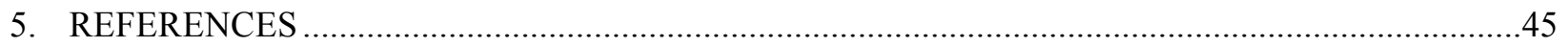

APPENDIX A. FUNCTIONAL REQUIREMENTS FOR THE SAFETY DRAIN TANKS ................. A-1

APPENDIX B. INTERFACES WITH THE DRAIN TANKS …......................................................

APPENDIX C. QUESTIONS ASKED BY AREVA ON INFORMATION FOR THE DESIGN

BASIS OF THE DRAIN TANKS ....................................................................... 


\section{LIST OF FIGURES}

Figure $\quad$ Page

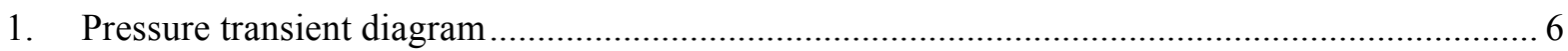

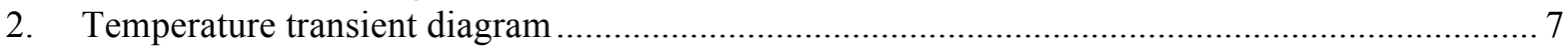

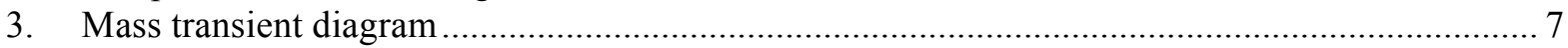

4. Drain tank configuration (safety drain tank size does not represent relative size) ...................... 11

5. Front view of drain tank area (safety drain tank size does not represent relative size)............... 11

6. Basic preliminary dimensions of the drain tank area (units: $\mathrm{m}$ ); height of building: $10.7 \mathrm{~m} \ldots \ldots .12$

7. Drain tank installation at level B2 with mezzanine construction ......................................... 13

8. Drain tank installation at level B2 with no mezzanine construction ...................................... 13

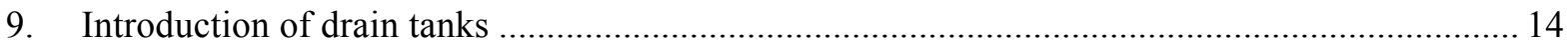

10. Draining of the PHTS isolated from the in-vessel component ................................................. 16

11. Excess water from water baking being drained into the corresponding drain tank .................... 17

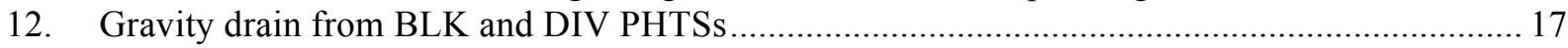

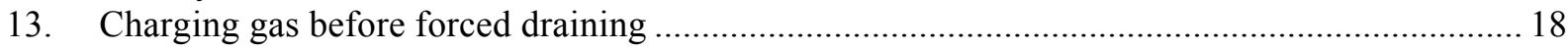

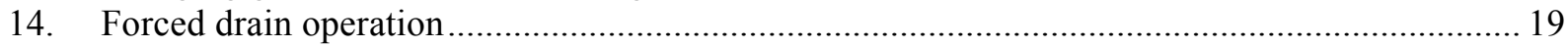

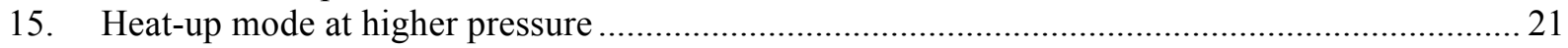

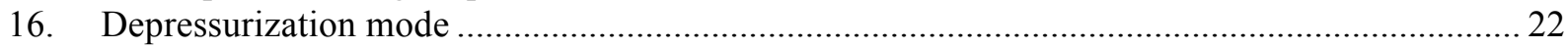

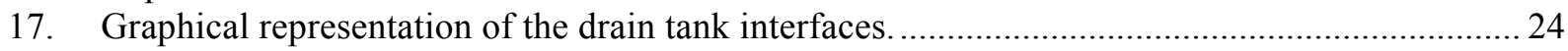

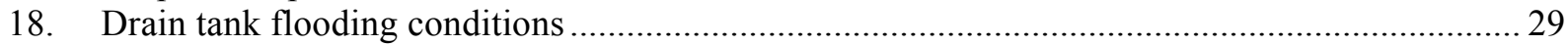

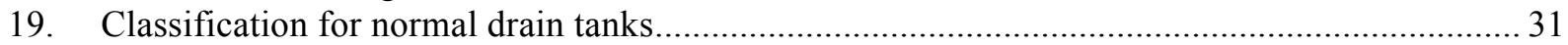

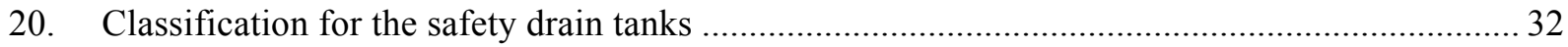

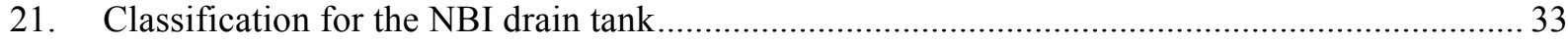

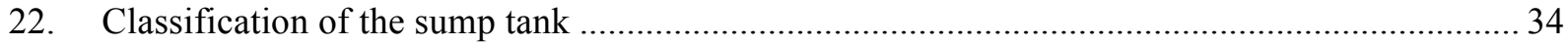

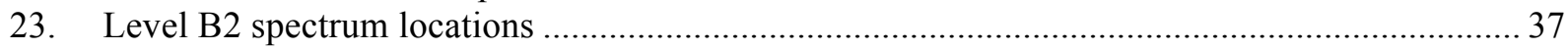

24. Floor response spectra (Node 46222), direction X broadened ................................................. 37

25. Floor response spectra (Node 46222), direction Y broadened .................................................. 38

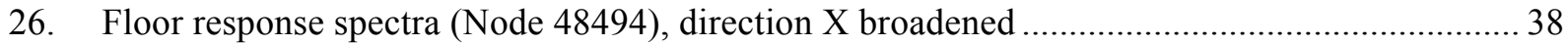

27. Floor response spectra (Node 48494), direction Y broadened .................................................... 39

28. Floor response spectra (Node 47862), direction $Z$ broadened.................................................. 39

29. Floor response spectra (Node 47842), direction $Z$ broadened.................................................. 40 



\section{LIST OF TABLES}

\section{Table}

1. Summary of normal operation water inventory in the Tokamak Cooling Water System .............. 3

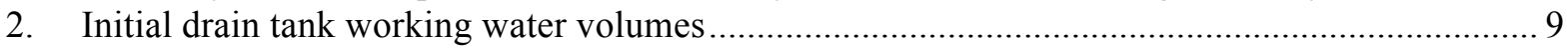

3. Extract of Table 1.4.1 from System Requirements Document 26 ..........................................23

4. Tokamak Cooling Water System drain tank interfaces ........................................................ 26

5. Tokamak Cooling Water System —Draining and Refilling System.......................................... 34

6. Coolant activation concentration for various ITER components and cooling systems ............... 35

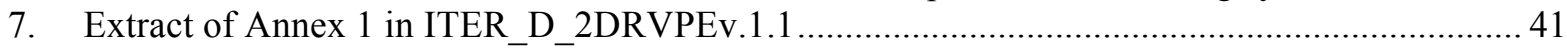





\section{ACRONYMS}

ACP

ASN

BLK

CATIA

CCFL

CVCS

DDD

DIV

DT

ELM

ESPN

FMEA

FW

ICD

IO

IS

LOCA

NBI

N-VDS

PBS

PCR

PHTS

RAMI

$\mathrm{SC}$

SRD

ST

TCWS

VV

VVPSS activated corrosion products

L'Autorité de sûreté nucléaire (French nuclear regulatory body)

Blanket

computer-graphics-aided three-dimensional interactive application counter-current-flow-limitation

Chemical and Volume Control System

Design Description Document

Divertor

drain tank

edge localized mode

Équipements Sous Pression Nucléaires

Failure Modes and Effects Analysis

First Wall

interface control document

ITER Organization

interface sheet

loss of coolant accident

Neutral Beam Injector

Normal Vent Detritiation System

Plant Breakdown Structure

Project Change Request

Primary Heat Transfer System

reliability, availability, maintainability, inspectability

seismic class

System Requirements Document

suppression tank

Tokamak Cooling Water System

Vacuum Vessel

Vacuum Vessel pressure suppression system 



\section{INTRODUCTION}

Tokamak Cooling Water System (TCWS) drain tanks (DTs) serve two functions: normal operation and safety operation. Normal DTs are used for regular maintenance operations when draining is necessary. Safety DTs are used to receive the water leaked into the Vacuum Vessel (VV) after an in-vessel loss of cooling accident (LOCA) event. The preliminary design of the DTs shall be based on the information provided by this document.

The capacity of the normal DTs is estimated based on the internal volume of in-vessel components [e.g., First Wall/Blanket (FW/BLK) and Divertor (DIV)], Neutral Beam Injector (NBI) components, and TCWS piping, heat exchangers, electric heaters, pump casing, pressurizers, and valves. Water volumes have been updated based on 2004 design information, changes adopted because of approved Project Change Requests (PCRs), and data verification by U.S. ITER. Two tanks will store water from normal draining operations of the FW/BLK and DIV Primary Heat Transfer Systems (PHTSs). One tank will store water from normal draining operations of the NBI PHTS.

The capacity of the safety DTs is based on analysis of a design-basis accident: ${ }^{1}$ a large leak from in-vessel components. There are two safety DTs that will receive water from a VV LOCA event and drainage from the $\mathrm{VV}$, as needed. In addition, there is one sump tank for the DIV that will be used for collecting drain water from the draining and drying processes and specifically for draining the DIV system as the DIV cassettes lines are at a lower elevation than the DT connection point.

Information documented in this report must be refined and verified during the preliminary design of the DTs, and there are several aspects to be considered to complete the preliminary design. Input to these design considerations is discussed in this report and includes, but is not limited to, water inventory; operating procedures/maintenance; Failure Modes and Effects Analysis (FMEA); tank layout and dimensions, including design margin; classification under French Nuclear Pressure Directives, Équipements Sous Pression Nucléaires (ESPN); and adaptations for construction. 



\section{DRAIN TANK CAPACITY INFORMATION}

\subsection{WATER INVENTORY FOR NORMAL DRAIN TANKS}

Normal DTs are provided to accommodate storage of coolant during maintenance and inspection, excess coolant from the PHTSs because of water volume expansion during baking operations, and residual coolant from forced draining and drying. The volume of water to be stored in these tanks is based on the volume of water contained in the following items for each PHTS.

- In-vessel VV component water holdup (FW/BLK and DIV)

- NBI water holdup

- $\quad$ PHTS piping and equipment water holdup

○ Piping

○ Pump

- Heat Exchanger

- Pressurizer

The water inventory is estimated based on the conceptual design, which was modified after the conceptual design review by design changes that were approved through PCRs as described below. Important changes to the 2004 baseline reduced the water volume and required DT capacity.

- PCR 154 resulted in redesign of heat exchangers moving the high-pressure, radioactive water from the shell side to the tube side of each heat exchanger. This design change resulted in the internal volume being reduced to about $1 / 3$ of the original volume. ${ }^{2}$

- PCR 190 resulted in redesign of the VV PHTS. One pipe loop was eliminated and the size of the heat exchanger was reduced. PHTS equipment such as pressurizers and pumps was resized. ${ }^{3,4}$

- $\quad$ PCR 273 resulted in redesign of the FW/BLK and DIV PHTS. Four piping loops were combined in the vault, and one pair of heat exchangers and a pump and one heater were added to meet reliability, availability, maintainability, inspectability (RAMI) requirements.

Table 1 indicates the different water volumes required to size the DTs, the source of information, and a qualification of the information. Numbers in Table 1 have been rounded to the next integer.

\subsection{SAFETY DRAIN TANKS}

The purpose of the safety DTs is to store the inventory of water that results from the design basis LOCAs that result in a large leak into the VV. Two safety DTs were designed to serve this purpose- the design is based on an analysis done by the ITER Organization (IO) Safety Group. ${ }^{5}$ These tanks will also be used to store water from VV normal operations. IO has issued the document "Functional Requirements for the Safety Drain Tanks" that was approved by IO and is included in Appendix A of this document.

Table 1. Summary of normal operation water inventory in the Tokamak Cooling Water System

\begin{tabular}{|l|l|c|l|l|}
\hline Item & \multicolumn{1}{|c|}{ Item description } & $\begin{array}{c}\text { Internal } \\
\text { volume } \\
\left(\mathbf{m}^{\mathbf{3}}\right)\end{array}$ & 84 & $\begin{array}{c}\text { Source of } \\
\text { information } \\
\text { (Table 3.1.1-1) }\end{array}$ \\
\hline 1. & BLK in-vessel component & 71 & After PCR 273 & $\begin{array}{c}\text { Qualification of } \\
\text { information } \\
\text { values }\end{array}$ \\
\hline 2. & BLK piping, Vault Area & $\begin{array}{l}\text { Recalculated by U.S. ITER } \\
\text { including PCR 273 }\end{array}$ \\
\hline
\end{tabular}




\begin{tabular}{|c|c|c|c|c|}
\hline Item & Item description & $\begin{array}{c}\text { Internal } \\
\text { volume } \\
\left(\mathbf{m}^{3}\right)\end{array}$ & $\begin{array}{l}\text { Source of } \\
\text { information }\end{array}$ & $\begin{array}{l}\text { Qualification of } \\
\text { information }\end{array}$ \\
\hline 3. & $\begin{array}{l}\text { BLK/DIV piping, Vault Area, } \\
\text { spare }\end{array}$ & 18 & After PCR 273 & $\begin{array}{l}\text { Recalculated by U.S. ITER } \\
\text { including PCR } 273\end{array}$ \\
\hline 4. & $\begin{array}{l}\text { Upper Pipe Chase BLK ring } \\
\text { manifold }\end{array}$ & 60 & 2004 design & $\begin{array}{l}\text { U.S. ITER TCWS recalculated } \\
\text { values }\end{array}$ \\
\hline 5. & $\begin{array}{l}\text { Upper Pipe Chase BLK branch } \\
\text { piping }\end{array}$ & 28 & 2004 design & $\begin{array}{l}\text { U.S. ITER TCWS recalculated } \\
\text { values }\end{array}$ \\
\hline 6. & BLK heat exchanger & 54 & PCR 154, Washington Group & $\begin{array}{l}\text { Recalculated by U.S. ITER } \\
\text { including PCR } 273\end{array}$ \\
\hline 7. & $\begin{array}{l}\text { Spare BLK/DIV heat exchanger, } \\
\text { Vault Area }\end{array}$ & 18 & $\begin{array}{l}2004 \text { design, PCR } 154, \\
\text { Washington Group }\end{array}$ & $\begin{array}{l}\text { Recalculated by U.S. ITER } \\
\text { including PCR } 273\end{array}$ \\
\hline 8. & BLK pump casing & 1 & 2004 design & $\begin{array}{l}\text { Recalculated by U.S. ITER } \\
\text { including PCR } 273\end{array}$ \\
\hline 9. & $\begin{array}{l}\text { BLK/DIV pump casing, Vault } \\
\text { Area, spare }\end{array}$ & 1 & 2004 design & $\begin{array}{l}\text { Recalculated by U.S. ITER } \\
\text { including PCR } 273\end{array}$ \\
\hline 10. & BLK pressurizer & 50 & $\begin{array}{l}\text { SADL V5.2.6 } \\
\text { (Table 3.1.3-1) }\end{array}$ & $\begin{array}{l}\text { Assumed to be similar to current } \\
\text { design }\end{array}$ \\
\hline 11. & BLK valves & 3 & $2004 \operatorname{design}^{a}$ & $\begin{array}{l}\text { Assumed to be similar to current } \\
\text { design }\end{array}$ \\
\hline 12. & DIV in-vessel component & 23 & $\begin{array}{l}\text { SADL V5.2.6 } \\
\text { (Table 3.2.1-1) }\end{array}$ & $\begin{array}{l}\text { Assumed to be similar to current } \\
\text { design }\end{array}$ \\
\hline 13. & DIV piping, Vault Area & 24 & After PCR 273 & $\begin{array}{l}\text { Recalculated by U.S. ITER } \\
\text { including PCR } 273\end{array}$ \\
\hline 14. & $\begin{array}{l}\text { DIV Lower Pipe Chase ring } \\
\text { manifold }\end{array}$ & 17 & 2004 design & $\begin{array}{l}\text { U.S. ITER TCWS recalculated } \\
\text { values }\end{array}$ \\
\hline 15. & $\begin{array}{l}\text { DIV Lower Pipe Chase branch } \\
\text { piping }\end{array}$ & 20 & 2004 design & $\begin{array}{l}\text { U.S. ITER TCWS recalculated } \\
\text { values }\end{array}$ \\
\hline 16. & DIV heat exchanger & 18 & PCR 154, Washington Group & $\begin{array}{l}\text { Recalculated by U.S. ITER } \\
\text { including PCR } 273\end{array}$ \\
\hline 17. & DIV pump casing & 1 & 2004 design & $\begin{array}{l}\text { Recalculated by U.S. ITER } \\
\text { including PCR } 273\end{array}$ \\
\hline 18. & DIV pressurizer & 23 & \begin{tabular}{|l|} 
SADL V5.2.6 \\
(Table 3.2.3-3) \\
\end{tabular} & $\begin{array}{l}\text { Assumed to be similar to current } \\
\text { design }\end{array}$ \\
\hline 19. & DIV valves & 1 & 2004 design & $\begin{array}{l}\text { Assumed to be similar to current } \\
\text { design }\end{array}$ \\
\hline 20. & $\begin{array}{l}\text { VV, port stub, port stub } \\
\text { extension }\end{array}$ & 235 & DDD1.5 Vacuum Vessel ${ }^{\mathbf{c}}$ & DDD1.5 Vacuum Vessel ${ }^{\mathbf{c}}$ \\
\hline 21. & VV PHTS piping & 36 & PCR 190 & $\begin{array}{l}\text { U.S. ITER TCWS recalculated } \\
\text { values }\end{array}$ \\
\hline 22. & VV PHTS heat exchanger & 15 & Current information & $\begin{array}{l}\text { Current information U.S. ITER } \\
\text { TCWS recalculated values }\end{array}$ \\
\hline 23. & VV PHTS heat exchanger & 15 & Current information & $\begin{array}{l}\text { Current information U.S. ITER } \\
\text { TCWS recalculated values }\end{array}$ \\
\hline 24. & VV PHTS safety heat exchanger & 1 & Current information & $\begin{array}{l}\text { U.S. ITER TCWS recalculated } \\
\text { values }\end{array}$ \\
\hline
\end{tabular}




\begin{tabular}{|c|c|c|c|c|}
\hline Item & Item description & $\begin{array}{c}\text { Internal } \\
\text { volume } \\
\left(\mathbf{m}^{\mathbf{3}}\right) \\
\end{array}$ & $\begin{array}{l}\text { Source of } \\
\text { information }\end{array}$ & $\begin{array}{l}\text { Qualification of } \\
\text { information }\end{array}$ \\
\hline 25. & VV PHTS pump casing & 1 & 2004 design & $\begin{array}{l}\text { Assumed to be similar to current } \\
\text { design }\end{array}$ \\
\hline 26. & $\begin{array}{l}\text { VV piping after PCR } 190 \text { Upper } \\
\text { Pipe Chase ring manifold }\end{array}$ & 8 & PCR 190 & $\begin{array}{l}\text { U.S. ITER TCWS recalculated } \\
\text { values }\end{array}$ \\
\hline 27. & $\begin{array}{l}\text { VV piping after PCR } 190 \text { Upper } \\
\text { Pipe Chase branch piping }\end{array}$ & 10 & PCR 190 & $\begin{array}{l}\text { U.S. ITER TCWS recalculated } \\
\text { values }\end{array}$ \\
\hline 28. & $\begin{array}{l}\text { VV piping after PCR } 190 \text { Lower } \\
\text { Pipe Chase ring manifold }\end{array}$ & 8 & PCR 190 & $\begin{array}{l}\text { U.S. ITER TCWS recalculated } \\
\text { values }\end{array}$ \\
\hline 29. & $\begin{array}{l}\text { VV piping after PCR } 190 \text { Lower } \\
\text { Pipe Chase branch piping }\end{array}$ & 5 & 2004 Design, PCR 190 & $\begin{array}{l}\text { U.S. ITER TCWS recalculated } \\
\text { values }\end{array}$ \\
\hline 30. & VV pressurizer & 20 & Current information & $\begin{array}{l}\text { Current information U.S. ITER } \\
\text { TCWS recalculated values }\end{array}$ \\
\hline 31. & NBI internal components & 10 & 2004 design $^{b}$ & $\begin{array}{l}\text { U.S. ITER TCWS recalculated } \\
\text { values }\end{array}$ \\
\hline 32. & NBI PHTS, inside vault & 56 & 2004 design & $\begin{array}{l}\text { U.S. ITER TCWS recalculated } \\
\text { values }\end{array}$ \\
\hline 33. & NBI piping outside vault & 30 & 2004 design & $\begin{array}{l}\text { U.S. ITER TCWS recalculated } \\
\text { values }\end{array}$ \\
\hline 34. & $\begin{array}{l}\text { Total working volume for DIV } \\
\text { and } \operatorname{BLK}\left(\mathrm{m}^{3}\right)\end{array}$ & 515 & & \\
\hline 35. & $\begin{array}{l}\text { Total working volume for } \mathrm{VV} \\
\left(\mathrm{m}^{3}\right)\end{array}$ & 354 & & \\
\hline 36. & $\begin{array}{l}\text { Total working volume for NBI } \\
\left(\mathrm{m}^{3}\right)\end{array}$ & 96 & & \\
\hline
\end{tabular}

${ }^{a}$ N26 MD 30 99-11-17 W 0.3 Design Basis on Primary First Wall and Blanket PHTS of ITER-FEAT.

${ }^{b}$ DDD 1.5 Vacuum Vessel, 22 FPN2, October 13, 2009.

${ }^{\mathfrak{c}}$ DDD1.5 Vacuum Vessel, G15 DDD 04 01-06-25 R 0.1

\subsubsection{Water Inventory for the Safety Drain Tanks}

The safety DTs are maintained in a partially evacuated condition (about $4 \mathrm{kPa}$ ) during plasma operation and are designed for washout after the contaminated liquid is transferred to the radioactive waste building. The VV coolant will be drained three times in the lifetime of the project, and the drained water will be stored in the safety DTs.

The IO Safety Group calculated the volume and thermal parameters of water spilled during a LOCA and the subsequent volume that must be drained from the VV.

This analysis establishes the basis for the safety DT capacity. Leonid Topilski, ${ }^{6,7}$ IO Safety Group, performed these calculations using the MELCOR code.

Topilski's study considered that water drains from the lowest point of the DIV ports $(-5.6 \mathrm{~m})$ through eight pipes, each $50 \mathrm{~mm}$ in diameter and $2 \mathrm{~m}$ long (of nine valves in nine pipes, one valve is assumed failed to open), into the drain collector and then through the drain pipe (Din $=300 \mathrm{~mm}$ ) to the DT. The drain pipe is attached to the DT at elevation of $-11.0 \mathrm{~m}$. In the accident considered, it was assumed that water is spilled in the VV from three FW/BLK loops (total water hold-up $383 \mathrm{~m}^{3}$ [or $\sim 360$ tons] and total 
break area $0.02 \mathrm{~m}^{2}$ ) and from the DIV loop (water hold-up $141 \mathrm{~m}^{3}$ [or $\sim 132.5$ tons] and break area $0.000157 \mathrm{~m}^{2}-1$ cooling tube). Transient results for pressure are shown in Fig. 1, temperature transients are shown in Fig. 2, and mass transients are shown in Fig. 3. Appendix A describes the safety DT capacity calculated by the IO Safety Group.

\subsubsection{Analysis of the Calculations}

The design basis accidents establish that the maximum pressure in the DT is $80 \mathrm{kPa}(0.080 \mathrm{MPa})$ and the maximum temperature is $94^{\circ} \mathrm{C}$. Water mass drained into the DT is about 330 tons. When a LOCA occurs inside the VV with 490 tons of water contained in four cooling loops comprising three FW/BLK loops and one DIV loop, about 440 tons are postulated to be spilled into the VV. About 110 tons of coolant turns to steam and is collected in the VV pressure suppression system (VVPSS) tank. The analysis establishes the basis for 330 tons of water to be drained to the safety DTs during this design basis accident. Calculations were made using the MELCOR code that carries prediction uncertainties of about $10 \%-15 \%$ that are not included in the results of 330 tons.

Pressure in VV, suppression tank (ST) and drain tank (DT)

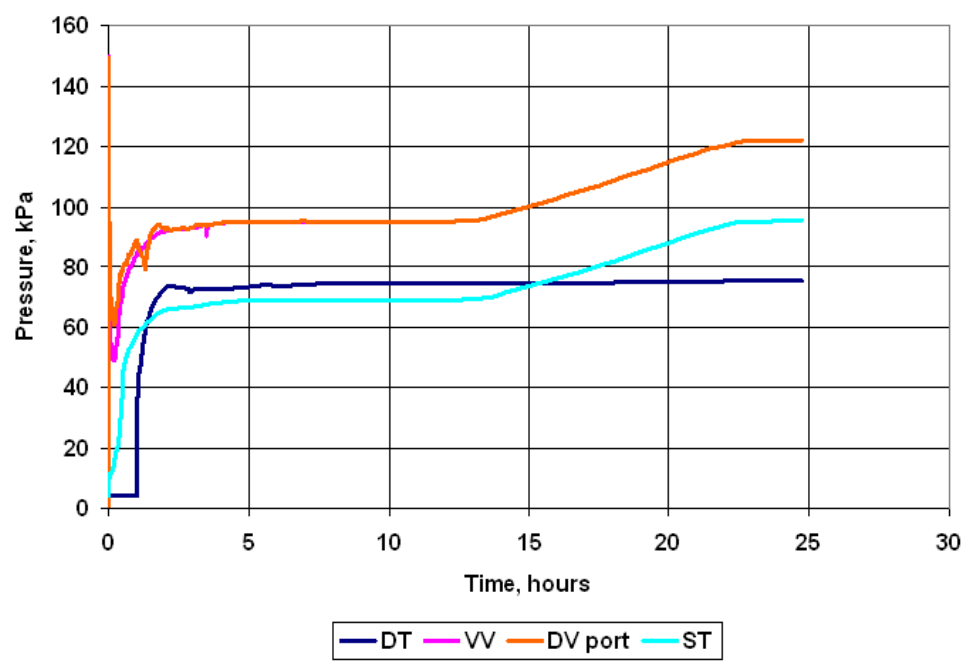

Fig. 1. Pressure transient diagram. 


\section{Vapor temperature}

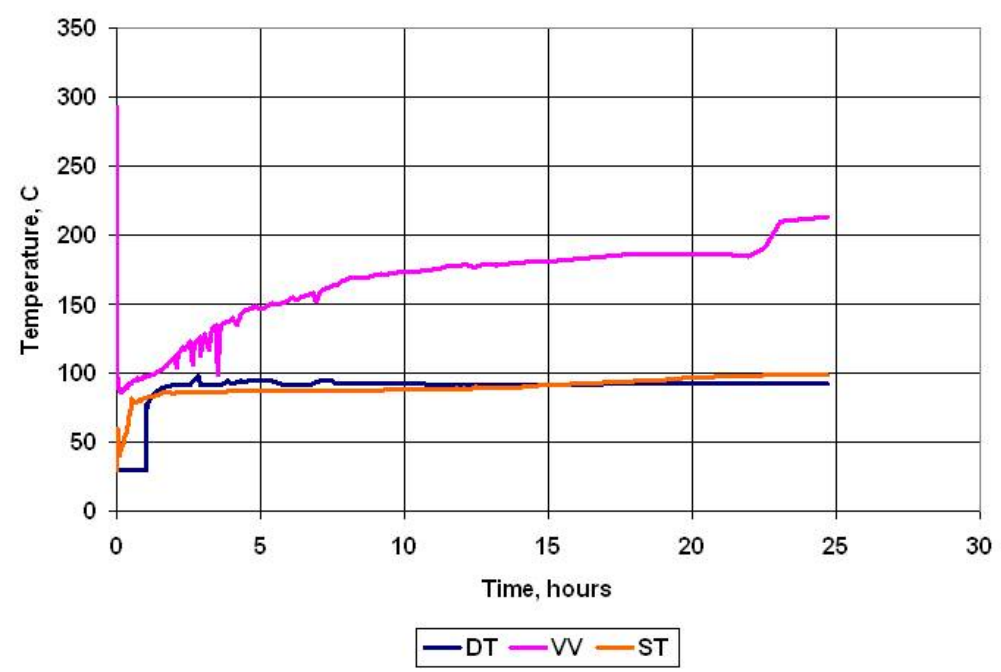

Fig. 2. Temperature transient diagram.

Coolant mass in DT, drain pipe, DV port and transported in ST

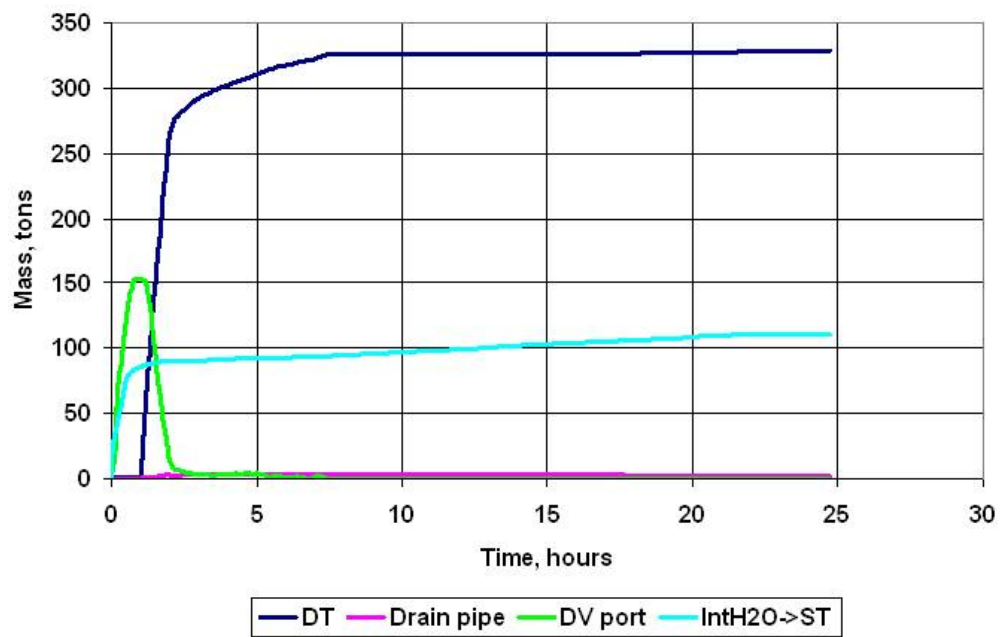

Fig. 3. Mass transient diagram.

\subsubsection{Other Potential Liquid Volumes that May be Sent to the Safety Drain Tanks}

Additional water volumes could be sent to the safety DTs according to conversations with IO. After a LOCA event the water collected in the VV will be sent to the safety DTs via the safety drain lines after several hours have elapsed.

After a LOCA event inside the $\mathrm{VV}$, the steam will be directed via two rupture disks in series to the VVPSS tank. However, after the event has occurred, the operator could decide to transfer the water collected in the VV to the safety DTs by gravity. This water, after local reprocessing to eliminate heavy radioactive dust with codeposited tritium, will be sent to the Radwaste Building. The excess water collected in the VVPSS tank should also be channeled to the Radwaste Building via the same outlet pipe 
from the DT room. According to the project requirements, this water could be discharged in the DT room for reprocessing before sending to the Radwaste Building. The emergency DTs have lower volume than the VVPSS tank; therefore there is no need for temporary storage. This waste water may have solids in suspension that will stay in the safety DT for some time. If this time is long (it has not been determined yet by IO operations), the solids could settle at the bottom of the tank with the potential for clogging the tank exit pipe. Other types of waste water collected in the sump system of the vault will be directly sent to the Radwaste Building via a dedicated pump in the pit underneath the Lower Pipe Chase. An NBI spill may be routed to the safety drain tanks and from there to the Radwaste Building.

As described in the previous paragraph, there is the possibility of having solids in suspension with the attendant problems. The potential volumes of these waste waters will not be a problem for the safety DTs; however, this information should be considered when designing the safety DTs to avoid these problems. AREVA is expected to proposed design actions for this potential required feature for U.S. ITER to make decisions.

\subsection{DRAIN TANK PRELIMINARY DESIGN BASIS}

\subsubsection{Drain Tank Dimensions}

Water working volume estimates for the normal operation FW/BLK and DIVDTs in Sect. 2.1 establish the basis for $515 \mathrm{~m}^{3}$ of water storage space. The nitrogen space volume that will exist above the high level surface should be considered for the tank design. AREVA will provide design safety factors to determine the tank design volume based on best engineering practice adhering to the appropriate codes.

The VV will be drained only three times over the lifetime of the project. The first time will be during commissioning and testing; the second, after nonradioactive operations during testing before radioactive operations; and the third, during decommissioning. The safety DTs will not be in use during these three maintenance periods. There is no need for separate VV DTs; the VV PHTS will be drained to the safety DTs. From Table 1, item 35, the working volume of water corresponding to the VV PHTS, piping, and invessel components is about $354 \mathrm{~m}^{3}$, which can be contained in the safety DTs. ${ }^{8,9}$ The water storage needs for the NBI are $96 \mathrm{~m}^{3}$.

The DIV is connected to a DT, which has a sump tank to assist draining and a sump pump to move the water because the level of the DIV cassettes is below the gravity drain line. Sump tank and pump are provided to transfer the water between normal DTs providing a flexible design that allows options for managing water storage during maintenance. This sump tank is also used to collect drain water. IO would like to consider only one sump tank of $4 \mathrm{~m}^{3}$ connected to the drying system. During the gravity drain of the VV there is a risk of insufficient height from the bottom of the Lower Pipe Chase to the level in the DT to permit a full drainage. Therefore the drain line from the VV can connect to the same sump tank by using an isolation valve. Thus, there will be one sump tank that can be used for both DIV and VV draining procedures. After each procedure the sump tank should be washed.

The diameter of all the tanks will be calculated to accommodate the DTs in the allocated space in the basement level of the Tokamak Building. AREVA will determine the DT dimensions based on the expected storage water volume and appropriate engineering practices. Table 2 indicates the number of tanks and their expected volumes.

The draining tanks (normal and safety operations) may be fabricated with the same dimensions. Although Table 2 indicates that these tanks have different volumes, economics of having only one engineering set for the four tanks may be advantageous from a value engineering stand point. This will be determined by AREVA. 
Table 2. Initial drain tank working water volumes

\begin{tabular}{|l|c|c|}
\hline & $\begin{array}{c}\text { Number of } \\
\text { tanks }\end{array}$ & $\begin{array}{c}\text { Working water volume } \\
\text { per tank } \mathbf{( m}^{\mathbf{3}} \mathbf{)}\end{array}$ \\
\hline FW/BLK and DIV Normal DTs & 2 & 258 \\
\hline $\begin{array}{l}\text { FW/BLK and DIV/VV Safety } \\
\text { DTs }\end{array}$ & 2 & $215^{a}$ \\
\hline NBI Tank & 1 & 96 \\
\hline Sump Tank DIV/BLK & 1 & 4 \\
\hline
\end{tabular}

${ }^{a}$ Per Appendix A, "Functional Requirements for the Safety Drain Tanks," the total design volume for the safety DTs should be calculated as $330 \mathrm{~m}^{3}+30 \%$ excess capacity.

\subsubsection{Development of Preliminary Design Basis for Drain Tanks}

Several aspects must be considered to complete the preliminary design of the DTs. Information documented in this report must be refined and verified during the preliminary design of the DTs. Input to these design considerations is discussed in this report and includes, but is not limited to, water inventory; operating procedures; FMEA; tank layout and dimensions, including design margin; classification under ESPN; and adaptations for construction.

Equipment sizing (heat exchangers, pump casings, and pressurizers, as a minimum) and threedimensional models of piping equipment layout will be completed by AREVA during preliminary design.

Operating procedures are evaluated to establish thermohydraulic requirements for the normal DTs. The FMEA, to be completed by AREVA, will evaluate system failure modes and establish whether DT thermohydraulic requirements encompass the design features needed to mitigate system failure modes. For example, are failure modes identified where the water to be drained cannot be cooled to $100^{\circ} \mathrm{C}$ before draining is required?

DTs are categorized as nuclear pressure equipment under ESPN. IO is responsible for equipment classification under ESPN and has documented the classification for the normal and safety DTs.

Sound engineering principles will be applied to DT design during the preliminary design. Tank capacities proposed in Table 2 are the best estimate before the preliminary design is completed and are to be used as a guide for the preliminary design. Changes to these values, especially the NBI tank, are possible-final dimensions must be established during preliminary design. 



\section{ADDITIONAL INFORMATION FOR THE DRAIN TANK DESIGN BASIS}

\subsection{DRAIN TANK CONFIGURATION}

The DTs of the FW/BLK, DIV, and NBI PHTSs are vertical type. These five tanks will be installed in the north part of B2 level of the Tokamak building as illustrated in Fig. 4. Figure 5 illustrates the front view of the DT area showing the position of a mezzanine where the VV PHTS equipment will be located.

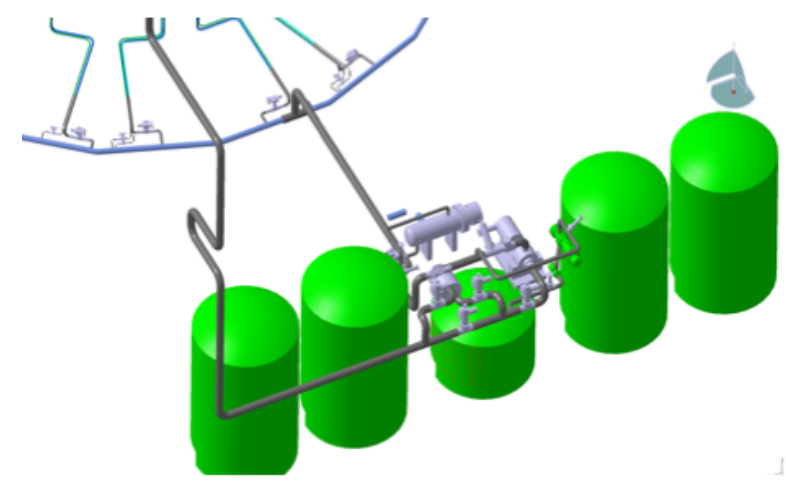

Fig. 4. Drain tank configuration (safety drain tank size does not represent relative size).

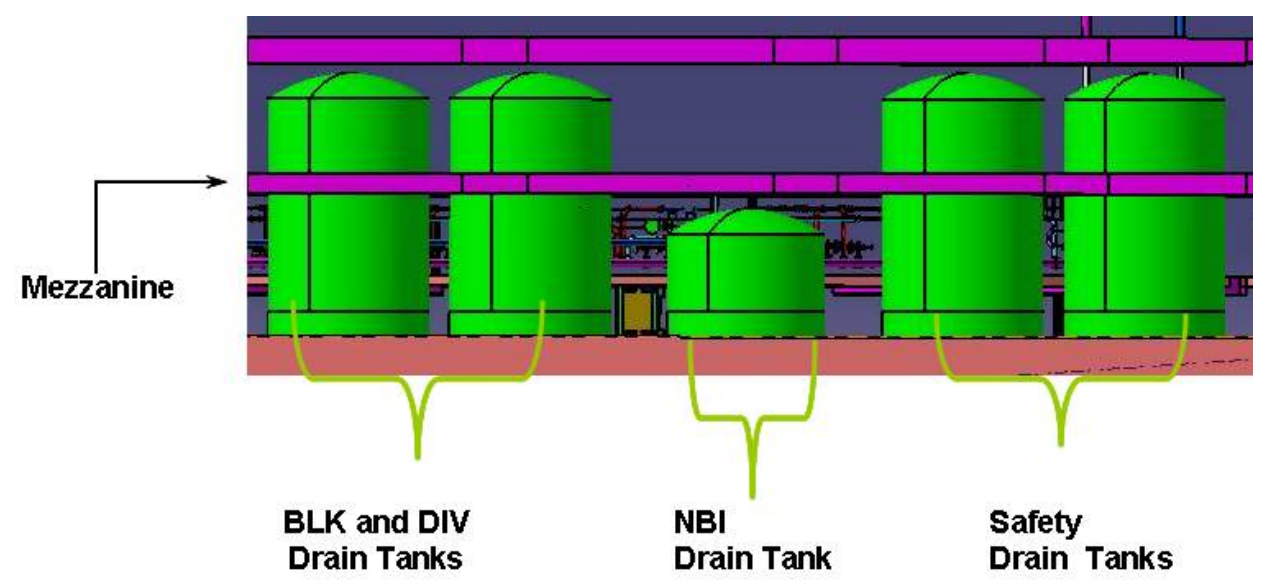

Fig. 5. Front view of drain tank area (safety drain tank size does not represent relative size).

For this DT configuration, three refilling pumps are necessary: one for the FW/BLK and DIV normal DTs, one for the NBI DT, and one for the safety DTs. Figure 6 indicates preliminary measurements for the DT area. AREVA will have to refine these measurements based on the computer-graphics-aided three-dimensional interactive application (CAD software) (CATIA) drawings. Figure 6 also shows the sump tank. 


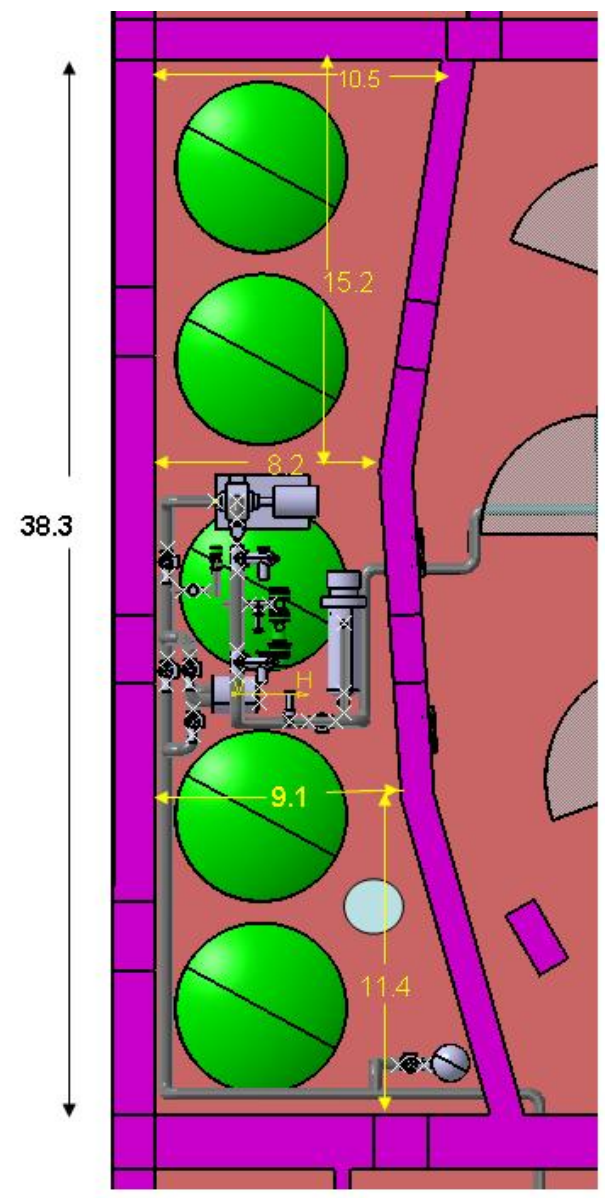

Fig. 6. Basic preliminary dimensions of the drain tank area (units: $\mathrm{m}$ ); height of building: $10.7 \mathrm{~m}$.

\subsection{CONCEPTUAL APPROACH TO THE DRAIN TANK INSTALLATION}

The size of the DTs will require that the installation be performed during the construction of the building. Several installation scenarios must be considered that depend on the delivery date of the tanks. The two general scenarios are (1) installation coinciding with the construction of the ground level of the building or (2) delayed installation after the B1 level concrete is finished.

\subsubsection{Installation Coinciding with Construction of B2 Level (Both B2 Level and Floor B2 are Finished)}

This is the preferred and most conservative option, and it assumes that the tanks will be in place when the B2 level is finished. There are two possible variations on this installation scenario, and the decision on the installation procedure will depend on whether the construction of the mezzanine on the DT area is completed. The possibility of combining the cooling needs of the edge localized mode (ELM) coils with the FW/BLK and DIV PHTSs is being studied under PCR-273. This decision, in addition to a thorough analysis of the available vault space and safety considerations, will determine whether the VV PTHS will be installed on top of the mezzanine or in the vault area. 
Mezzanine is constructed. This option dictates that the VV PTHS cannot be installed in the vault area, and the installation of the DTs needs to follow a specific sequence. Figure 7 illustrates the three phases of installation for this option. First, two of the large tanks are moved into place using IO moving platforms; second, the mezzanine is constructed; and third, the NBI and the other two large tanks are moved into place. This option requires careful coordination between IO and U.S. ITER related to scheduling tank delivery and construction of the building.

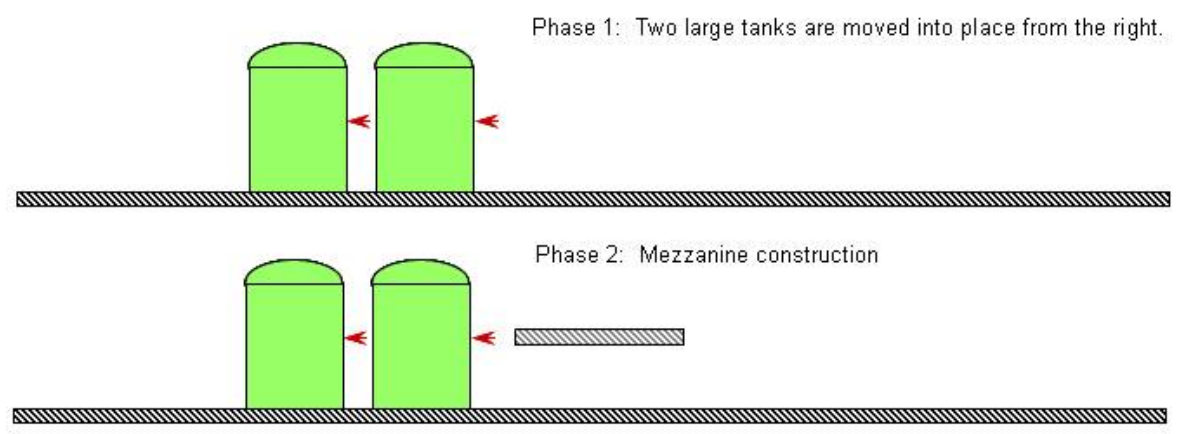

Phase 3: NBl and the two other large tanks are moved into place from the right.

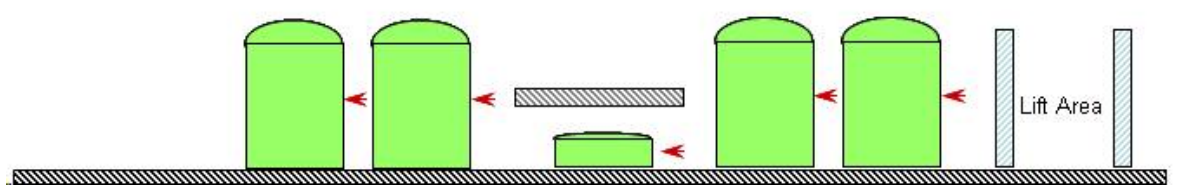

Fig. 7. Drain tank installation at level $B 2$ with mezzanine construction.

Mezzanine is not constructed. This is a straightforward option where the DTs are moved into place one after the other as illustrated in Fig. 8.

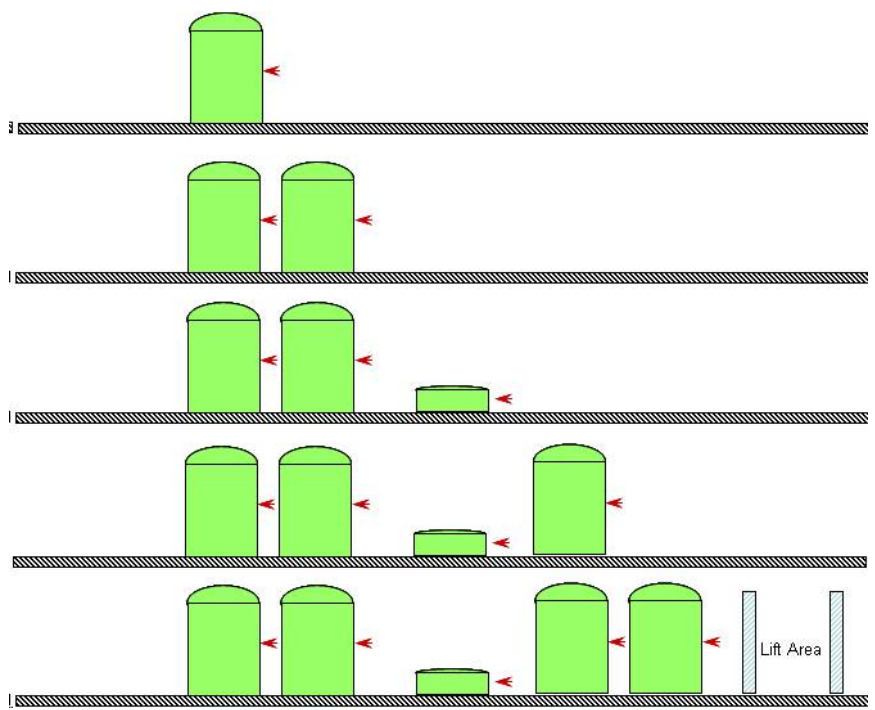

Fig. 8. Drain tank installation at level B2 with no mezzanine construction. 


\subsubsection{Delayed Installation after Construction of Ground Level}

This option assumes that level L1 is finished. The current thinking is that the installation of five vertical tanks can be carried out by a mobile crane, which could be located outside and to the north of the building. The transportation path will be through temporary openings in the slab of B1 level, the slab of L1 level, and perhaps the slab of L3 level (if necessary, depending on the timetables for building construction and equipment delivery). These five tanks will be placed in position by an up-to-down method.

For the installation of DTs, there are several options. One is to use the elevator well, which is $11.5 \mathrm{~m}$ by $6.98 \mathrm{~m}$. The tanks will be lifted from their temporary storage area by a mobile crane and lowered to the B2 level through the elevator well. With the help of an air pallet and a monorail hoist, the tanks will be ground transported and placed in final position as depicted in Fig. 9. If this approach is accepted, the DTs could potentially be delivered at a later date. There are also two variations on the delayed installation scenario that depend on the need to construct the mezzanine.

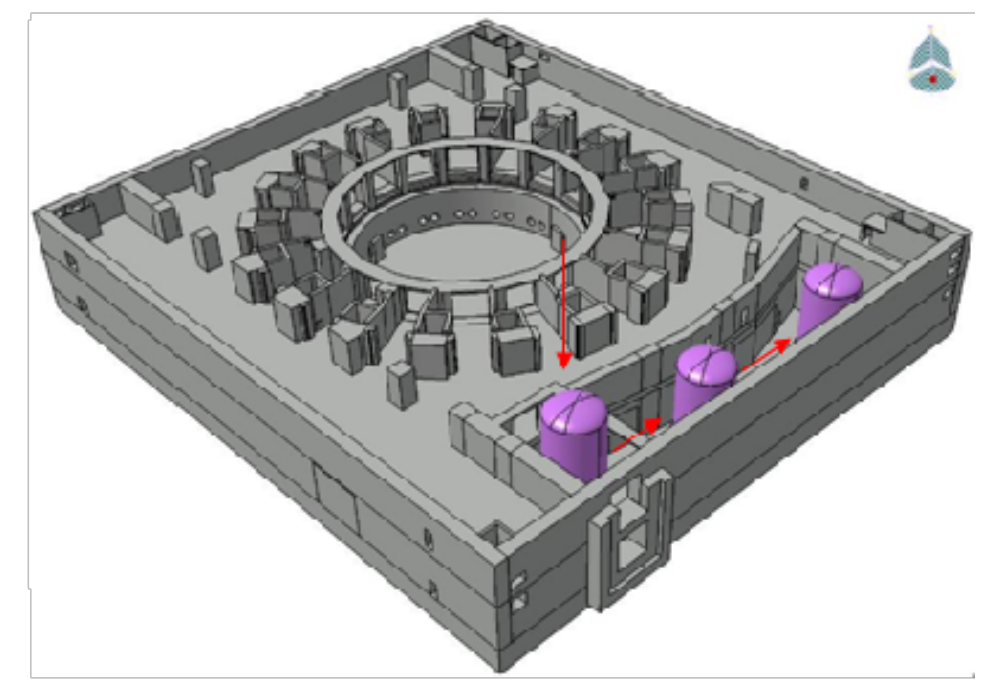

Fig. 9. Introduction of drain tanks.

\subsubsection{Installation Requirements}

After a DT is lifted vertically through the elevator shaft to the B2 level, the tanks will be moved horizontally using air pallets that will be provided by IO during the installation process. Temporary brackets for attaching air pads to the tanks will be provided by U.S. ITER. Specifications for the temporary brackets will come from IO. Other general requirements for the DTs are

- DTs should include support skirts at their bases,

- DTs are to be provided with lifting lugs to permit the crane to lift and lower the tanks in their vertical position to the $\mathrm{B} 2$ level,

- DT design should accommodate access gap in skirts to underside of tank, 
- DT support skirts should be able to be lifted in the elevator shaft if necessary, and

- overall DT height (with the air transport pads) should be compatible with the net height in the room $(10.7 \mathrm{~m})$.

\subsubsection{Construction of Ceiling on B2 that May Affect Installation Procedure}

The latest information from the IO Construction Group indicated that the ceiling on B2 has to be finished before the DTs are positioned on B2. This information will have to be considered in the design.

\subsubsection{ITER Organization Preferred Solution for the Drain Tank Installation}

Based on the latest information from the IO Construction Group, the sequence for the DT installation would be (1) finish B2 floor, (2) finish the ceiling on B2 floor, (3) install the two normal operation DTs, (4) construct the mezzanine, (5) install the NBI DT, and (6) install the safety DTs. The lift shaft will be used to move the tanks to the B2 level. The mezzanine on B2 floor may not be constructed because the equipment that was originally here will now be in the vault area; however, a final decision has not been made yet.

\subsubsection{Anchoring Tanks to Floor B2}

The IO Assembly Group has suggested the use of imbedded threads to anchor the tanks to the B2 floor and at the same time share the use of available air pallets.

\subsection{THERMOHYDRAULIC CONDITIONS FOR THE DRAIN TANK DESIGN FOR NORMAL OPERATIONS}

The operational thermohydraulic parameters used for the design of the DTs depend on several modes of operation of the draining process. The two main modes of operation are normal and safety. The safety mode for the emergency DTs corresponds to the draining process during a LOCA event in the VV. The normal mode for normal DTs encompasses several stages such as draining of PHTSs, draining of invessel components, draining of surplus water inventory during water baking, and draining derived from the drying operations. This section analyzes each of these modes of operation to determine the normal operational thermohydraulic parameters.

\subsubsection{Normal Operation: Draining Only PHTSs}

Draining operations for the PHTSs assume draining for maintenance and inspection during which the water will be drained by gravity. Figure 10 illustrates this process. To start the draining process, it is assumed that the water temperature for each PHTS will be lowered and the pressure reduced to slightly above atmospheric conditions. ${ }^{10,11}$ 


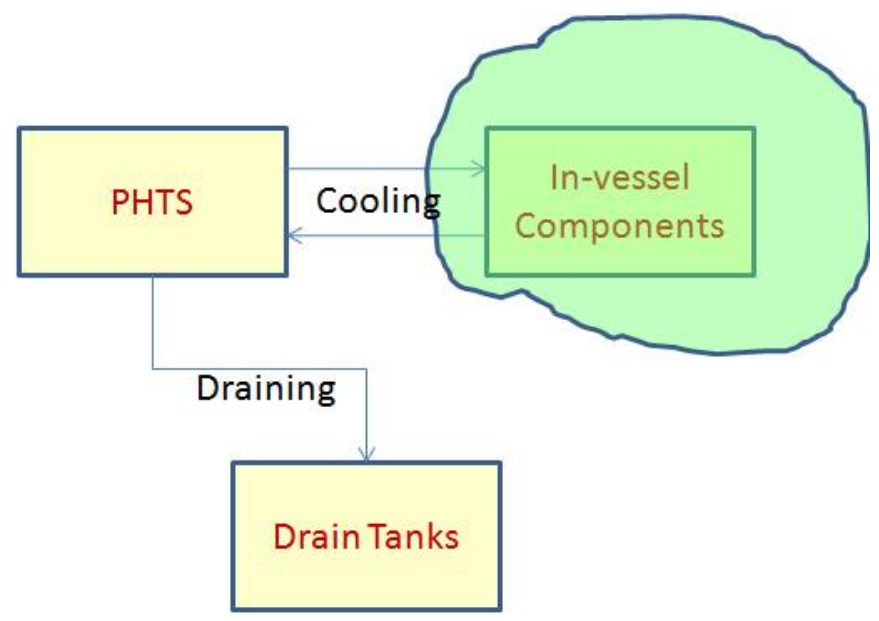

Fig. 10. Draining of the PHTS isolated from the invessel component.

Thermohydraulic parameters for the FW/BLK PHTS. The maintenance process is performed after a plasma operation has stopped. The inlet temperature of the coolant to the heat exchanger during plasma operations is $70^{\circ} \mathrm{C}$ (according to PCR 273) at a pressure less than $3.0 \mathrm{MPa}$.

Thermohydraulic parameters for the DIV PHTS. The maintenance process is performed after a plasma operation has stopped. The inlet temperature of the coolant to the heat exchanger during plasma operations is $70^{\circ} \mathrm{C}$ (according to PCR 273) at a pressure of less than $3.0 \mathrm{MPa}$.

Thermohydraulic parameters for the NBI PHTS. The maintenance process is performed after a plasma operation has stopped. The temperature during plasma operations is $90^{\circ} \mathrm{C}$ at a pressure of $2.0 \mathrm{MPa}$.

Thermohydraulic parameters for the VV PHTS. The maintenance process is performed after a plasma operation has stopped. The temperature during plasma operations is $100^{\circ} \mathrm{C}$ at a pressure of $0.8 \mathrm{MPa}$.

\subsubsection{Normal Operation: Draining of Surplus Water Inventory During Water Baking}

In preparation for water baking, there is water volume expansion during the heating process. This excess water goes to the Chemical and Volume Control System (CVCS) volume control tank, which has a water retention capacity of $10 \mathrm{~m}^{3}$ and cannot absorb all the excess water (this water retention capacity may change due to AREVA's design of the CVCS in accordance with PCR 273). As illustrated in Fig. 11, this excess needs to be drained into the corresponding DT.

The VV will be baked at $200^{\circ} \mathrm{C}$. Excess water due to volume expansion will be sent to the safety DTs. The VV PHTS will have a cooler for cooling this excess water. 


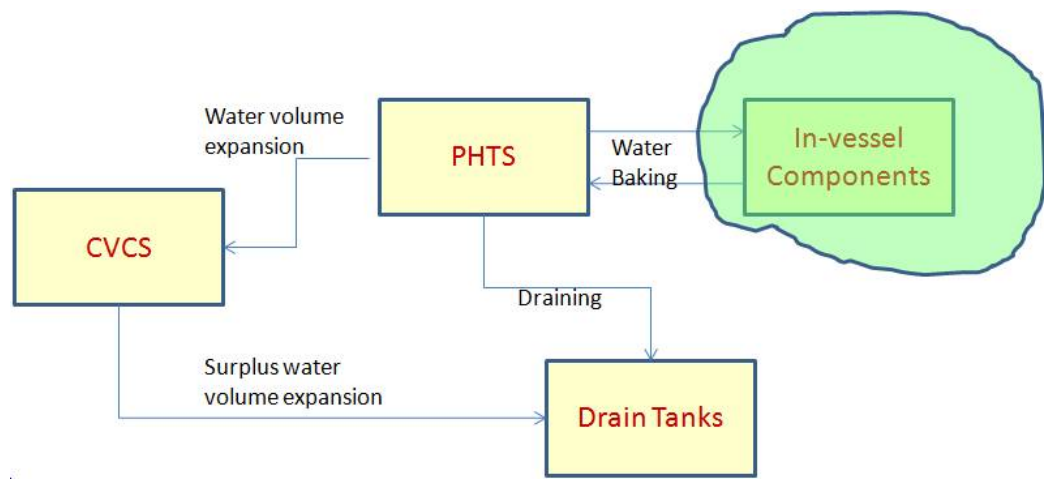

Fig. 11. Excess water from water baking being drained into the corresponding drain tank.

\subsubsection{Normal Draining Operation: From Draining and Drying Operations}

Design Description Document (DDD)-26 for the TCWS indicates that there are several operations to drain the in-vessel components and the PHTSs, starting with gravity drain, followed by forced drain, and a sequence of drying stages. All these stages involve draining water to the DTs. Although the draining and drying operations are described in DDD-26, they will be briefly described in the following paragraphs to be comprehensive and to provide AREVA a better understanding of the draining and drying processes to facilitate development of optimized procedures.

Gravity Draining. The first step in draining a system is to perform a gravity drain in the PHTS and in-vessel components as illustrated in Fig. 12. The PHTS must cool the in-vessel component to $100^{\circ} \mathrm{C}$ before the valves to the respective DTs open.

Forced Draining for the DIV Cassettes. Once the system is gravity-drained, fresh $\mathrm{N}_{2}$ gas is charged with

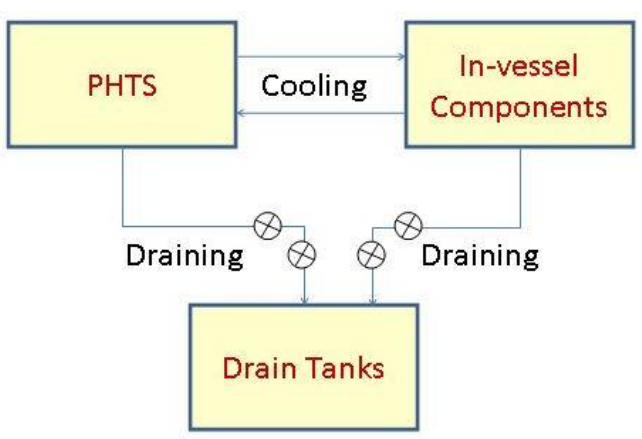

Fig. 12. Gravity drain from BLK and DIV PHTSs. a charging compressor as illustrated in Fig. 13.

The compressor starts to circulate working gas to the in-vessel components. Cooler condenser 1 cools the hot working gas after the compressor. Return gas is recycled by the drain and mist separators, cooler condenser 2, and the filter, as illustrated in Fig. 14. The ejected water from the in-vessel components is collected to the DIV sump tank through the drain line connected with the main hot leg pipeline near the coolant collector. The water separated and condensed is drained to the BLK/DIV DTs.

The main parameter for the forced draining is the kinematic pressure difference required to push away the remaining water in the water channels determined by the counter-current-flow-limitation (CCFL) criterion. The gas velocity that meets the CCFL criterion is inversely proportional to the square of the gas density. The gas density is proportional to pressure and is inversely proportional to the absolute temperature. Consequently, highly pressurized working gas with low temperature is preferable to reduce the CCFL velocity. The gas temperature is set around $40^{\circ} \mathrm{C}$, the same temperature as the water in the invessel components. The highest gas pressure at the discharge side of the compressor is $4 \mathrm{MPa}$. 


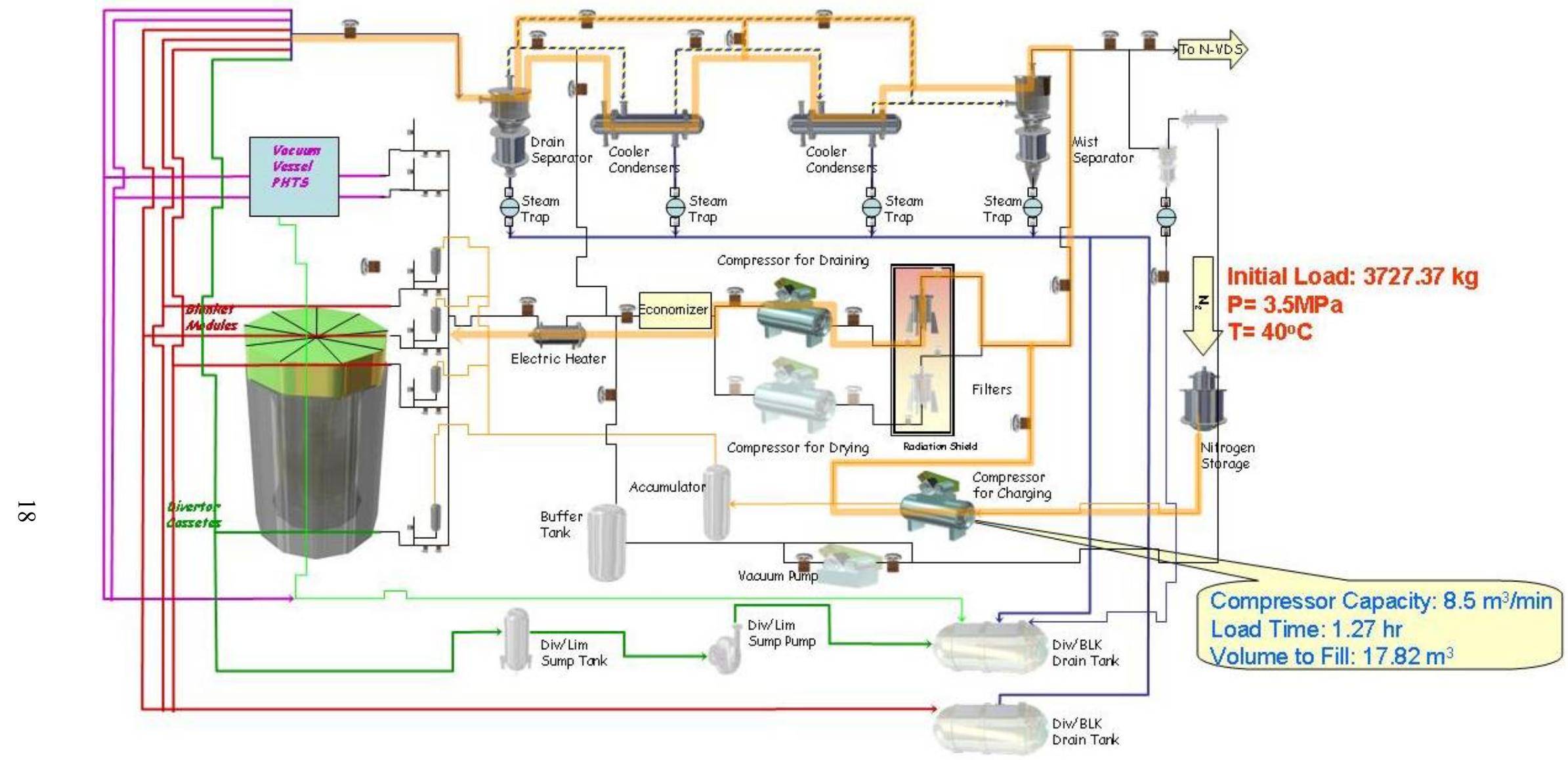




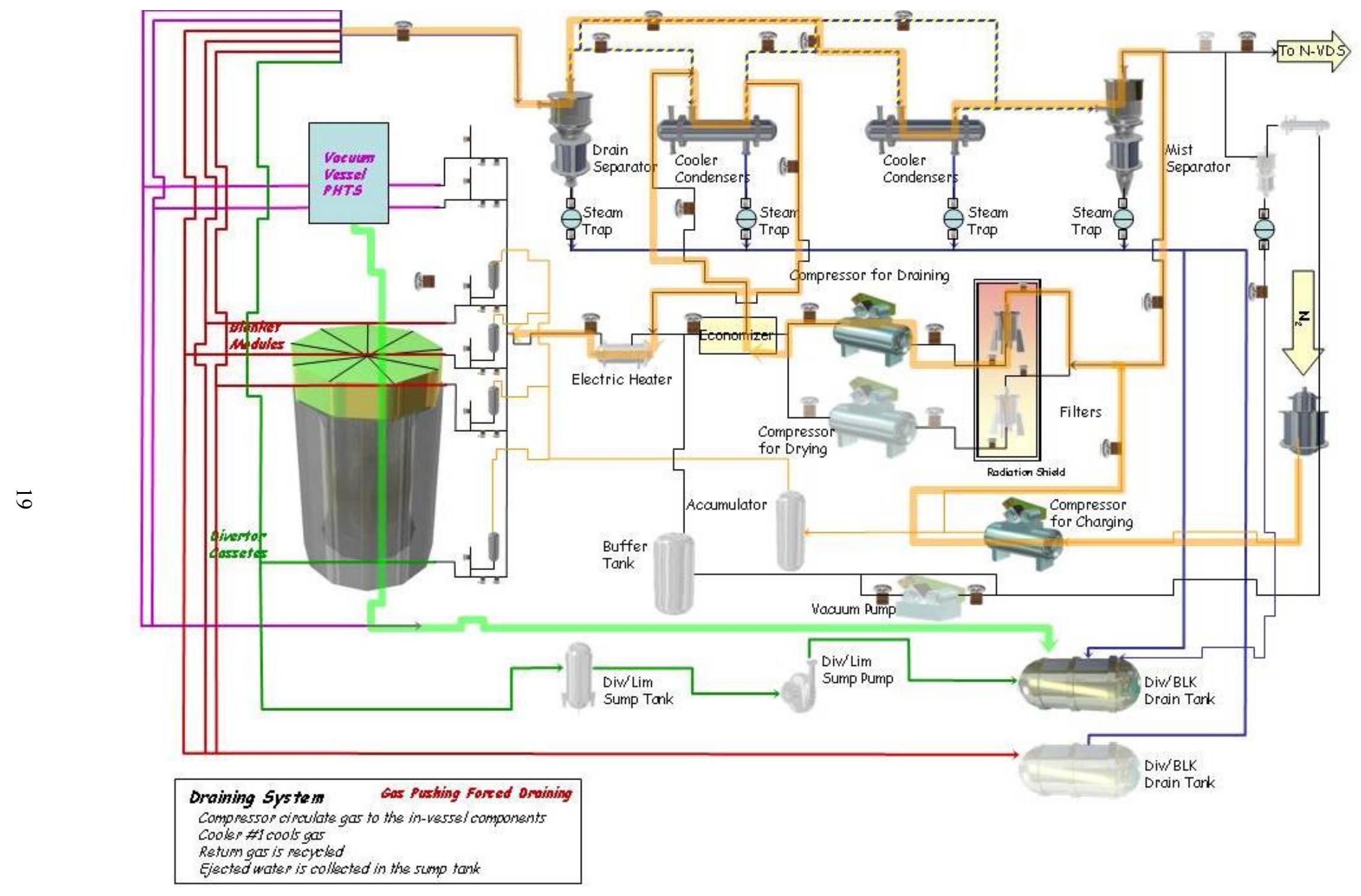

Fig. 14. Forced drain operation. 
Under these conditions, the water should drain at $40^{\circ} \mathrm{C}$, and the pressure should be reduced to atmospheric conditions after the pressure reduction valves.

Forced Draining for the Blankets. The forced draining of the blankets is similar to the DIV cassettes. The only difference is that three DIV cassettes are force drained at the same time and up to eight blanket modules are force drained at the same time. The temperature of the water is about $40^{\circ} \mathrm{C}$, and the pressure is about $3.8 \mathrm{MPa}$, which needs to be reduced to about $0.5 \mathrm{MPa}$. The water is collected at this temperature and the pressure reduced to atmospheric conditions after the pressure reduction valves.

Drying Operation: Heat Up Pressurization-Depressurization Mode. This is a drying operation phase that results in condensation of water that subsequently must be drained to the respective DT. This process is illustrated in Fig. 15. Working gas is circulated in the closed loop by the compressor and the two cooler condensers are bypassed. The working gas is heated by the compressor and the electrical heater. For pressure control during operations, additional charging of fresh gas from storage to the system and/or release of working gas from the system to the Normal Vent Detritiation System (N-VDS) buffer tank is performed. The maximum pressure during this process is about $2.3 \mathrm{MPa}$ and the temperature reaches $210^{\circ} \mathrm{C}$. The water remains liquid at these conditions and is not drained until the system is depressurized.

Once the conditions of temperature and pressure are met, the system is depressurized by transferring the excess working gas from the system to the N-VDS, maintaining working temperature of the system constant. Condensers 1 and 2 condense water mist, which is in the working gas. The transferring gas is extracted from the system by the N-VDS at a rate of $100 \mathrm{~m}^{3} / \mathrm{h}$. A gas blower at the entrance of the N-VDS provides the driving force to the gas transfer. Depressurization mode is illustrated in Fig. 16.

The condensed water is subcooled to $50^{\circ} \mathrm{C}$, and the pressure is reduced to meet atmospheric conditions.

\subsubsection{Analysis of Thermohydraulic Conditions for the Normal Operations of Drain Tanks}

Through the preliminary design process, AREVA will determine optimum thermohydraulic parameters and draining procedures using information in the conceptual design documented in DDD-26 as design input along with the results of other preliminary design studies.

\subsection{THERMOHYDRAULIC CONDITIONS FOR THE DRAIN TANK DESIGN FOR SAFETY OPERATIONS}

Table 3 shows an extract of Table 1.4.1 from System Requirements Document (SRD) 26 that shows the reference events that would use the safety DTs. The safety DTs shall be

- designed to accept the contaminated water from the VV and from the VVPSS in case of in-vessel pipe breaks, as required;

- capable of discharging the contaminated water to Radwaste Building (Plant Breakdown Structure [PBS] 66) for processing; and

- designed to allow cleaning and decontamination before the plant restarts. 


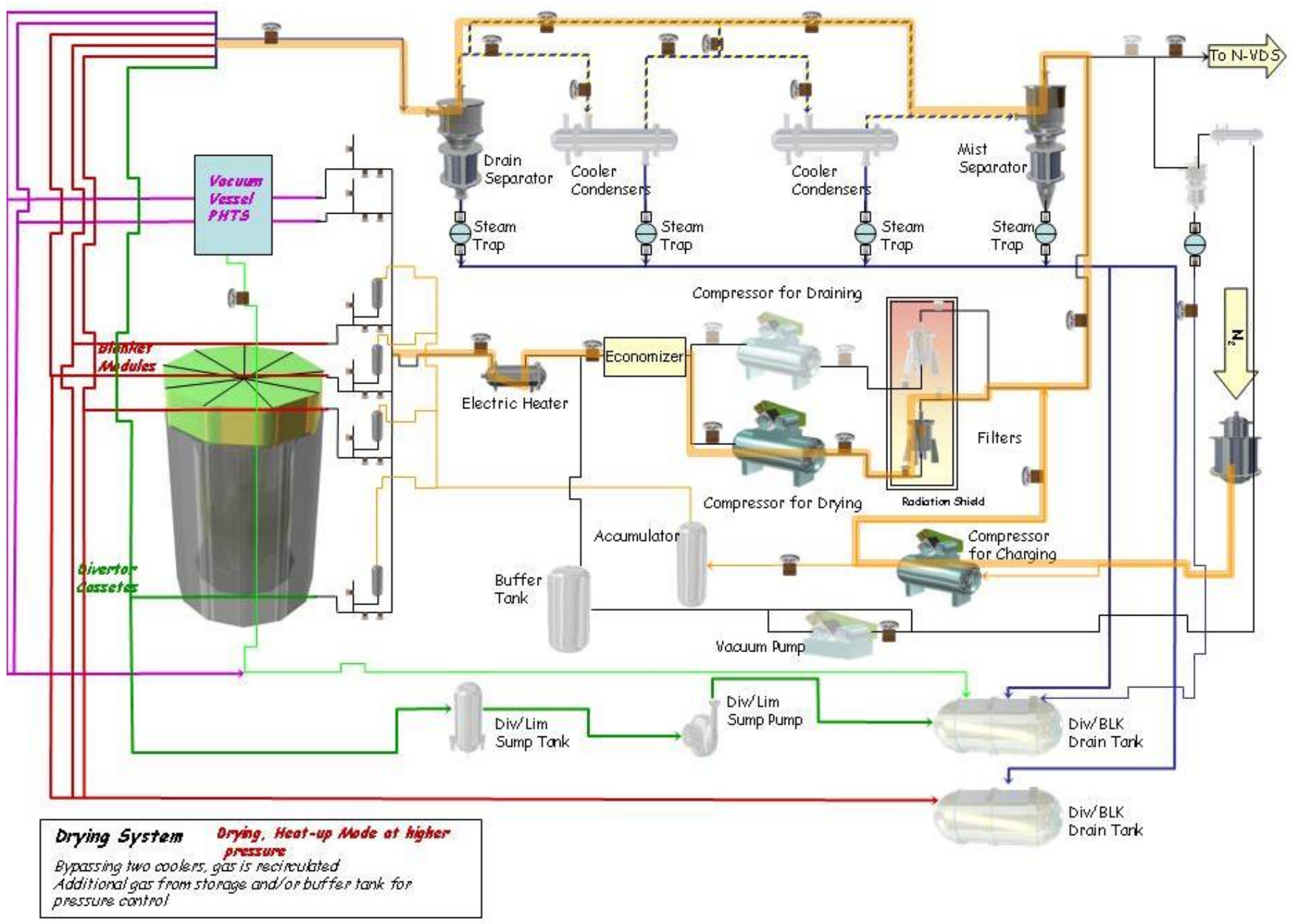

Fig. 15. Heat-up mode at higher pressure. 


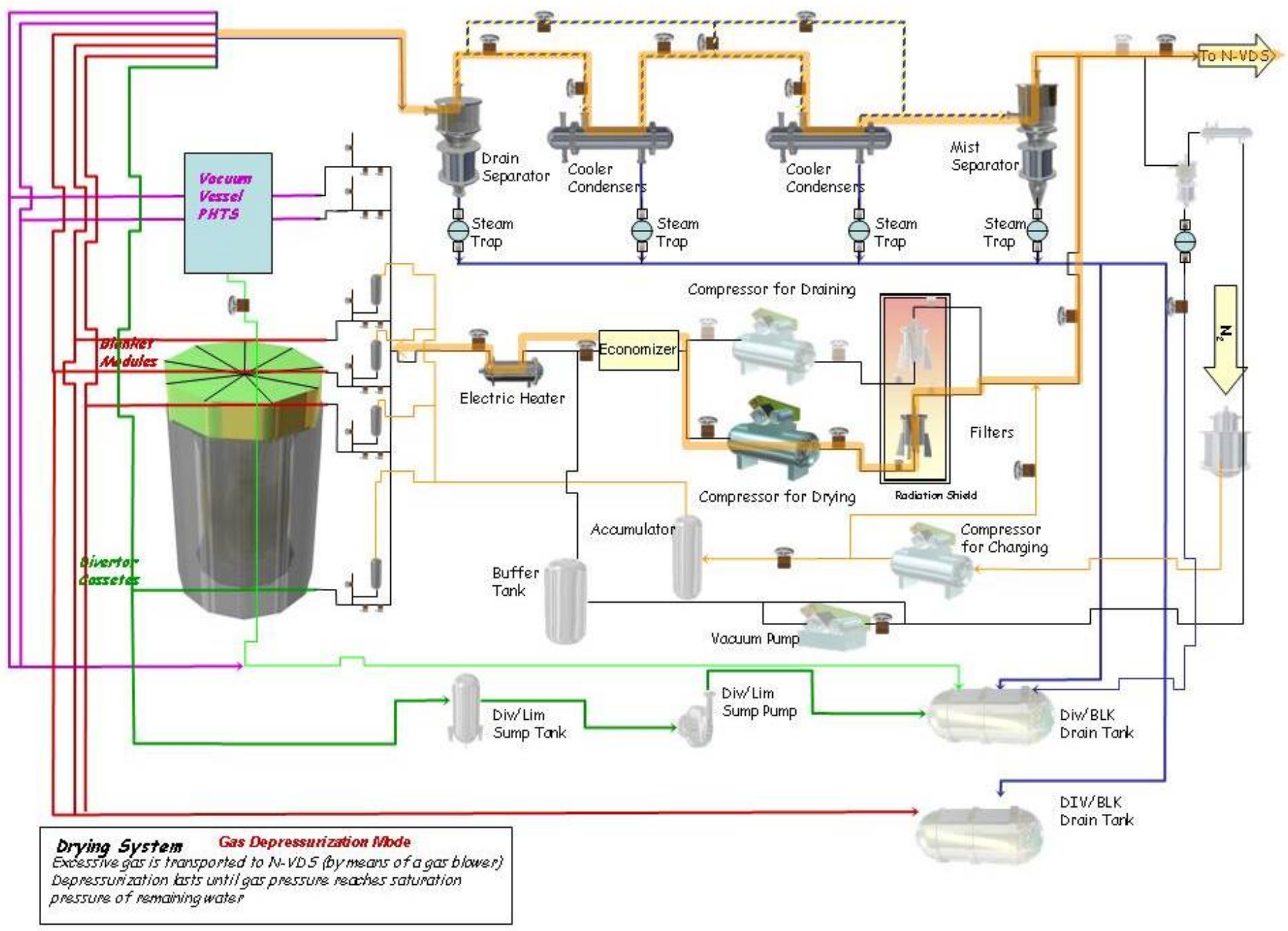

Fig. 16. Depressurization mode. 
Table 3. Extract of Table 1.4.1 from System Requirements Document 26

\begin{tabular}{|c|c|c|c|}
\hline Event title & Category & Global design requirements & $\begin{array}{l}\text { TCWS design } \\
\text { requirements }\end{array}$ \\
\hline $\begin{array}{l}\text { Multiple FW/ } \\
\text { BLK cooling } \\
\text { water pipe } \\
\text { break }\end{array}$ & Accident & $\begin{array}{l}\text { VV safety assessment pressure limit } 0.2 \mathrm{MPa} \text {; VV leak rate; } \\
\text { VVPSS bleed-line set point } 94 \mathrm{kPa} \text {; VVPSS rupture disk } \\
\text { set-point } 0.15 \mathrm{MPa} \text {; VV PHTS low flow safety mode }\end{array}$ & $\begin{array}{l}\text { - Decay heat cooling } \\
\text { capability of VV } \\
\text { PHTS } \\
\text { - Safety drain lines } \\
\text { - Safety DTs }\end{array}$ \\
\hline $\begin{array}{l}\text { In-vessel FW } \\
\text { pipe break }\end{array}$ & Incident & $\begin{array}{l}\text { VV safety assessment pressure limit } 0.2 \mathrm{MPa} \text {; VVPSS } \\
\text { bleed-line set point } 94 \mathrm{kPa} \text {; VVPSS drain valves open in } \\
1 \text { hour after the onset of the incident; Suppression Tank } \\
\text { Venting System capability; VV PHTS low flow safety } \\
\text { mode; N-VDS serves the port cells and TCWS vault }\end{array}$ & $\begin{array}{l}\text { - Decay heat cooling } \\
\text { capability of VV } \\
\text { PHTS } \\
\text { - Safety DTs }\end{array}$ \\
\hline
\end{tabular}

Calculations described in Sect. 2.2 indicate that the maximum pressure in the DTs is $80 \mathrm{kPa}(0.080 \mathrm{MPa})$ and the maximum temperature is $94^{\circ} \mathrm{C}$ after a LOCA event and after the operators have decided to open the drain valves. The initial conditions of the safety DTs are $4 \mathrm{kPa}$ and $30^{\circ} \mathrm{C}$.

Results from the IO Safety Group indicated that the design temperature for the safety DTs is $94^{\circ} \mathrm{C}$ plus an uncertainty factor, determined according to sound engineering practices, to accommodate the uncertainties of the calculations. The design pressure was indicated as $0.9 \mathrm{MPa}$, again incorporating an uncertainty factor to account for the uncertainties of the calculations, as well as the DDD-26 indicated $1 \mathrm{MPa}$ design pressure. Vacuum conditions on the DT correspond to a $0.01 \mathrm{MPa}$ according to DDD-26. The $1 \mathrm{MPa}$ design pressure for the DTs is based on the possibility that the nitrogen valve that feeds the normal DTs breaks and suddenly the tank will be at the nitrogen feed pressure $(0.9 \mathrm{MPa})$.

\subsection{DRAIN TANK INTERFACES}

The DTs interface with several systems (PBSs) within the Tokamak complex. There are external PBSs where the DTs send water; cooling water client PBSs that send water to the DTs; TCWS internal systems that send and receive water to the DTs; external systems that provide gas and demineralized water services to the DTs; and general external services such as electric, air, and sampling. Figure 17 illustrates the DT interfaces, and Appendix B shows some CATIA pictures of the DTs with a few interfaces.

\subsubsection{Interfaces to the Drain Tanks}

Normal Operations (Water to DTs). The interfaces that send water to the normal DTs are as follows.

- FW/BLK PHTS

- DIV PHTS

- NBI PHTS

- VV PHTS

- Drying system

- FW/BLK in-vessel components

- VV components

- DIV in-vessel components

- NBI internal components

- Pressure relief tanks 


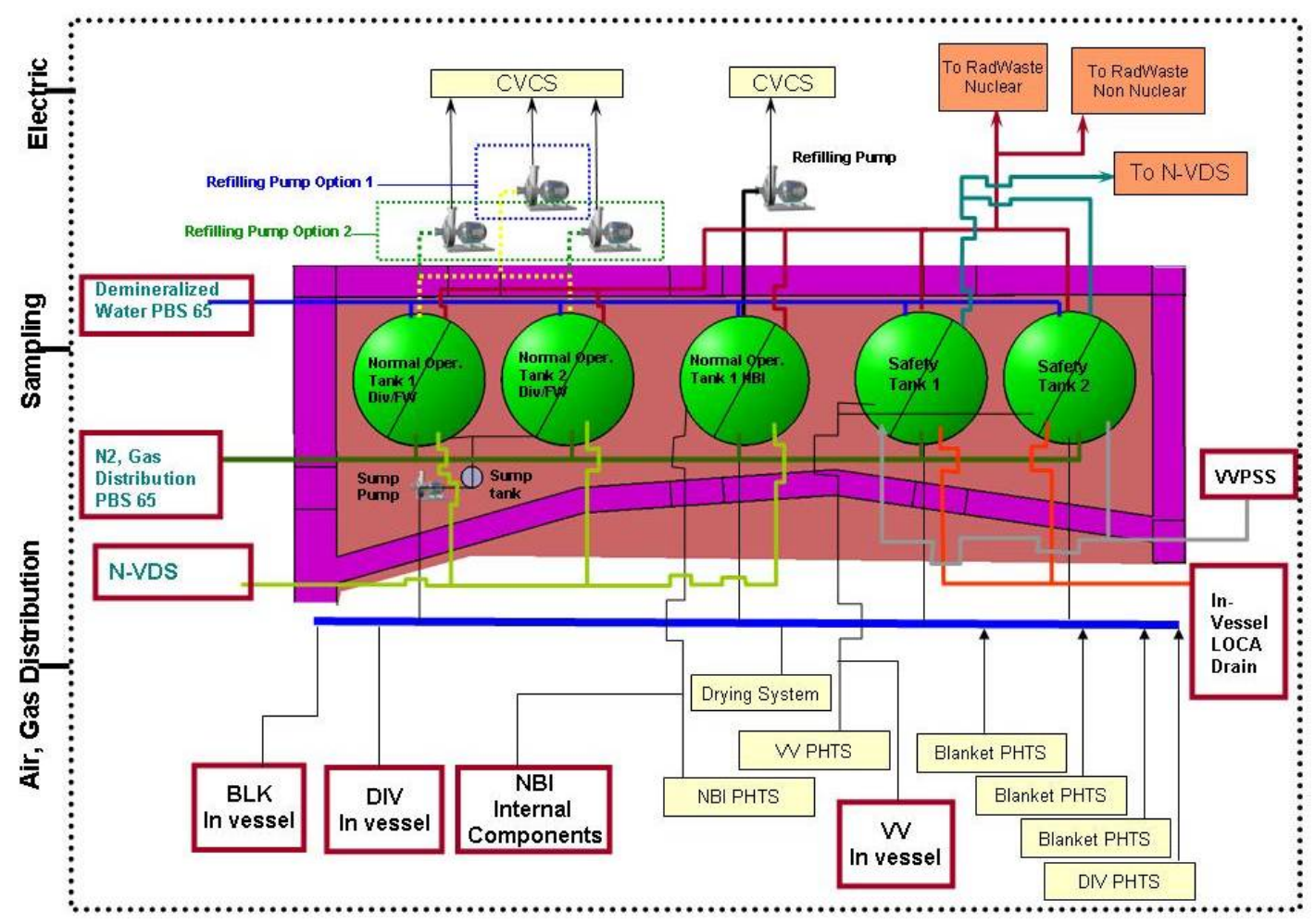

Fig. 17. Graphical representation of the drain tank interfaces.

Safety Operations (Water to DTs). The interfaces that send water to the safety DTs are as follows.

- VV in-vessel components (LOCA emergency drain)

- VVPSS

- VV PHTS

\subsubsection{Interfaces From the Drain Tanks}

Normal Operations (Water from DTs). The interfaces that receive water from the normal operation DTs are as follows.

- CVCS (water from the BLK/DIV DTs through a refilling pump)

- CVCS (water from the NBI DT through a refilling pump)

- VV PHTS (water from safety DTs through a refilling pump)

Safety Operations (Water from DTs). The following interface receives radioactive liquid from the DTs: Radwaste (radioactive liquid waste from normal and safety tanks) (PBS 66).

Disposal Operations. The following inteface receives nonradioactive liquid from the DTs: Disposal (nonradioactive liquid waste from the normal and safety DTs, bypassing Radwaste).

\subsubsection{General Interfaces}

Several of the DT interfaces allow different purposes, as described below. 
- Demineralized water. This water will come from the Gas and Liquid Distribution System to supply the needs for filling, refilling, and cleaning. The demineralized water connection point is to be provided at the safety DTs to facilitate decontamination of the tanks

- Nitrogen distribution system. Nitrogen is used to keep a gas blanket in the DTs.

- N-VDS. Venting from the tanks is performed using the N-VDS system. Vacuum for safety DTs is performed using the N-VDS system.

- Electric group. The refilling pumps and sump tank pump interface with the electric group. There are instruments and controls that also interface with the electric group.

- Air distribution system. Air is used for instruments and controls.

Appendix B shows some of the interfaces with the DTs.

A general interface and operational feature that the DTs need to have to operate appropriately is vortexing prevention. During refill, vortexing could cause un-dissolved nitrogen ingestion into the CVCS pumps. A tank bladder might also be something to consider (provides barrier between blanket gas and fluid). A nitrogen blanket may be unnecessary if a bladder is used; however, the use of a plastic bladder needs to be studied.

The tanks need to have a device to promote vacuum breaking to avoid tank collapse for a sudden vacuum on the tanks that may result from the tank being emptied.

Interfaces with other systems are formalized in interface control documents (ICDs) and interface sheets (ISs). The DT interfaces are included in the draft ICDs referenced in Table 4. This is a draft table that includes preliminary information about the DT interfaces. The ICDs referenced in this table represent a system level description of the interfaces, along with important interfacing agreements and agreed upon schedules between the interfacing systems. As evidenced in Table 4, these ICDs are mostly approved but will be revised and updated at a minimum at the end of the Preliminary and Final Design Phases of the project to account for any potential design changes. The ISs include the technical details associated with the interfaces. The initial drafts of these documents are currently in progress but by and large have not yet been completed. Once completed, these approved documents will be needed for preliminary design. As with the ICDs, the ISs will also be revised and updated throughout the Preliminary and Final Design Phases of the project. 
Table 4. Tokamak Cooling Water System drain tank interfaces

\begin{tabular}{|c|c|c|c|c|c|c|c|c|c|}
\hline $\begin{array}{c}\text { PBS } \\
\text { system } \\
\text { number }\end{array}$ & $\begin{array}{c}\text { Drain } \\
\text { interface } \\
\text { (Yes/No) }\end{array}$ & $\begin{array}{l}\text { Interface } \\
\text { type }\end{array}$ & $\begin{array}{l}\text { Interface } \\
\text { location }\end{array}$ & $\begin{array}{c}\text { Interface } \\
\text { TCWS equipment ID }\end{array}$ & $\begin{array}{c}\text { ICD } \\
\text { document }\end{array}$ & $\begin{array}{l}\text { ICD } \\
\text { status }\end{array}$ & $\begin{array}{c}\text { IS } \\
\text { document }\end{array}$ & $\begin{array}{c}\text { IS } \\
\text { status }\end{array}$ & Notes \\
\hline $15 \mathrm{VV}$ & YES & Client & $\begin{array}{l}\text { To be } \\
\text { determined } \\
\text { (TBD) }\end{array}$ & 26DRFB-TA-0003 & ICD $15-26$ & Approved & IS $15-26$ & Approved & Safety tank \\
\hline $15 \mathrm{VV}$ & YES & Client & TBD & 26DRFB-TA-0001 & ICD $15-26$ & Approved & IS $15-26$ & Approved & Normal tank \\
\hline 16 & YES & Client & TBD & 26DRFB-TA-0004 & ICD 16-26 & Approved & TBD & Not begun & Safety tank \\
\hline 16 & YES & Client & TBD & 26DRFB-TA-0002 & ICD $16-26$ & Approved & TBD & Not begun & Normal tank \\
\hline 17 & YES & Client & $\begin{array}{l}\text { 11-B2M } \\
\text { Lower Pipe } \\
\text { Chase Level } \\
\text { B2M }\end{array}$ & 26DRFB-TA-0003 & ICD $17-26$ & Approved & TBD & Not begun & Safety tank \\
\hline 17 & YES & Client & $\begin{array}{l}11-B 2 M \\
\text { Lower Pipe } \\
\text { Chase Level } \\
\text { B2M }\end{array}$ & 26DRFB-TA-0002 & ICD $17-26$ & Approved & TBD & Not begun & Normal tank \\
\hline $24 \mathrm{VP}$ & YES & Client & TBD & 26DRFB-TA-0004 & ICD 24VP-26 & Approved & TBD & Not begun & Safety tank \\
\hline $26 \mathrm{PH}$ & YES & Client & $\begin{array}{l}\text { 11-L4 Crane } \\
\text { Hall and } \\
\text { TCWS Vault } \\
\text { L4 }\end{array}$ & 26DRFB-TA-0001 & N/A & Approved & TBD & Not begun & Normal tank \\
\hline $26 \mathrm{PH}$ & YES & Client & $\begin{array}{l}\text { 11-L4 Crane } \\
\text { Hall and } \\
\text { TCWS Vault } \\
\text { L4 }\end{array}$ & 26DRFB-TA-0002 & N/A & Approved & TBD & Not begun & Normal tank \\
\hline $26 \mathrm{PH}$ & YES & Client & $\begin{array}{l}\text { 11-L4 Crane } \\
\text { Hall and } \\
\text { TCWS Vault } \\
\text { L4 }\end{array}$ & 26DRNB-TA-0001 & N/A & Approved & TBD & Not begun & Normal tank \\
\hline $26 \mathrm{CV}$ & YES & Client & TBD & 26DRFB-TA-0001 & N/A & Approved & TBD & Not begun & Normal tank \\
\hline $26 \mathrm{CV}$ & YES & Client & TBD & 26DRFB-TA-0002 & N/A & Approved & TBD & Not begun & Normal tank \\
\hline
\end{tabular}




\begin{tabular}{|c|c|c|c|c|c|c|c|c|c|}
\hline $\begin{array}{c}\text { PBS } \\
\text { system } \\
\text { number }\end{array}$ & $\begin{array}{c}\text { Drain } \\
\text { interface } \\
\text { (Yes } / \text { No) }\end{array}$ & $\begin{array}{c}\text { Interface } \\
\text { type }\end{array}$ & $\begin{array}{l}\text { Interface } \\
\text { location }\end{array}$ & $\begin{array}{c}\text { Interface } \\
\text { TCWS equipment ID }\end{array}$ & $\begin{array}{c}\text { ICD } \\
\text { document }\end{array}$ & $\begin{array}{l}\text { ICD } \\
\text { status }\end{array}$ & $\begin{array}{c}\text { IS } \\
\text { document }\end{array}$ & $\begin{array}{l}\text { IS } \\
\text { status }\end{array}$ & Notes \\
\hline $26 \mathrm{CV}$ & YES & Client & TBD & 26DRNB-TA-0001 & N/A & Approved & TBD & Not begun & Normal tank \\
\hline $26 \mathrm{DY}$ & YES & Client & Annex Vault & 26DRFB-TA-0001 & N/A & Approved & TBD & Not begun & Normal tank \\
\hline $26 \mathrm{DY}$ & YES & Client & Annex Vault & 26DRFB-TA-0002 & N/A & Approved & TBD & Not begun & Normal tank \\
\hline $26 \mathrm{DY}$ & YES & Client & Annex Vault & 26DRNB-TA-0001 & $\mathrm{N} / \mathrm{A}$ & Approved & TBD & Not begun & Normal tank \\
\hline 31 & YES & Server & Annex Vault & 26DRFB-TA-0001 & ICD 26-31 & Approved & TBD & Not begun & Safety tank \\
\hline 32 & YES & Server & Annex Vault & 26DRFB-TA-0003 & ICD 26-32 & Approved & TBD & Not begun & Safety tank \\
\hline 32 & YES & Server & Annex Vault & 26DRFB-TA-0004 & ICD 26-32 & Approved & TBD & Not begun & Safety tank \\
\hline 32 & YES & Server & Annex Vault & 26DRFB-TA-0001 & ICD 26-32 & Approved & TBD & Not begun & Normal tank \\
\hline 32 & YES & Server & Annex Vault & 26DRFB-TA-0002 & ICD 26-32 & Approved & TBD & Not begun & Normal tank \\
\hline 32 & YES & Server & Annex Vault & 26DRNB-TA-0001 & ICD 26-32 & Approved & TBD & Not begun & Normal tank \\
\hline 43 & YES & Server & $\begin{array}{l}11-\mathrm{B} 2 \\
\text { Basement } \\
\text { Level B2 }\end{array}$ & $\begin{array}{l}\text { Multiple pumps/ } \\
\text { motors }\end{array}$ & ICD 26-43 & Approved & TBD & Not begun & TBD \\
\hline 53 & YES & Client & TBD & 26DRFB-TA-0001 & ICD 53-26 & Approved & TBD & Not begun & Normal tank \\
\hline 53 & YES & Client & TBD & 26DRFB-TA-0002 & ICD 53-26 & Approved & IS 26-53-001 & Approved & Normal tank \\
\hline 53 & YES & Client & TBD & 26DRNB-TA-0001 & ICD 53-26 & Approved & IS $26-53-003$ & Approved & Normal tank \\
\hline $65-\mathrm{CA}$ & YES & Server & Annex Vault & 26DRFB-TA-0003 & ICD 26-65CA & Approved & $\begin{array}{l}\text { IS-65.CA-26. } \\
\text { TC-001;-007 }\end{array}$ & Signed & Safety tank \\
\hline $65-\mathrm{CA}$ & YES & Server & Annex Vault & 26DRFB-TA-0004 & ICD $26-65 C A$ & Approved & $\begin{array}{l}\text { IS-65.CA-26. } \\
\text { TC-001;-007 }\end{array}$ & Signed & Safety tank \\
\hline $65-\mathrm{CA}$ & YES & Server & Annex Vault & 26DRFB-TA-0001 & ICD 26-65CA & Approved & $\begin{array}{l}\text { IS-65.CA-26. } \\
\text { TC-001;-007 }\end{array}$ & Signed & Normal tank \\
\hline $65-\mathrm{CA}$ & YES & Server & Annex Vault & 26DRFB-TA-0002 & ICD 26-65CA & Approved & $\begin{array}{l}\text { IS-65.CA-26. } \\
\text { TC-001;-007 }\end{array}$ & Signed & Normal tank \\
\hline $65-\mathrm{CA}$ & YES & Server & Annex Vault & 26DRNB-TA-0001 & ICD $26-65 C A$ & Approved & $\begin{array}{l}\text { IS-65.CA-26. } \\
\text { TC-001;-007 }\end{array}$ & Signed & Normal tank \\
\hline 65-DW & YES & Server & Annex Vault & 26DRFB-TA-0003 & ICD 26-65DW & Approved & $\begin{array}{l}\text { IS-65.DW-26. } \\
\text { TC-001;-002 }\end{array}$ & Signed & Safety tank \\
\hline
\end{tabular}




\begin{tabular}{|c|c|c|c|c|c|c|c|c|c|}
\hline $\begin{array}{c}\text { PBS } \\
\text { system } \\
\text { number }\end{array}$ & $\begin{array}{c}\text { Drain } \\
\text { interface } \\
\text { (Yes/No) }\end{array}$ & $\begin{array}{l}\text { Interface } \\
\text { type }\end{array}$ & $\begin{array}{l}\text { Interface } \\
\text { location }\end{array}$ & $\begin{array}{c}\text { Interface } \\
\text { TCWS equipment ID }\end{array}$ & $\begin{array}{c}\text { ICD } \\
\text { document }\end{array}$ & $\begin{array}{l}\text { ICD } \\
\text { status }\end{array}$ & $\begin{array}{c}\text { IS } \\
\text { document }\end{array}$ & $\begin{array}{l}\text { IS } \\
\text { status }\end{array}$ & Notes \\
\hline $65-\mathrm{DW}$ & YES & Server & Annex Vault & 26DRFB-TA-0004 & ICD 26-65DW & Approved & $\begin{array}{l}\text { IS-65.DW-26. } \\
\text { TC-001;-002 }\end{array}$ & Signed & Safety tank \\
\hline 65-DW & YES & Server & Annex Vault & 26DRFB-TA-0001 & ICD 26-65DW & Approved & $\begin{array}{l}\text { IS-65.DW-26. } \\
\text { TC-001;-002 }\end{array}$ & Signed & Normal tank \\
\hline 65-DW & YES & Server & Annex Vault & 26DRFB-TA-0002 & ICD 26-65DW & Approved & $\begin{array}{l}\text { IS-65.DW-26. } \\
\text { TC-001;-002 }\end{array}$ & Signed & Normal tank \\
\hline 65-DW & YES & Server & Annex Vault & 26DRNB-TA-0001 & ICD 26-65DW & Approved & $\begin{array}{l}\text { IS-65.DW-26. } \\
\text { TC-001;-002 }\end{array}$ & Signed & Normal tank \\
\hline $65-\mathrm{NG}$ & YES & Server & Annex Vault & 26DRFB-TA-0003 & ICD 26-65NG & Approved & $\begin{array}{l}\text { IS-65.NG-26. } \\
\text { TC-001;-002 }\end{array}$ & Signed & Safety tank \\
\hline $65-\mathrm{NG}$ & YES & Server & Annex Vault & 26DRFB-TA-0004 & ICD 26-65NG & Approved & $\begin{array}{l}\text { IS-65.NG-26. } \\
\text { TC-001;-002 }\end{array}$ & Signed & Safety tank \\
\hline $65-\mathrm{NG}$ & YES & Server & Annex Vault & 26DRFB-TA-0001 & ICD $26-65 \mathrm{NG}$ & Approved & $\begin{array}{l}\text { IS-65.NG-26. } \\
\text { TC-001;-002 }\end{array}$ & Signed & Normal tank \\
\hline $65-\mathrm{NG}$ & YES & Server & Annex Vault & 26DRFB-TA-0002 & ICD $26-65 \mathrm{NG}$ & Approved & $\begin{array}{l}\text { IS-65.NG-26. } \\
\text { TC-001;-002 }\end{array}$ & Signed & Normal tank \\
\hline $65-\mathrm{NG}$ & YES & Server & Annex Vault & 26DRNB-TA-0001 & ICD 26-65NG & Approved & $\begin{array}{l}\text { IS-65.NG-26. } \\
\text { TC-001;-002 }\end{array}$ & Signed & Normal tank \\
\hline 66 & YES & Server & Annex Vault & 26DRFB-TA-0003 & ICD 26-66 & Approved & TBD & Not begun & Safety tank \\
\hline 66 & YES & Server & Annex Vault & 26DRFB-TA-0004 & ICD 26-66 & Approved & TBD & Not begun & Safety tank \\
\hline
\end{tabular}




\subsection{DRAIN TANK FLOODING CONDITIONS}

Safety requirements for the DT area indicate that the tanks need to be enclosed in an area that allows flooding from the tanks that includes $50 \%$ of the total capacity of the tanks. ${ }^{12}$ Based on this information, the height of water under flooding conditions should be calculated by AREVA, and the refilling pumps and the sump tank pump should be located at a height above this level. Figure 18 indicates the use of space in the tank area, including the volume that can be used at the mezzanine.

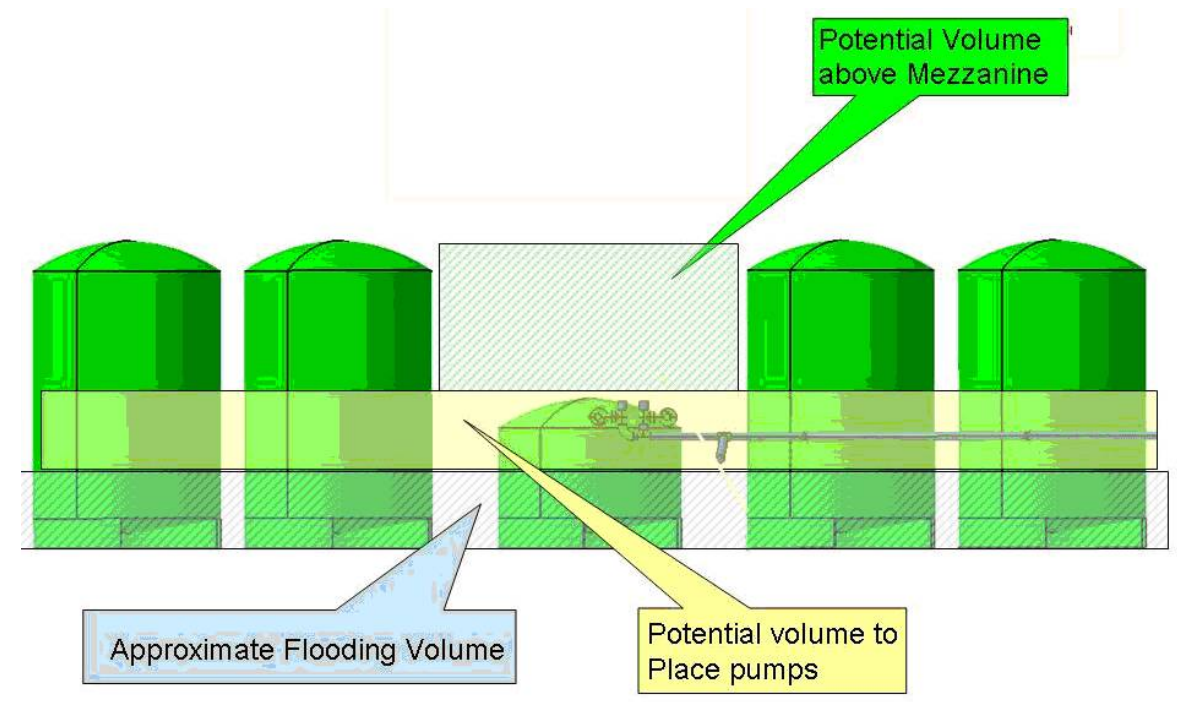

Fig. 18. Drain tank flooding conditions.

\subsection{CLEANING PROVISIONS}

The safety DTs can receive radioactively contaminated water from the VV chamber. Once this liquid waste is sent to Radwaste Building (PBS 66), the empty tanks need to be washed with appropriate liquid, and this liquid waste must also be sent to Radwaste Building. The DTs shall include features that will facilitate cleaning to allow the restart of the plant within 1 year of any such occurrence (Appendix A).

\subsection{DRAIN TANK CLASSIFICATION}

In accordance with the French order dated December 12, 2005, concerning nuclear pressure equipment (ESPN or Nuclear Pressure Equipment Order 2005), the operator of a basic nuclear facility must compile a list of nuclear pressure equipment used in the facility.

This list and related justifications have been made available to the French nuclear regulatory body (currently L'Autorité de sûreté nucléaire [ASN]) for Preliminary Safety Report submission. ${ }^{13}$

The 2004 design considers the storage tanks segmented for each PHTS to avoid mixing cooling fluids with different contamination levels or chemistry requirements. Consequently, the 2004 tank design includes two tanks for the VV; two tanks for the FW/BLK, one of which has a safety function; two tanks for the DIV, one of which has a safety function; and two tanks for the NBI, one of which has a safety function. The safety function is related to a LOCA in the respective in-vessel component (BLK, DIV). 
Some current design changes indicate that both BLK and DIV will use copper; consequently, there is no need to have exclusive tanks to receive the respective waters. The tanks can be interconnected to receive water from both systems.

Clarification of the VV operations indicates that the VVs will need to be drained only three times over the lifetime of the system. The first time corresponds to the initial joint field testing when the spent water can be directly disposed into the sewage after the testing is done. The second time is before the reactor enters the radioactive phase of operations when the field joints need to be tested again, and this water can also be disposed to the sewage system. The third time is after the lifetime of the reactor has ended, and this waste water is radioactive and thus needs to be disposed into the radioactive waste water system. The conclusion of this clarification indicates that the VV DTs are not needed for normal VV operations. If a LOCA scenario occurs, then no matter the origin of the water, it will constitute waste water that can be collected in any of the safety tanks not requiring segregation. This is a good opportunity to homogenize the tank design and decrease their number.

The current drain tank configuration is as follows:

- two identical tanks of $270 \mathrm{~m}^{3}$ for normal operations,

- two identical tanks of $250 \mathrm{~m}^{3}$ for safety activities,

- one tank of $120 \mathrm{~m} 3$ for the NBI, and

- no drain tank for VV. VV drainage water can be collected by normal operation tank.

The four original sump tanks (from version 2004) have been reduced to one sump tank that can collect liquid from normal operations of the DIV and FW/BLK.

\subsubsection{Normal Drain Tanks (3)}

\section{Design Parameters}

Size: diameter $6.25 \mathrm{~m}$ by $10.25 \mathrm{~m}$

Volume: $270 \mathrm{~m}^{3}$

Design pressure: 10 bar

Design temperature: $<100^{\circ} \mathrm{C}$

Coolant radioactivity concentration: $9.45 \mathrm{GBq} / \mathrm{m}^{3}$ (FW/BLK loop, without N16\&N17 contribution; refer to ITER_D_26GLXV v2.4)

\section{ESPN and ESP Classification}

The total radioactivity of the DT will be $2,281.5 \mathrm{GBq}(9.45 \times 270=2,281.5)$. This value is above $370 \mathrm{GBq}$. That means the tank will fall into the N2 category as defined in ESPN.

For the Pressure Hazard classification, the DT is classified as Category I. Figure 19 shows details. 


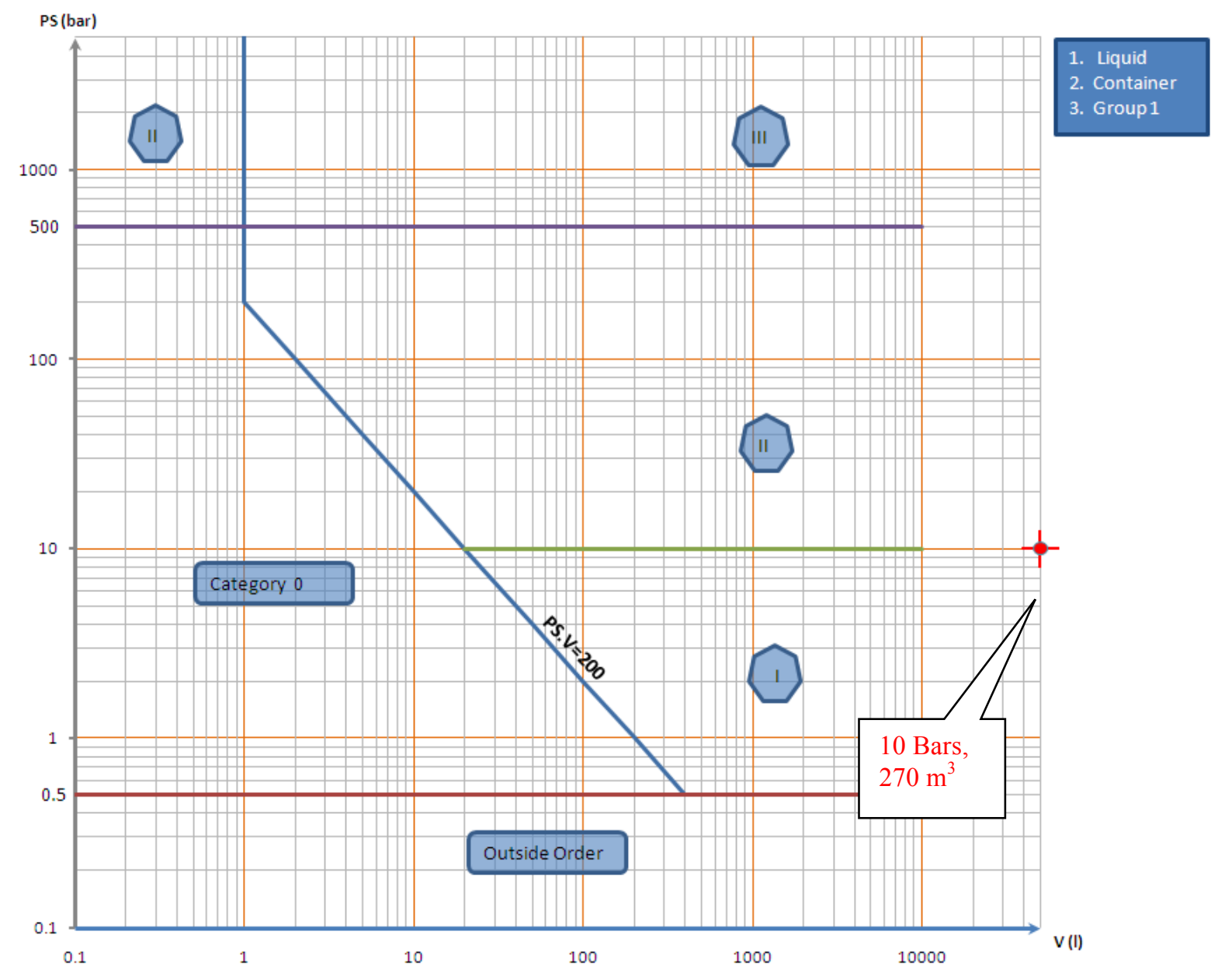

Fig. 19. Classification for normal drain tanks.

To conclude, the normal DT is classified as Nuclear Level N2, Pressure Category I.

\subsubsection{Safety Drain Tanks (Two Tanks)}

\section{Design Parameters}

Size: Diameter $6.25 \mathrm{~m}$ by $10.25 \mathrm{~m}$ (TBD)

Volume: $250 \mathrm{~m}^{3}$

Design pressure: 10 bar

Design temperature: $<100^{\circ} \mathrm{C}$

Coolant radioactivity concentration: $>9.45 \mathrm{GBq} / \mathrm{m}^{3}$

\section{ESPN and ESP Classification}

The total radioactivity of the safety DT will be more than $2,112.5 \mathrm{GBq}(9.45 \times 250=2,281.5)$. This value is above $370 \mathrm{GBq}$. That means the tank will fall into the N2 category as defined in ESPN. 
For the Pressure Hazard classification, the safety DT is classified as Category I. Figure 20 shows details.

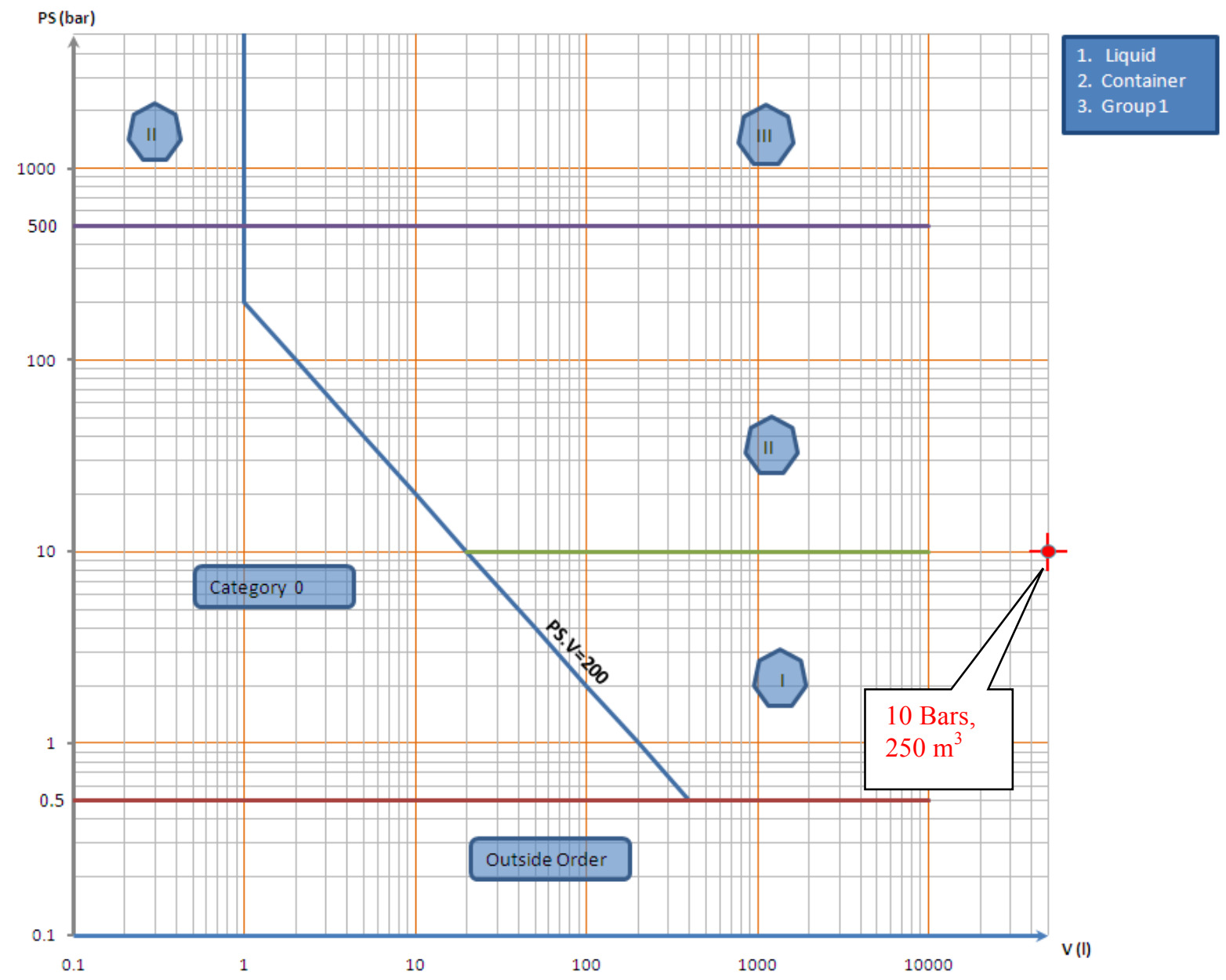

Fig. 20. Classification for the safety drain tanks.

To conclude, the safety DTs are classified as Nuclear Level N2, Pressure Category I.

\subsubsection{NBI Drain Tanks (One Tank)}

\section{Design Parameters}

Size: Diameter $6.1 \mathrm{~m}$ by $5 \mathrm{~m}(\mathrm{TBD})$

Volume: $120 \mathrm{~m}^{3}$

Design pressure: 10 bar

Design temperature: $<100^{\circ} \mathrm{C}$

Coolant radioactivity concentration: $1.86 \mathrm{GBq} / \mathrm{m}^{3}$ (NBI loop, without N16\&N17 contribution; refer to ITER_D_26GLXV v2.4) 


\section{ESPN and ESP Classification}

The total radioactivity of the NBI DT will be $223.2 \mathrm{GBq}(1.86 \times 120=223.2)$. This value is between $370 \mathrm{MBq}$ and $370 \mathrm{GBq}$. That means the tank will fall into the N3 category as defined in ESPN.

For the Pressure Hazard classification, the NBI DT is classified as Category 0. Figure 21 shows details.

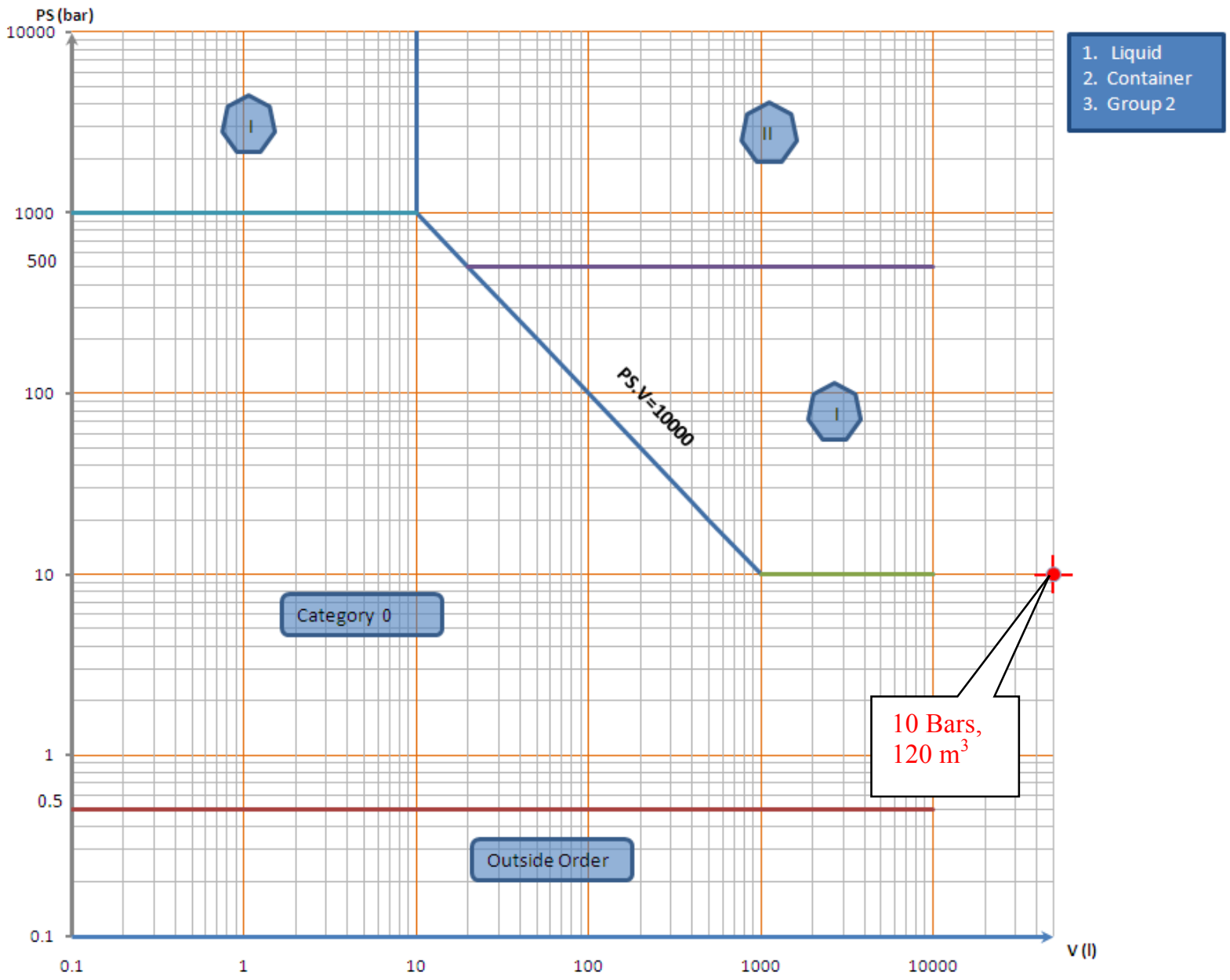

Fig. 21. Classification for the NBI drain tank.

To conclude, the NBI DT is classified as Nuclear Level N3, Pressure Category 0.

\subsubsection{Sump Tank (One Tank)}

The total radioactivity of the sump DT will be $37.8 \mathrm{GBq}(9.45 \times 4=37.8)$. This value is between $370 \mathrm{MBq}$ and $370 \mathrm{GBq}$. That means the tank will fall into the N3 category as defined in ESPN.

For the Pressure Hazard classification, the sump DT is classified as Category 0. Figure 22 shows details. 


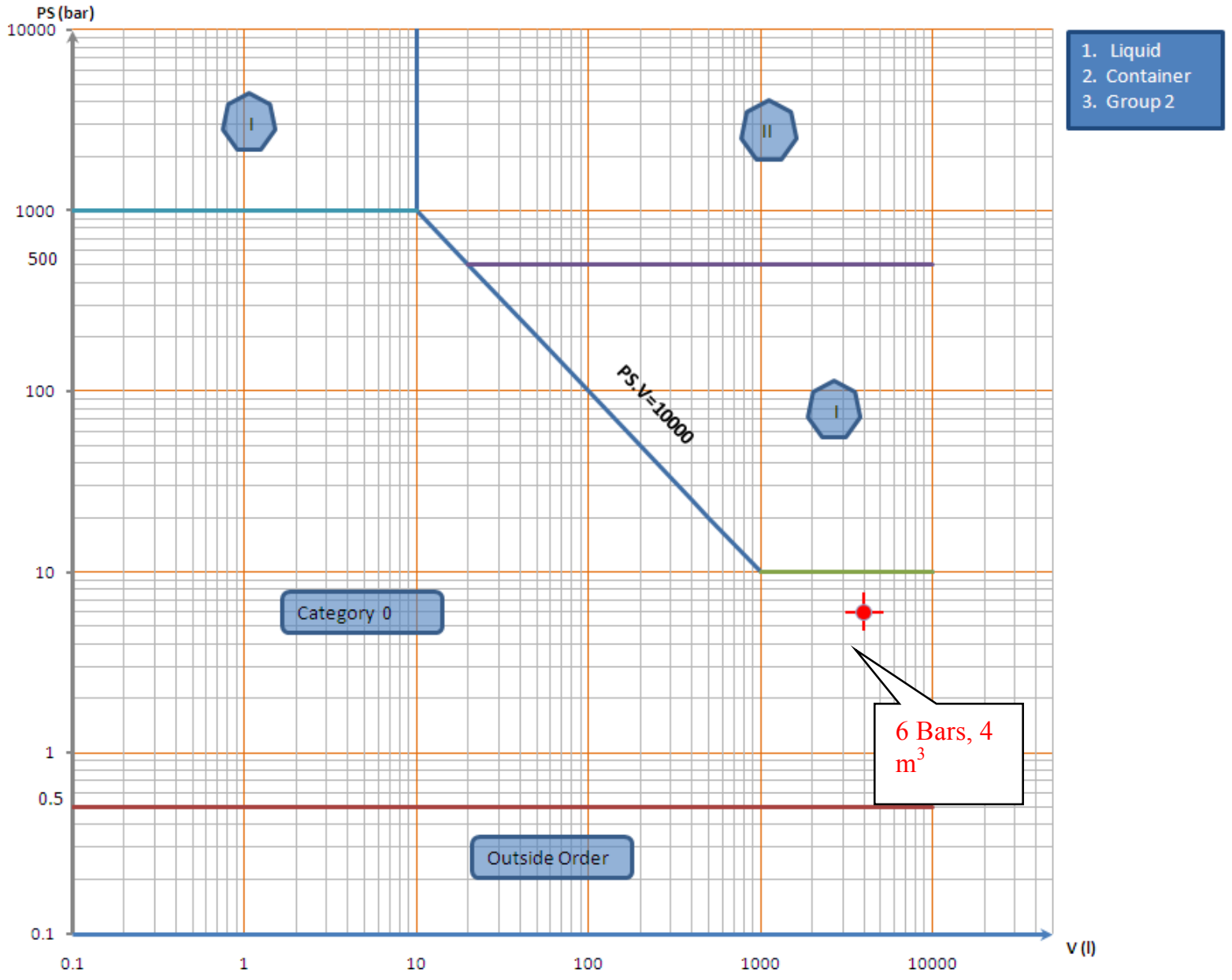

Fig. 22. Classification of the sump tank.

To conclude, the sump DT is classified as Nuclear Level N3, Pressure Category 0. Table 5 summarizes the classification of all tanks.

Table 5. Tokamak Cooling Water System-Draining and Refilling System

\begin{tabular}{|l|l|l|c|c|l|}
\hline PBS & \multicolumn{1}{|c|}{$\begin{array}{c}\text { Equipment and } \\
\text { description }\end{array}$} & \multicolumn{1}{|c|}{ Fluid } & $\begin{array}{c}\text { ESPN } \\
\text { Nuclear } \\
\text { Level }\end{array}$ & $\begin{array}{c}\text { ESPN } \\
\text { Pressure } \\
\text { Category }\end{array}$ & Comments \\
\hline 26 & $\begin{array}{l}\text { DT } \\
\text { Vertical }\end{array}$ & $\begin{array}{l}\text { Pressurized water, } \\
\text { ESP: liquid, Group 2 }\end{array}$ & N2 & I & 2 tanks \\
\hline 26 & $\begin{array}{l}\text { Safety DT } \\
\text { Vertical }\end{array}$ & $\begin{array}{l}\text { Pressurized water, } \\
\text { ESP: liquid, Group 2 }\end{array}$ & N2 & I & 2 tanks \\
\hline 26 & $\begin{array}{l}\text { NBI DT } \\
\text { Vertical }\end{array}$ & $\begin{array}{l}\text { Pressurized water, } \\
\text { ESP: liquid, Group 2 }\end{array}$ & N3 & 0 & 1 tank \\
\hline 26 & $\begin{array}{l}\text { Sump Tank } \\
\text { Vertical }\end{array}$ & $\begin{array}{l}\text { Pressurized water, } \\
\text { ESP: liquid, Group 2 }\end{array}$ & N3 & 0 & 1 tank \\
\hline
\end{tabular}




\subsubsection{Rational for the Classification of the Fluid}

The rationale for the classification of the fluids comes from a communication between Thierry Jourdan, QA Engineer Tritium, Quality Assurance Division, IO and Vladimir Barabash, Senior Technical Officer, System Analysis and Standard Section of IO. ${ }^{14}$ The email confirms that according to French Decree 991046 and an ESPN order dated December 12, 2005, the fluids which must be classified as dangerous fluids (group 1) are

- explosive,

- highly inflammable,

- easily inflammable,

- inflammable (when the maximum acceptable temperature is greater than the flash point),

- very toxic,

- toxic, and/or

- combustive.

The other fluids must be classified as group 2 fluids (nondangerous).

Therefore, water with radioactivity is considered a group 2 fluid, (nondangerous), whatever the level of radioactivity.

Nevertheless, if a piece of equipment which contains water with radioactivity is N2, the fluid is group 2, but for the classification of this equipment, the charts for dangerous fluid (group 1) shall be used [articles 4 a) and b) of the ESPN order and Chapter 2.3, Table A of ASN guide 8, version 1, of March 31, 2009].

Even though there are no official references, Table A of Chapter 2.3 of ASN guide 8 (version 1 of March 31,2009 ) shows for level N3 several tables apply that are related to fluid group 1 and 2 . If a fluid group 2 which contains radioactivity should be considered as fluid group 1, this table would not be necessary.

\subsection{DRAIN TANK REQUIREMENTS FROM SYSTEM REQUIREMENTS DOCUMENT 26}

DTs are instrumented to deliver tank level information and activate a high level alarm, both locally and in the control room.

The SRD does not contain any specific requirements about normal operation DTs. The requirements for safety DTs were described in Sect. 3.4.

\subsection{CHEMICAL COMPOSITION OF DRAIN WATER}

\subsubsection{Normal Operations}

Water drained into the DTs will have radioactive components. Table 6 gives the current reference radioactivity concentration values for the ITER components and cooling loops. ${ }^{15}$

Table 6. Coolant activation concentration for various ITER components and cooling systems

\begin{tabular}{|c|c|c|c|c|}
\hline \multirow{2}{*}{ Source of radioactivity } & \multirow{2}{*}{$\mathbf{V V}$} & FW/BLK & DIV & NB \\
\hline & & \multicolumn{3}{|c|}{$\mathrm{GBq} / \mathrm{m}^{3}$} \\
\hline Tritium $(\mathrm{T})$ - diffusion from plasma chamber & 36 & 1,800 & 1,800 & 1,800 \\
\hline $\mathrm{T}$-from borated steel (= to content) & 40 & - & - & \\
\hline
\end{tabular}




\begin{tabular}{|c|c|c|c|c|}
\hline \multirow{2}{*}{ Source of radioactivity } & \multirow{2}{*}{$\mathbf{V V}$} & FW/BLK & DIV & NB \\
\hline & & \multicolumn{3}{|c|}{$\mathrm{GBq} / \mathrm{m}^{3}$} \\
\hline${ }^{14} \mathrm{C}(=$ content $)$ & $1.0 \mathrm{E}-02$ & 1.0 & 1.0 & $1.0 \mathrm{E}-02$ \\
\hline $\begin{array}{l}\text { Activated corrosion products (ACP) solute }+ \\
\text { cruds }\end{array}$ & $6.65 \mathrm{E}-2$ & 6.65 & 4.84 & $4.84 \mathrm{E}-2$ \\
\hline Activity of coolant due to ${ }^{16} \mathrm{~N}$ isotopes ${ }^{a}$ & $5.62 \mathrm{E}+3$ & $3.0 \mathrm{E}+6$ & $1.85 \mathrm{E}+6$ & $4.0 \mathrm{E}+3$ \\
\hline Activity of coolant due to ${ }^{17} \mathrm{~N}$ isotopes ${ }^{a}$ & 1.69 & $1.7 \mathrm{E}+3$ & $0.66 \mathrm{E}+3$ & 4.0 \\
\hline \multicolumn{5}{|l|}{ Total fluid radioactivity concentration: } \\
\hline $\mathrm{T} / 1000+{ }^{14} \mathrm{C}+\mathrm{ACP}+{ }^{17} \mathrm{~N}+\left({ }^{16} \mathrm{~N}\right) / 1000^{b}$ & $7.46 \mathrm{E}+0$ & $4.71 \mathrm{E}+03$ & $2.52 \mathrm{E}+03$ & $9.86 \mathrm{E}+0$ \\
\hline
\end{tabular}

${ }^{a}$ This concentration is the maximum value of the fluid in the corresponding component.

${ }^{b}$ It is assumed that the coefficient of $1 / 1000$ is applied for activity of ${ }^{16} \mathrm{~N}$ only, as for tritium and some other isotopes in ESPN. Activity of ${ }^{17} \mathrm{~N}$ isotope is included without reduction coefficient.

\subsubsection{Safety Drain Operations}

The functional requirements of the safety DTs are shown in Appendix A. The requirement of the activity of water collected in the tank is as follows: water collected in the safety DTs from TCWS could have maximum fluid radioactivity concentration of $6.65 \mathrm{GBq} / \mathrm{m}^{3}$ due to activated corrosion products (ACP) and $1.8 \mathrm{E}+03 \mathrm{GBq} / \mathrm{m}^{3}$ due to tritium. During a LOCA event, $330 \mathrm{~m}^{3}$ of water is expected to be collected in the tanks, which will contain heavily activated dusts and tritium codeposited in the dust.

The dust transferred during a LOCA event in the expected $330 \mathrm{~m}^{3}$ water collected in the tanks will have beryllium, tungsten, and tritium codeposited in the dust. The total inventory of in-vessel heavily activated dusts is not expected to exceed $1,000 \mathrm{~kg}$. The total mobilized tritium inventory in VV is $1,000 \mathrm{~g}$. About $221 \mathrm{~kg}$ of dust, $28 \mathrm{~kg}$ of ACP, and $20 \mathrm{~g}$ of tritium will be transported in the safety DTs in case of a LOCA.

\subsection{DESIGN CODE AND MATERIALS OF CONSTRUCTION}

The DTs are assumed to be manufactured in stainless steel 304L. The DTs, which are considered pressure equipment for the TCWS, shall be designed and constructed in accordance with the codes and standards as established in the Codes and Standards for ITER Mechanical Components. ${ }^{16}$

Stainless Steel 316 can also be used to construct the DTs. However, the use of this material can only be recommended where there is a clear cost advantage due to the market price of the metal.

\subsection{SEISMIC ANALYSIS}

IO has performed seismic analysis of the B2 level where the DTs will be located. ${ }^{17}$ It is important that AREVA analyzes this report and is familiar with its contents. It is already uploaded in the "Information Only" area of the U.S. ITER SharePoint, but an extract of its salient points follows.

\subsubsection{The Level B2 Spectrum Locations}

The Level B2 spectrum locations are shown in Fig. 23. 


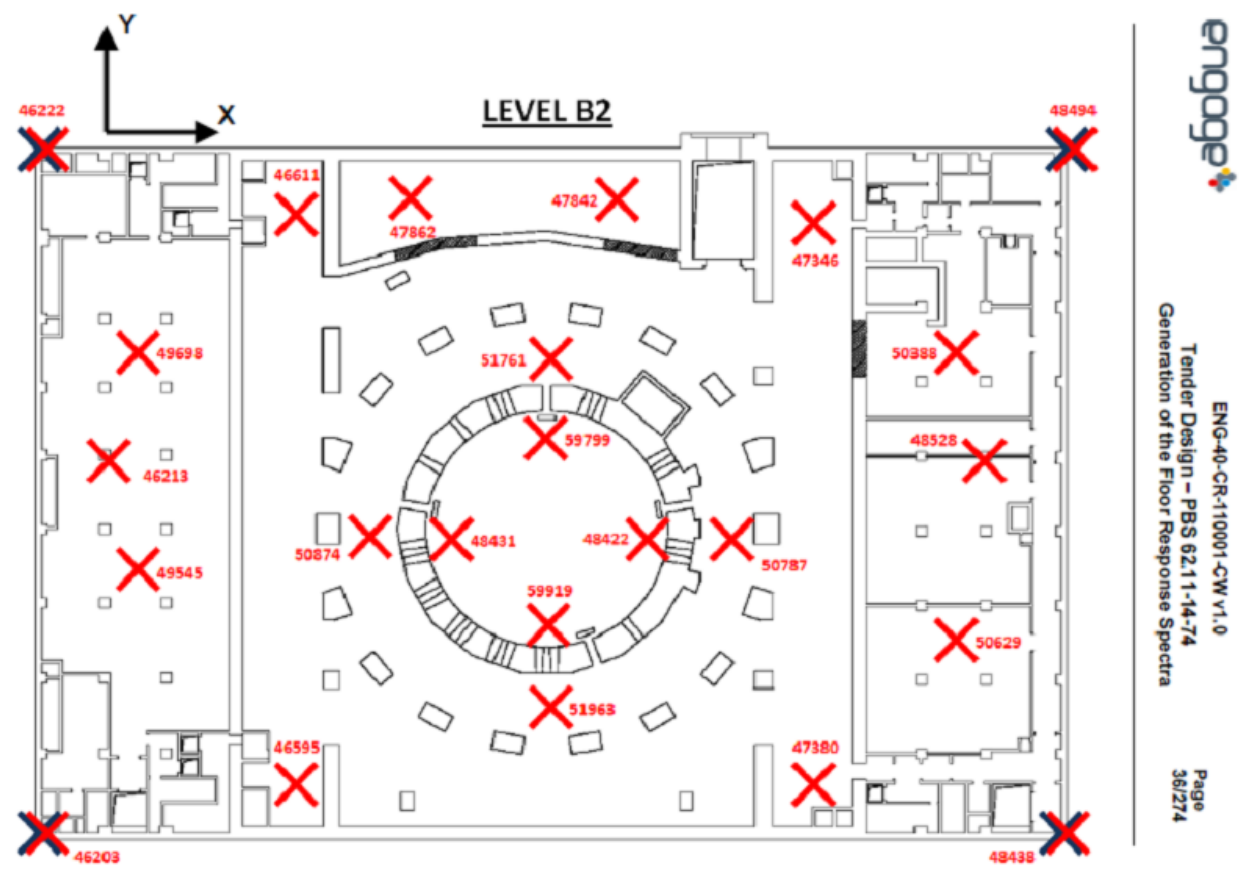

Fig. 23. Level B2 spectrum locations.

The relevant spectra for the seismic analysis of the DTs correspond to locations 47862, 47842, 46222, 48494, 46203, and 48438. From the locations on the two adjacent corners of the DT area on the B2 level we have the $\mathrm{X}$ and $\mathrm{Y}$ (Figs. 24 to 27) from where the seismic analysis for the DTs should select the highest value from the two X and Y direction spectra. Spectra for locations 47862 and 47842 within the DT area have the floor response for direction Z (Figs. 28 and 29). There is no response in the $\mathrm{X}$ and $\mathrm{Y}$ directions because it is assumed to be an isolated pad.

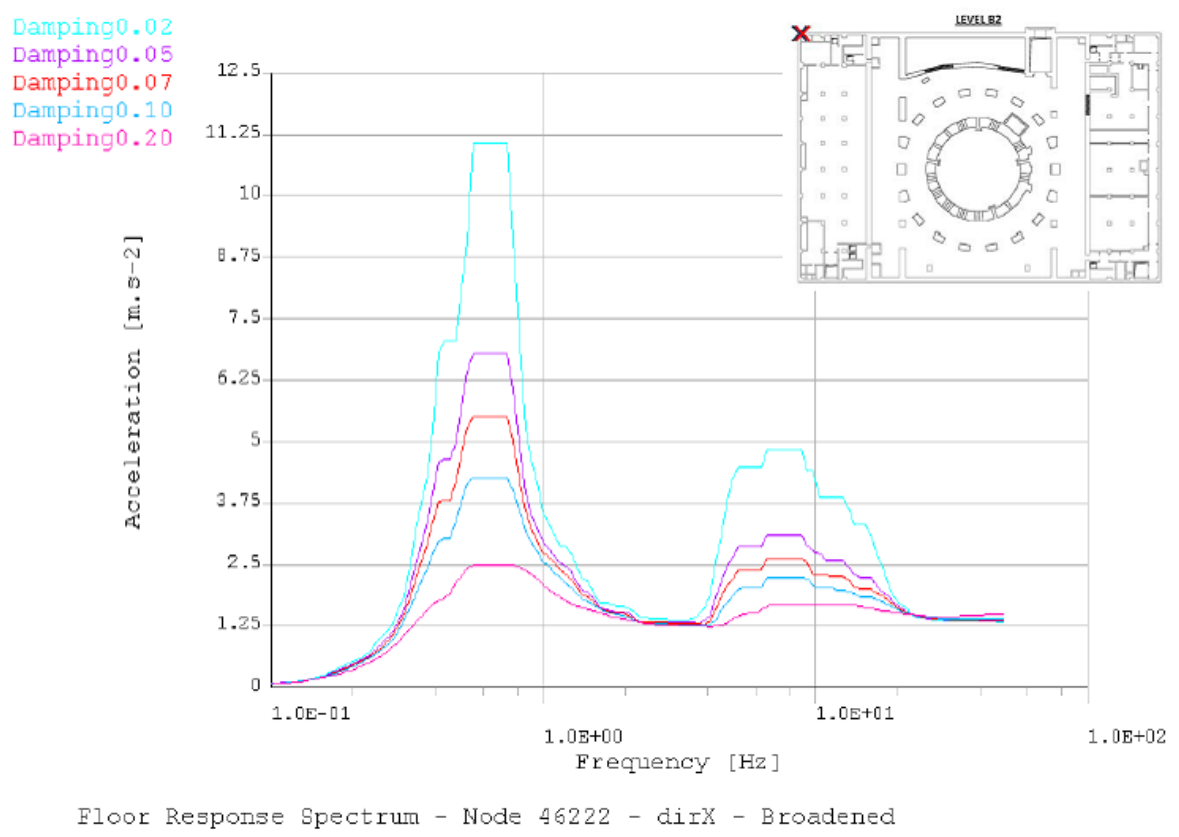

Fig. 24. Floor response spectra (Node 46222), direction $X$ broadened. 


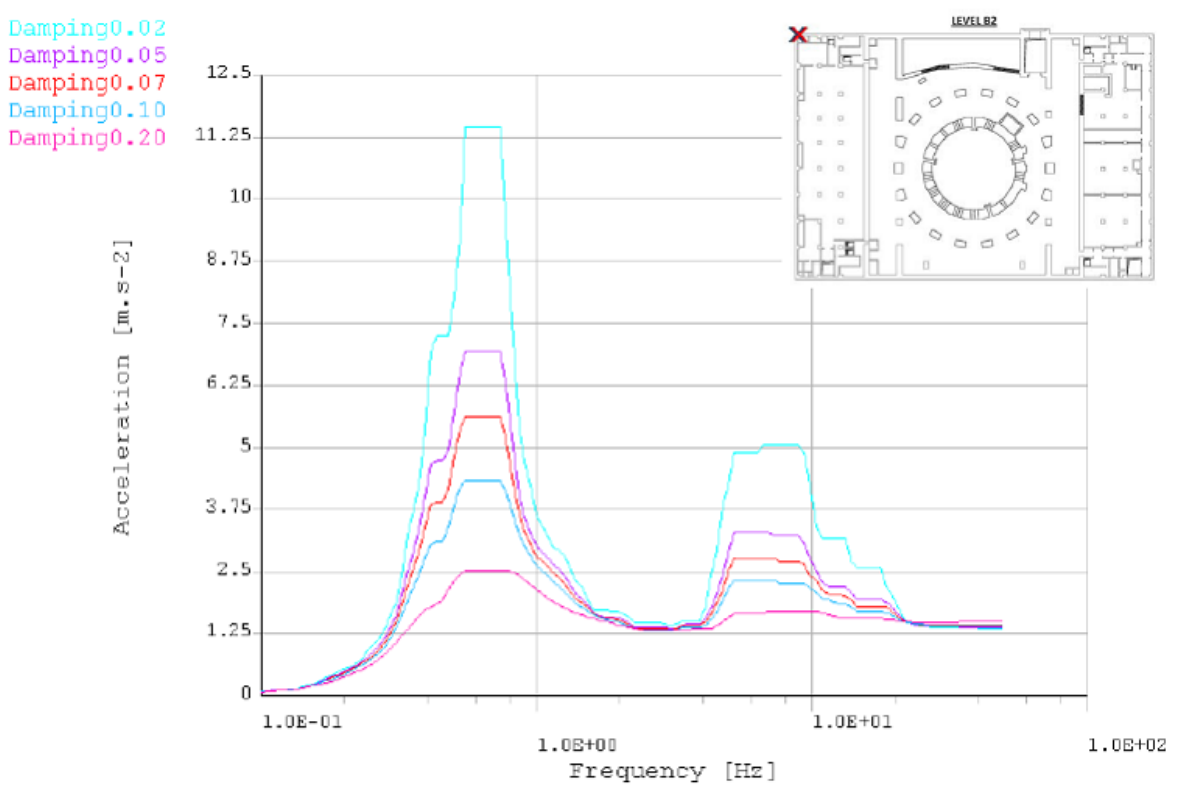

Floor Response Spectrum - Node 46222 - dirY - Broadened

Fig. 25. Floor response spectra (Node 46222), direction Y broadened.

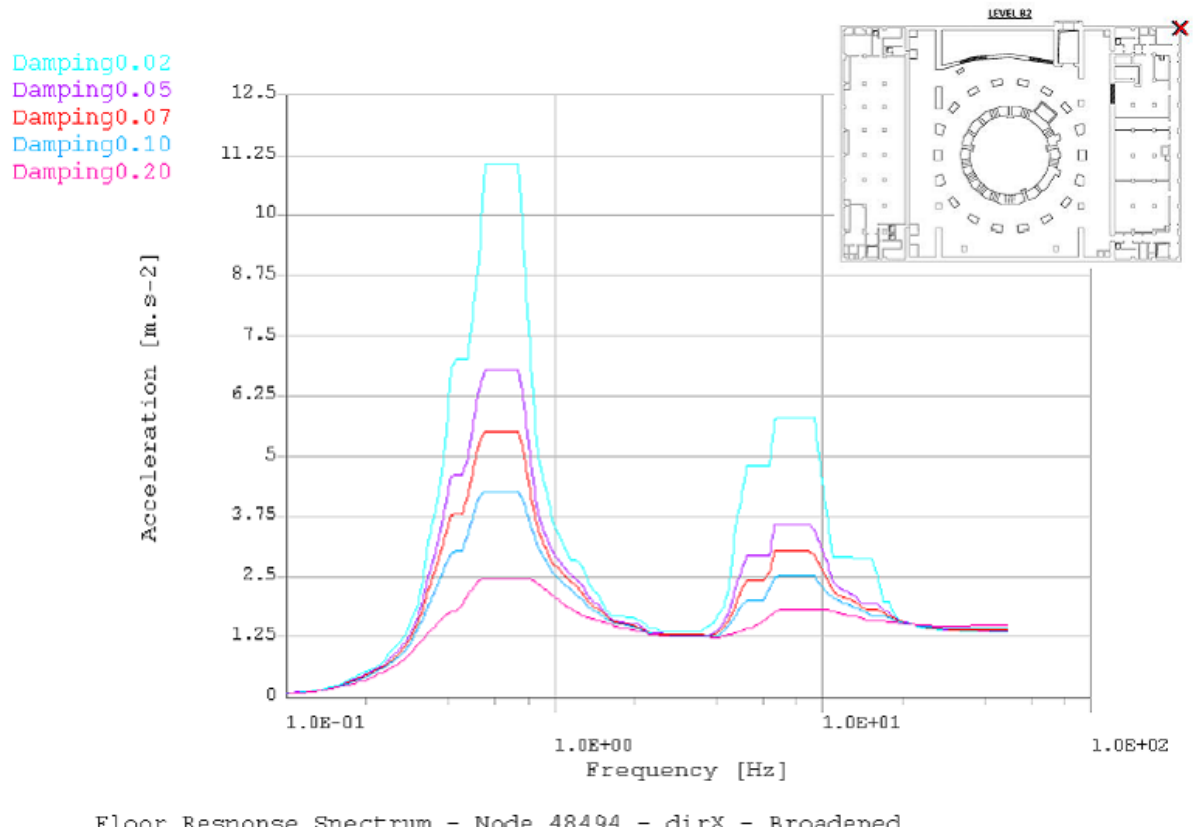

Floor Response Spectrum - Node 48494 - dirX - Broadened

Fig. 26. Floor response spectra (Node 48494), direction X broadened. 


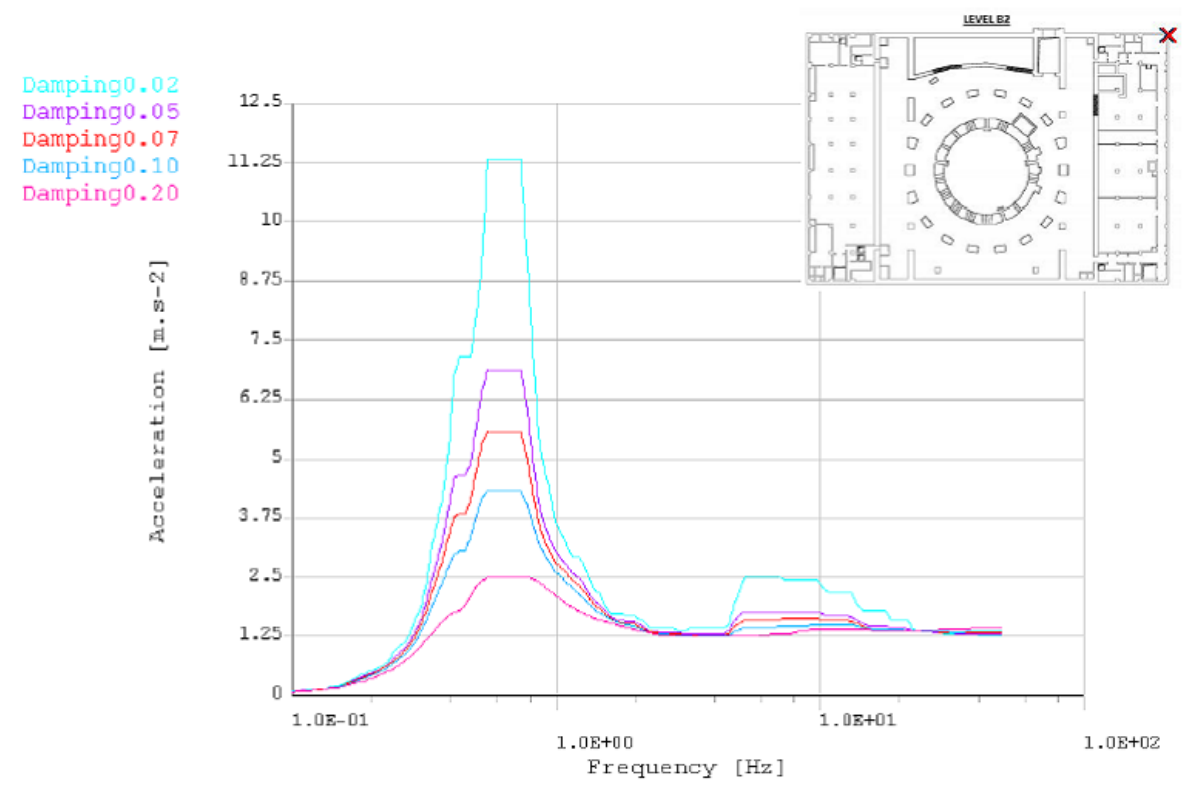

Floor Response Spectrum - Node 48494 - dirY - Broadened

Fig. 27. Floor response spectra (Node 48494), direction Y broadened.

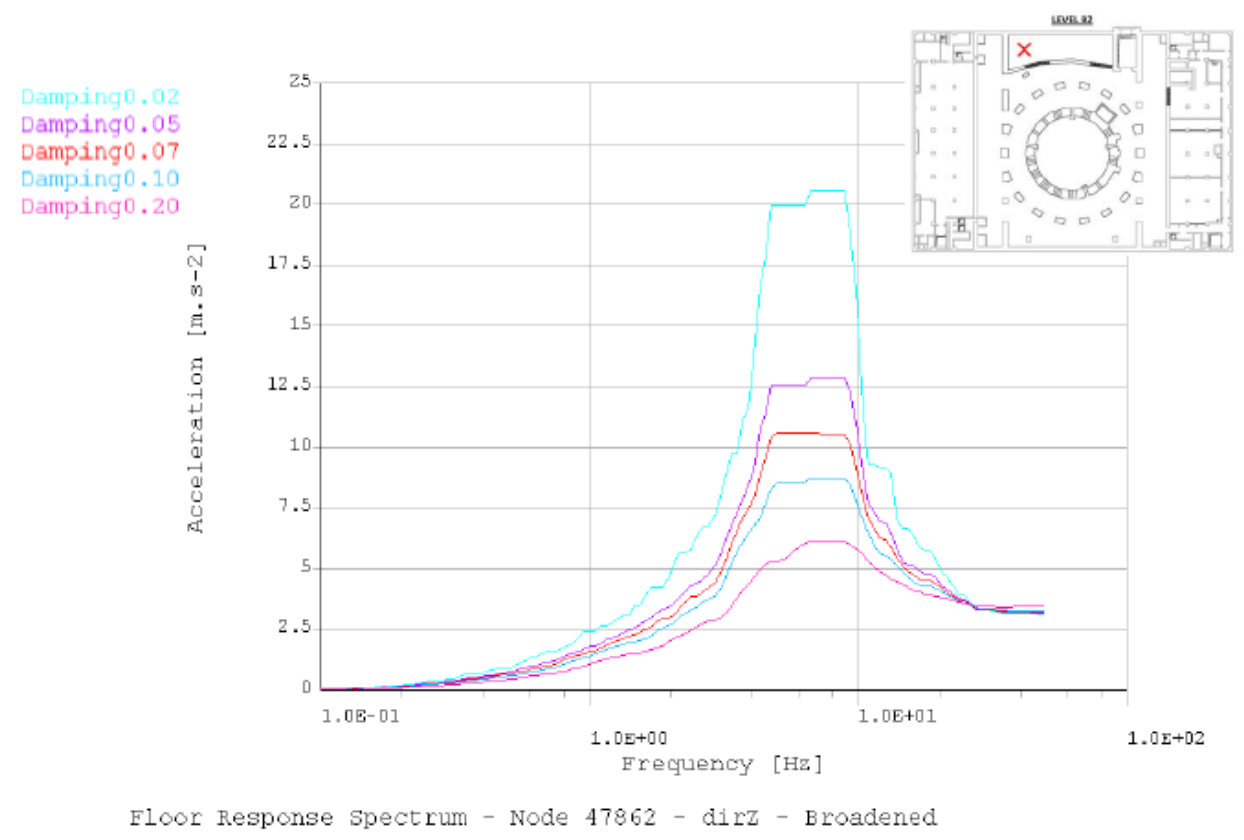

Fig. 28. Floor response spectra (Node 47862), direction $Z$ broadened. 


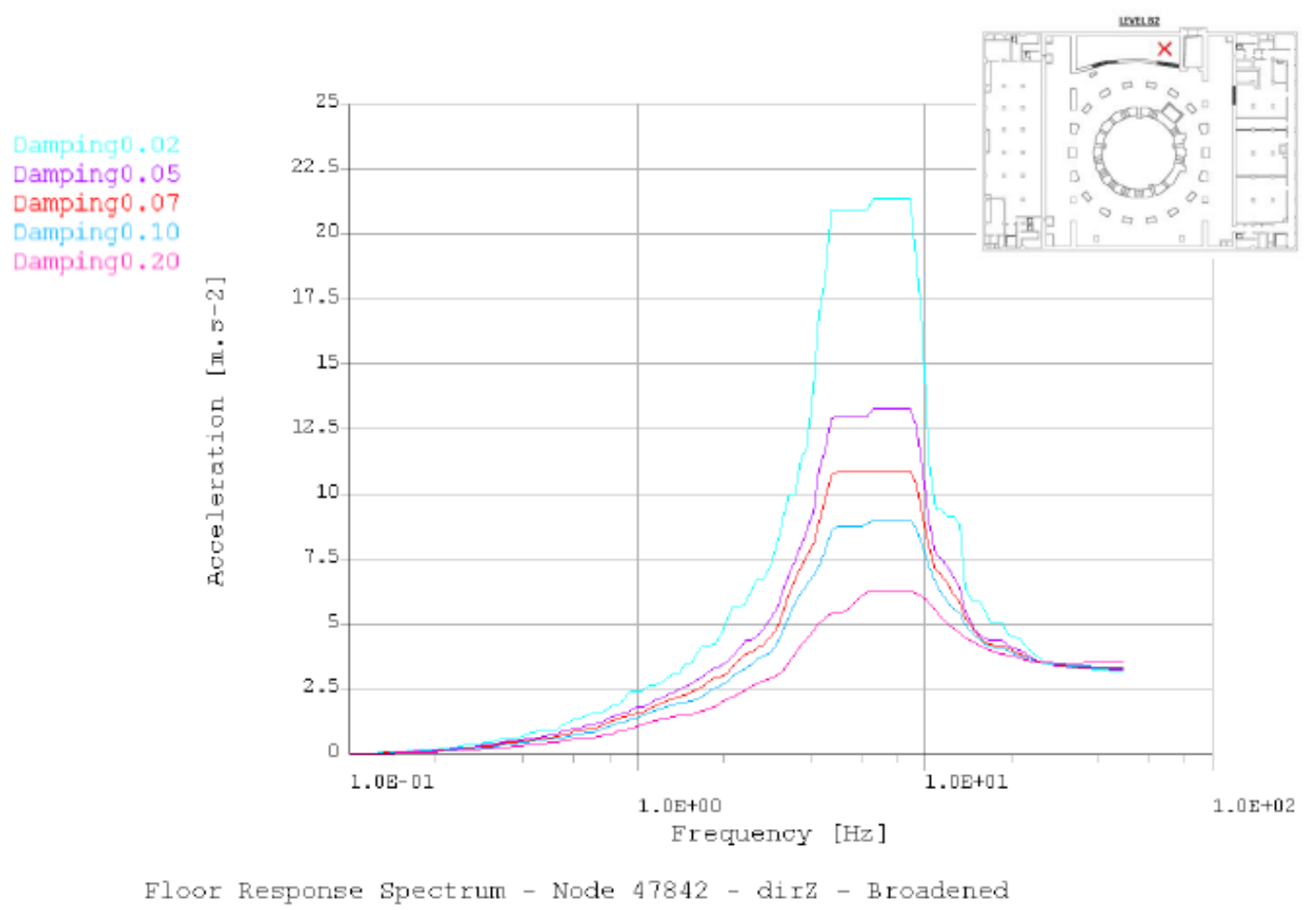

Fig. 29. Floor response spectra (Node 47842), direction $Z$ broadened.

\subsubsection{Seismic Design and Classification}

The seismic design of equipment is based on functional safety requirements in the event of an earthquake for operational or maintenance states, conditions following an accident, or other abnormal facility states. ${ }^{18}$ These requirements concern the following points:

- maximum displacement (e.g. interaction between VV and toroidal field coils),

- integrity of geometric characteristics and degree of permanent deformation,

- leakage,

- operating capability of mechanical or electrical equipment (valves, pumps, circuits, etc.) of systems to perform a safety function, and

- adequacy of shielding.

Components and structures are classified to facilitate the design process. The seismic classification principle is based on the safety objective and functional requirements in the event of an earthquake. The seismic classes defined are as follows.

- $\mathrm{SC} 1$ (SF) - Seismic class one-SF: Structural stability and required functional seismic safety performance maintained in the event of an earthquake. The respect of this level of requirement guarantees the level of safety as throughout the normal operation of the equipment. Nevertheless, taking into account seismic load characteristics, fatigue is not taken into account. 
- SC1 (S)-Seismic class one-S: Structural stability maintained in the event of an earthquake (i.e., no rupture of piping, no collapse of structures or equipment, limited plastic strain, limited concrete cracking, structural support functions maintained). With this level of requirement, it is possible that a small level of deformation could occur. Consequently, it could be necessary to inspect equipment before reusing it.

- SC2-Seismic class two: Nondamage to safety important components (SIC); absence of damage to SIC for buildings and structures housing and protecting SIC or to buildings that can potentially damage such structures in the event of collapse; no other requirements regarding structural or functional performance in the event of an earthquake.

- NSC-Nonseismic category. No seismic requirements for safety.

A modified extract of the table with seismic classifications for the DT area is shown in Table 7. The DT area is being classified as $\mathrm{SC} 1$.

Table 7. Extract of Annex 1 in ITER_D_2DRVPEv.1.1(modified)

\begin{tabular}{|c|c|c|c|c|c|c|c|}
\hline PBS & System & $\begin{array}{l}\text { Preliminary } \\
\text { assessment of } \\
\text { consequences }\end{array}$ & $\begin{array}{l}\text { Subsystems/ } \\
\text { components }\end{array}$ & SC1 & SC2 & NSC & $\begin{array}{l}\text { Comments and } \\
\text { additional indication } \\
\text { about safety } \\
\text { requirements during } \\
\text { and following SSE } \\
\text { earthquake }\end{array}$ \\
\hline \multirow[t]{2}{*}{2.6} & \multirow[t]{2}{*}{ TCWS } & $\begin{array}{l}\text { - Piping remains } \\
\text { intact } \\
\text { - Plasma heat load } \\
\text { terminated. }\end{array}$ & VV PHTS & $\begin{array}{l}\text { No } \\
\text { leakage }\end{array}$ & & & $\begin{array}{l}\text { Structural stability } \\
\text { maintained with loads } \\
\text { and displacements } \\
\text { within limits to } \\
\text { prevent damage or } \\
\text { deformation of cooling } \\
\text { passages that could } \\
\text { lead to a flow blockage } \\
\text { Loads, strains, } \\
\text { deformation below } \\
\text { limits to ensure no } \\
\text { rupture }\end{array}$ \\
\hline & & $\begin{array}{l}\text { - Piping remains } \\
\text { intact } \\
\text { - Plasma/NB heat } \\
\text { load terminated } \\
\text { - Interruption of } \\
\text { coolant circulation } \\
\text { circuit may occur } \\
\text { due to loss of off- } \\
\text { site power }\end{array}$ & $\begin{array}{l}\text { FW/BLKT } \\
\text { PHTS } \\
\text { DIV/LIM } \\
\text { PHTS } \\
\text { NB PHTS }\end{array}$ & $\begin{array}{l}\text { No } \\
\text { leakage }\end{array}$ & & & $\begin{array}{l}\text { Loads, strains, } \\
\text { deformation below } \\
\text { limits to ensure no } \\
\text { rupture }\end{array}$ \\
\hline
\end{tabular}




\begin{tabular}{|c|c|c|c|c|c|c|c|}
\hline PBS & System & $\begin{array}{l}\text { Preliminary } \\
\text { assessment of } \\
\text { consequences }\end{array}$ & $\begin{array}{l}\text { Subsystems/ } \\
\text { components }\end{array}$ & SC1 & $\mathrm{SC2}$ & NSC & $\begin{array}{l}\text { Comments and } \\
\text { additional indication } \\
\text { about safety } \\
\text { requirements during } \\
\text { and following SSE } \\
\text { earthquake }\end{array}$ \\
\hline & & $\begin{array}{l}\text { - Coolant } \\
\text { discharge into } \\
\text { Relief Tank if any } \\
\text { short-time } \\
\text { pressure rise } \\
\text { - Minor increase } \\
\text { in leakage may } \\
\text { occur (e.g., from } \\
\text { fittings)—-no } \\
\text { TCWS vault } \\
\text { pressure increase }\end{array}$ & $\begin{array}{l}\text { Coolant } \\
\text { discharge } \\
\text { system into } \\
\text { Relief Tank }\end{array}$ & Function & & & $\begin{array}{l}\text { Loads, strains, } \\
\text { deformation below } \\
\text { limits to ensure no } \\
\text { rupture } \\
\text { I\&C for detection and } \\
\text { operation functional }\end{array}$ \\
\hline & & $\begin{array}{l}\text { - Piping remains } \\
\text { intact } \\
\text { - Minor increase } \\
\text { in leakage may } \\
\text { occur (e.g., from } \\
\text { fittings) }\end{array}$ & $\begin{array}{l}\cdot \text { CVCS } \\
\cdot \text { Draining \& } \\
\text { Refilling } \\
\text { System } \\
\text { - Drying } \\
\text { System }\end{array}$ & $\begin{array}{l}\text { No } \\
\text { leakage }\end{array}$ & & & $\begin{array}{l}\text { Loads, strains, } \\
\text { deformation below } \\
\text { limits to ensure no } \\
\text { rupture }\end{array}$ \\
\hline & & $\begin{array}{l}\text { - Failures may } \\
\text { occur, but no } \\
\text { flooding leading } \\
\text { to damage to SIC }\end{array}$ & $\begin{array}{l}\text { - Component } \\
\text { cooling water } \\
\text { - Chilled } \\
\text { water system } \\
\text { (non-SIC) } \\
\text { - Heat } \\
\text { rejection } \\
\text { system }\end{array}$ & & & $\mathrm{X}$ & $\begin{array}{l}\text { Assess consequential } \\
\text { damage (pipewhip, } \\
\text { flooding etc.) and } \\
\text { design to prevent } \\
\text { damage to SIC. }\end{array}$ \\
\hline
\end{tabular}

\subsection{DRAIN TANK TEMPORARY STORAGE}

The IO CCS Building Group has advised that to date they or F4E, an IO architecture-engineering company, have not documented any special requirements for temporary storage on site. However, at this stage IO would suggest that any weathering or protection required to preserve the integrity of the tanks should be put in place by the U.S. domestic agency (DA). Stability issues with regard to wind loads while stored on site need to be considered. If necessary, recommendations made or temporary measures included by U.S. DA-U.S. ITER should suggest the proper and unique protection methods required to preserve the integrity of the DTs, both during transportation and during possible temporary storage at the ITER site. ${ }^{19}$

Based on this information AREVA should consider suggesting appropriate protection for the tanks while being transported and stored on site when no special IO temporary storage measures are in place. 


\section{GENERAL COMMENTS}

In the course of writing this report, several meetings and conference calls have occurred for clarifying the input information for the design basis of the DTs. Appendix C includes a table with questions asked by AREVA and answers given by U.S. ITER. These answers reflect a compilation of responses from U.S. ITER and IO.

The DTs should be designed for 40 years according to IO. IO has also suggested removing permanent piping connection between safety tanks and other TCWS DTs to avoid inadvertent cross contamination from highly contaminated water from safety DTs to other DTs. AREVA needs to analyze these suggestions and propose a solution.

IO has prepared the document" Functional Requirements for the Safety Drain Tanks" that has been fully approved by IO. This document answers many of the questions asked by AREVA with respect to the functional requirements of the safety DTs and has been included in Appendix A for AREVA's benefit. As this is an approved document, it also constitutes a design input document for the DT design.

The DT classification also has not been signed by all the approvers in IO. Consequently, the current classification of the DTs shown in Sect. 3.8 of this document is not final.

The Drain Tanks (2 normal operation, 2 safety, sump and NBI) are classified as follows:

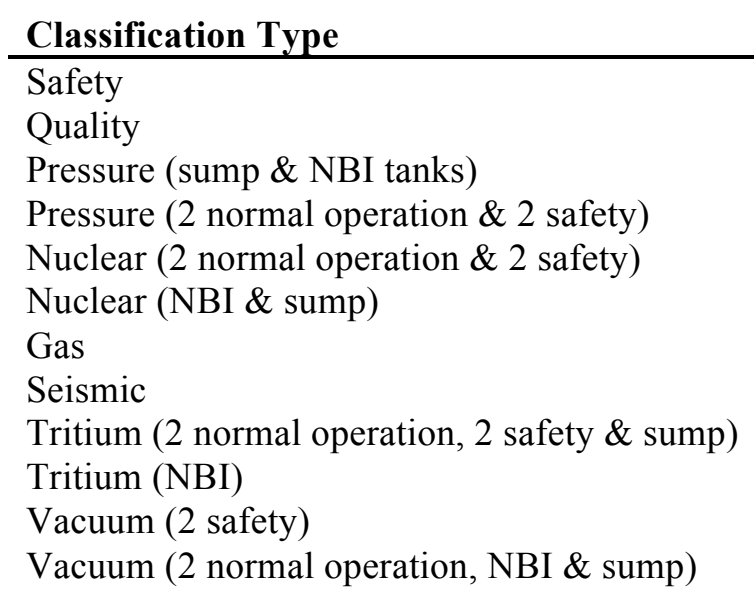

\begin{tabular}{l} 
Classification Level \\
\hline SIC 2 \\
1 \\
SEP/0 \\
1 \\
2 \\
3 \\
Group 2 \\
SC1 \\
T4A \& T4B \\
N/A \\
VQC3X \\
N/A
\end{tabular}





\section{REFERENCES}

1. "Influence of the drain tank geometry and location on the water drainage in case of multiple FW/BLK in-vessel pipe break," Leonid Topilski, ITER-D_34T2C9 v 1.0, August 25, 2010.

2. Final Report Phase 1, Washington Group; Final Report for Task 3 Cooling Water System Optimization Study, Tractebel.

3. "RELAP5 Model of the Vacuum Vessel Primary Heat Transfer System," J. Carbajo, G. Yoder, and S. Kim, U.S. ITER 12103-TD0062-R00, May 2010.

4. "Modifications to the VV PHTS RELAP5 Model" (Draft), J. Carbajo, U.S. ITER 12103-TD0004R00, August 2010.

5. "Influence of the drain tank geometry and location on the water drainage in case of multiple FW/BLK in-vessel pipe break," Leonid Topilski, ITER-D_34T2C9 v 1.0, August 25, 2010.

6. Leonid Topilski, email to Giovanni Dell'Orco, 2009.

7. "Influence of the drain tank geometry and location on the water drainage in case of multiple FW/BLK in-vessel pipe break," Leonid Topilski, ITER_D_34T2C9 v 1.0, August 25, 2010.

8. Trip report, 26 August-5 September 2009, Cadarache, France, Jan Berry and Juan Ferrada.

9. Email from Giovanni Dell'Orco to Juliano Rigoni, January 4, 2010.

10. "System description of the draining drying and refilling systems for PHTS loops, Tractebel, TIERSDI-4NG-3400-03," 2001.

11. Preliminary input temperature of $50^{\circ} \mathrm{C}$ has been considered in the past, but it has to be $<=100^{\circ} \mathrm{C}$ with operational margin to be determined during preliminary design by AREVA.

12. ITER_D_24D8R5 v1.0 - Order-December 31, 1999, amended 01/2006 design of INB and hazard on environment EN.

13. List of ITER Nuclear Pressure Equipment, ITER_D_34MZKE, January 18, 2010.

14. Email between Thierry Jourdan, QA Engineer Tritium, Quality Assurance Division, ITER Organization and Vladimir Barabash, Senior Technical Officer, System Analysis and Standard Section of ITER Organization. October 4, 2010.

15. Fluid Radioactivity Concentration for the ITER Tokamak Cooling Water System, ITER_D_26GLXV v2.4, January 4, 2010.

16. Codes and Standards for ITER Mechanical Components (ITER_D_25EW4K).

17. Tender Design - TOKAMAK Complex, PBS 62.11, PBS 62.14 AND PBS 62.74, Generation of the Floor Response Spectra, ENG-40-CR-110001-CW v 1.0, ITER Organization, ENGAGE, 9/10/2010.

18. ITER Seismic Nuclear Safety Approach, ITER_D_2DRVPEv.1.1, September 18, 2008.

19. Email from Ring William (from IO CCS Building) to Jan Berry, September 30, 2010. eDOCS 6022. 

APPENDIX A.

FUNCTIONAL REQUIREMENTS FOR THE SAFETY DRAIN TANKS 



\section{APPENDIX A. FUNCTIONAL REQUIREMENTS FOR THE SAFETY DRAIN TANKS}

\section{Abstract}

This document specifies the functional requirements of the Safety Drain Tanks of the ITER Tokamak Cooling Water System.

\begin{tabular}{|c|c|c|}
\hline & External Number: ITER_D_3YG3ZL & Date: $3^{\text {rd }}$ November 2010 \\
\hline & Name & Affiliation \\
\hline Author & G. Babulal & CEP-PED-CWS \\
\hline \multirow[t]{6}{*}{ Reviewers } & G. Dell'Orco & CEP-PED-CWS \\
\hline & W. Curd & CEP-PED-CWS \\
\hline & P. Cortes & CIE-NSE-SAA \\
\hline & J.Elbez-Uzan & CIE-NSE-SDI \\
\hline & N. Taylor & CIE-NSE \\
\hline & D. Stout & CEP-PED \\
\hline Approver & Y. H. Kim & CEP \\
\hline
\end{tabular}

\section{Revisions}

\begin{tabular}{|c|c|c|l|}
\hline $\begin{array}{c}\text { Version } \\
\text { number }\end{array}$ & Date & Chapter & \multicolumn{1}{c|}{ Scope of the revision } \\
\hline $\mathrm{v} 1.1$ & $5-11-2010$ & 7,8 & $\begin{array}{l}\text { The chapters "References" and "Abbreviations" were } \\
\text { renumbered }\end{array}$ \\
\hline $\mathrm{v} 1.2$ & $19-11-2010$ & $3,4,5.5,5.16$ & Comments of the reviewers were incorporated. \\
\hline & & & \\
\hline
\end{tabular}




\section{Table of Contents}

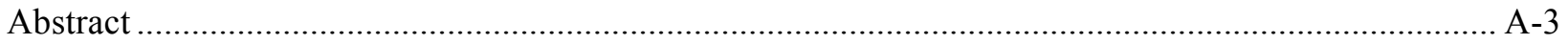

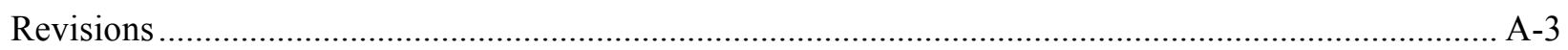

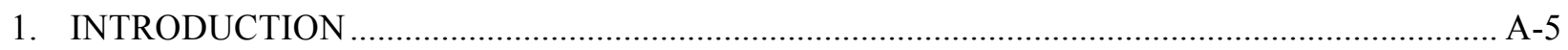

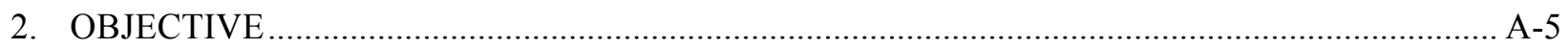

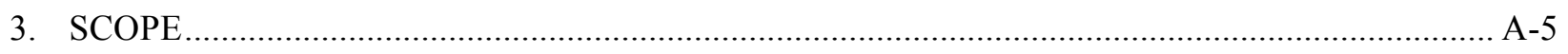

4. ZONING CLASSIFICATION OF DRAIN TANK AREA ............................................................ A-6

5. FUNCTIONAL REQUIREMENTS OF SAFETY DRAIN TANKS .......................................... A-6

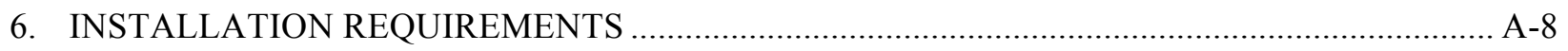

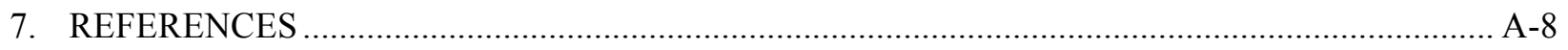

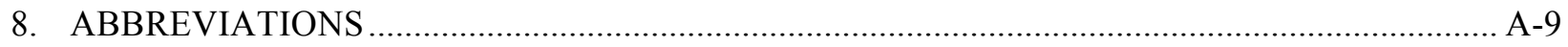




\section{INTRODUCTION}

Draining and Refilling System (DRS) of Tokamak Cooling Water System (TCWS) has total five drain tanks to serve functions during normal operation and safety accidents. Out of these, three drain tanks are designated for normal operation and are used for the storage of coolant during maintenance and inspection, excess coolant from the PHTSs owing to water volume expansion during baking, and residual coolant from forced draining and drying ${ }^{4}$. Two drain tanks are designated as Safety Drain Tanks (SDT) for safety operation to store the inventory of water resulting from the design basis loss of coolant accident of the PHTS that results in a leak into the vacuum vessel (VV) ${ }^{2,4,8}$. These tanks could also be used to drain water from VV PHTS based on operational requirements and the status of the tanks ${ }^{4}$.

During the preliminary design of the Drain tanks, US-ITER has raised some queries with regard to the design requirements of safety drain tanks that are needed to answer the questions of Architect Engineers AREVA, who is engaged in the TCWS preliminary design. A meeting was held with USITER, ITER Safety Section and Cooling Water Section to discuss these issues. Based on the decision taken during the meeting, this document is prepared to indicate the functional requirements for safety drain tanks in order to facilitate the design.

\section{OBJECTIVE}

The objective of this document is to provide relevant information to US-ITER in order to facilitate their Architect Engineers to design the Safety Drain Tanks meeting all functional requirements. The design of the Safety Drain Tanks should meet the requirements indicated in this document in addition to the requirements specified in the relevant baseline documents like SRD, DDD, PR etc.

\section{SCOPE}

The scope of the document is to specify the requirements of the Safety Drain Tanks that are to be considered during its design. The requirements that need to be defined are as follows:

- Identify the factors that impact the design of Safety Drain Tanks

- Quantity of dust transferred after LOCA inside VV to the Safety Drain tanks

- Quantity of activated corrosion products (ACP) and Tritium content of water collected inside the Safety Drain Tank.

- Impact of the contaminated water on the zoning, in particular radiological, ventilation and waste zoning of the area.

- Level of residual contamination of the Drain Tanks after cleaning

- Cleaning features that are to be incorporated in the Safety Drain Tanks for decontaminating the tanks after discharging the contaminated water collected during an in-vessel leak.

- Features in the tank for discharging the contaminated water. 


\section{ZONING CLASSIFICATION OF DRAIN TANK AREA}

The safety drain tanks are located in the Tokamak Building room number 11-B2-01 and 11-B1-01. The RPrS provides the zoning classification of the drain tank room.

During operating mode (plasma phase), Tokamak building is classified as an orange zone (dose rate < $100 \mathrm{mSv} / \mathrm{h}$ ) and access is not allowed.

During shutdown phase, the area is classified as Yellow zone (Dose equivalent rate $<2 \mathrm{mSv} / \mathrm{h}$ ) and as a $\mathrm{C} 2$ zone with regard to the ventilation zoning (permanent contamination in the room $<1 \mathrm{DAC},<80$ DAC for accidents). The room is permanently served by HVAC systems and on a stand-by mode by detritiation systems ${ }^{7,11}$.

The waste zoning of this room is a nuclear waste zone and the beryllium zone corresponds to a non beryllium zone.

During maintenance, physical measures (such as interlocks, wearing of protective clothing, etc.) and/or administrative measures (warning signs, sound messages, etc.) will be set up to restrict access to rooms that have a dose rate higher than the green zone limit or a atmospheric contamination greater than 1 DAC.

\section{FUNCTIONAL REQUIREMENTS OF SAFETY DRAIN TANKS}

5.1 Purpose of Safety Drain Tanks: To store the inventory of water ensuing from the design basis loss of coolant accident that results in a leak into the vacuum vessel (VV). The contaminated water collected in these tanks following an in-vessel water leak shall be sent to Radwaste facility for further processing and disposal.

These tanks could also be used to store water from VV PHTS based on operational requirements and the status of the tanks ${ }^{4}$.

5.2 Number of Safety drain tanks: Two $^{4}$.

5.3 Location: B2 level of Tokamak building ${ }^{10}$.

5.4 Net height available in the area for installing the tanks: $10.6 \mathrm{~m}^{12}$.

5.5 Minimum volume to be accommodated by the 2 tanks: $330 \mathrm{~m}^{3}$ (as per safety analysis by ITER Nuclear Safety Division) $+30 \%$ excess capacity to accommodate for uncertainties of the calculation and free space ${ }^{6}$. But to homogenize the size of these tanks with that of the normal drain tanks of FW/BLK and DIV PHTS ( 2 tanks, each of $\left.270 \mathrm{~m}^{3}\right)$, the construction volume of safety drain tanks should be $540 \mathrm{~m}^{3}$ (2 tanks, each of $270 \mathrm{~m}^{3}$ volume).

5.6 Classification under nuclear pressure equipment: ESPN category N2 ${ }^{9}$.

5.7 Normal operating pressure: $10 \mathrm{kPa}(\mathrm{abs})^{4}$.

5.8 Maximum pressure inside the tank due to design basis accident: $80 \mathrm{kPa}(\mathrm{abs})^{6}$.

5.9 Design pressure taking account of worst operational scenarios: $1 \mathrm{MPa}^{9}$. 
5.10 Venting provision: The tank should have provision at its top to give connection to Normal Vent Detritiation System (NVDS).

\subsection{Maximum operating temperature: $94^{\circ} \mathrm{C}^{6}$}

5.12 Activity of water collected in the tank: Water collected in the SDTs from TCWS could have maximum fluid radioactivity concentration ${ }^{13}$ of $6.65 \mathrm{GBq} / \mathrm{m}^{3}$ due to ACP and $1.8 \mathrm{E}+03 \mathrm{GBq} / \mathrm{m}^{3}$ due to Tritum. During LOCA event, $330 \mathrm{~m}^{3}$ of water is expected to be collected in the tanks, which will contain heavily activated dusts and Tritium co-deposited in the dust.

5.13 Quantity of dust transferred during LOCA: During LOCA event, the expected $330 \mathrm{~m}^{3}$ water collected in the tanks will have heavily activated dusts (such as Beryllium, Tungsten) and Tritium co-deposited in the dust. Total inventory of in-vessel heavily activated dusts is expected not to exceed $1000 \mathrm{~kg}^{11}$. The total mobilized tritium inventory in VV is 1000 grams ${ }^{2}$. About $221 \mathrm{~kg}$ of dust, $28 \mathrm{~kg}$ of ACP and $20 \mathrm{~g}$ of tritium will be transported in the SDTs in case of a LOCA ${ }^{2,6}$.

5.14 Inlet and outlet connections: The tank should have provision for inlet at suitable locations. Outlet nozzle should be at the bottom most elevation to facilitate complete emptying of the tank. The bottom of the tank should be shaped such that the entire water, dust and other particulates collected in the tank can be discharged fully and permit decontamination of the tank.

5.15 Provision for sampling: There should be provision for grab sampling of water collected in the tank without spillage in the area. The sampling line can be located at the discharge line of the tank.

5.16 Provision for decontamination: There should be suitable provision to decontaminate the tanks. Provision for decontamination such as built-in jet nozzles or any other suitable technique should be provided to enable removal of solids and residues from the tank wall surfaces by using high pressure water jetting ${ }^{5}$. The surface finish of these tanks and the design of their internals should facilitate to minimize difficulty of decontamination.

During collection of grab samples, while discharging the contaminated water from the tank, at the time of doing maintenance on the equipment related to the drain tank and during decontamination operation, there could be chances of spread of contamination in the tank room. Adequate health physics procedures will be sufficient to deal with such cases.

The decontamination provision for the SDTs should be sufficient enough to meet zoning regulation of the area and complete emptying of the tank without leaving any solid or liquid contaminants that can violate limiting values of the zoning.

5.17 Special features for discharging the water: Tanks should be designed to allow complete emptying without any accumulation of dust. If necessary; facility should be provided which allows the water content to be agitated in order to keep any solids suspended during discharging of the tank hold up water ${ }^{5}$.

5.18 Instrumentation: Measuring and monitoring instrumentation for level, temperature, pressure and radiation field should be provided on the SDTs. Instrumentation sensors should be installed in such a way that there should not be any connection to the bottom of the tank and any equipment positioned inside the tank should not cause dead zones or accumulation of deposits. Care should be taken that electrical cables are installed in sealed, corrosion resistant protection ducts that can be easily decontaminated ${ }^{5}$. 
5.19 Inspection: There should be provision for internal and external inspection of the tanks. Provision for remote inspection and measurement of radiation fields should be considered. Manholes of suitable size should be provided at the lower and upper side of the tank with leak proof sealing.

5.20 Impact of the contaminated water on the radiation zoning of the area: Since the water collected in the safety drain tanks during LOCA event will have ACPs, tritium, heavily activated dusts and Tritium co-deposited in the dust, which will contribute to the increase in the radiation field of the area around the tanks and could exceed the zoning limits. Suitable temporary shielding provisions as per ALARA principle, if necessary, could be arranged before draining the contaminated water to SDTs. Complete discharging of the collected drains and decontamination can normalize breaches in the zoning limits.

\section{INSTALLATION REQUIREMENTS}

6.1 The design of the safety drain tank should consider the installation requirements. Tank design should consider the use of air pads and temporary brackets to attach air pads for the installation purpose.

6.2 There shall be sufficient space at the top of the tanks to provide vent connection.

6.3 There should be accessibility to the top of the tanks using in built ladder for carrying out inspection and maintenance activities.

\section{REFERENCES}

1. Accident Analysis Report (AAR) Volume I - Event Identification and Selection(ITER_D_2DPVGT v1.4)

2. Accident Analysis Report (AAR) Volume II - Reference Event Analysis (ITER_D_2DJFX3 v4.10)

3. ITER_D_2823A2 v2.1 - SRD-26-PH, -CV, -DR, -DY (TCWS) from DOORS

4. ITER Tokamak Cooling Water System (TCWS) Design Description Document (DDD)(ITER_D_2V3L3R v1.1)

5. IAEA Technical Reports Series No. 401

6. Influence of the drain tank geometry and location on the water drainage in case of multiple FW/BLK in-vessel pipe break (ITER_D_34T2C9 v1.0)

7. Rooms Hazards Environmental Conditions Excel Data (ITER_D_2W9MDE v1.0)

8. Project Requirements (PR)(ITER_D_27ZRW8 v4.6)

9. Modification of TCWS ESPN Classification (ITER_D_35TFL4 v1.0)

10. Tokamak Complex Radiological Zoning Mode 1 and Mode 2 - B2 and B2M(ITER_D_3QQSNU v1.0)

11. Tokamak Complex Radiological Zoning Mode 1 and Mode 2 - B1(ITER_D_3QFG4D v1.0)

12. Tokamak Building - N-S Elevation Drawing(ITER_D_29NALR v1.1 - 621100-CCSQXD-01)

13. Fluid Radioactivity Concentration for the ITER Tokamak Cooling Water System(ITER_D_26GLXV v2.4) 


\section{ABBREVIATIONS}

ACPs Activated Corrosion Products

ALARA As Low As Reasonably Achievable

DAC Derived Air Concentration

DDD Design Description Document

DRS Draining and Refilling System

ESPN Equipements Sous Pression Nucleaires

LOCA Loss of Cooling Accident

NVDS Normal Vent Detritiation System

PR Project Requirements Document

PHTS TCWS Primary Heat Transfer Systems

SDT Safety Drain Tank

SRD System Requirements Document

TCWS Tokamak Cooling Water System

VV Vacuum Vessel 

APPENDIX B.

INTERFACES WITH THE DRAIN TANKS 



\section{APPENDIX B. INTERFACES WITH THE DRAIN TANKS}

Refilling pumps for BLK and DIV drain tanks

If one pump: $80 \mathrm{~m}^{3} / \mathrm{h}$

If two pumps: one of $60 \mathrm{~m}^{3} / \mathrm{h}$ and one for $20 \mathrm{~m}^{3} / \mathrm{h}$

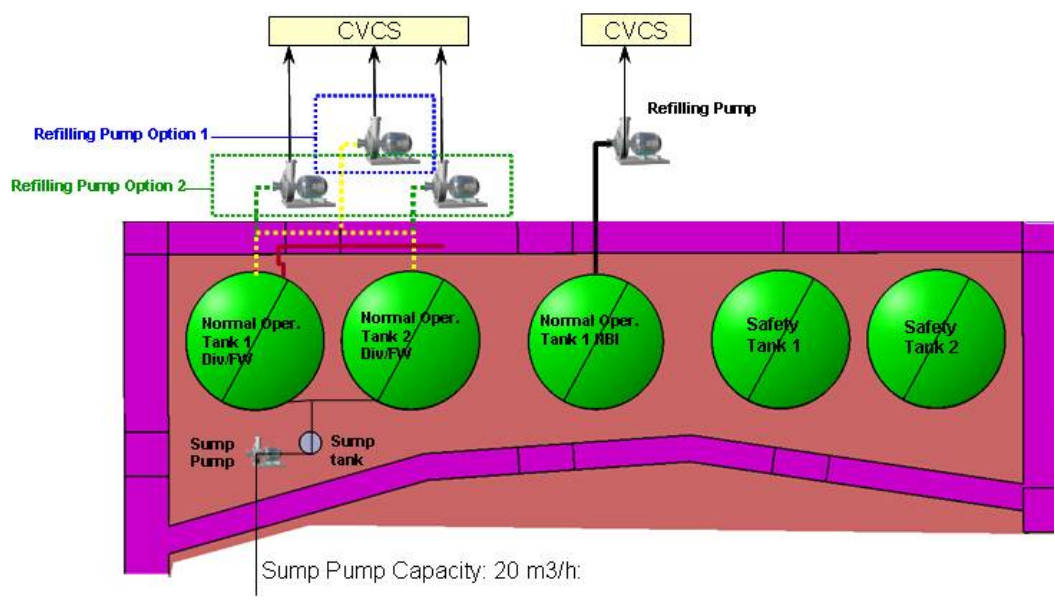

Ref: DDD 262004

Fig. B.1. Refilling pump interfaces.

\section{Liquid waste}

From: ITER TCWS Interface Document Utility Needs, TIERSD/4NG/0004724/000/01

Ed. 030603

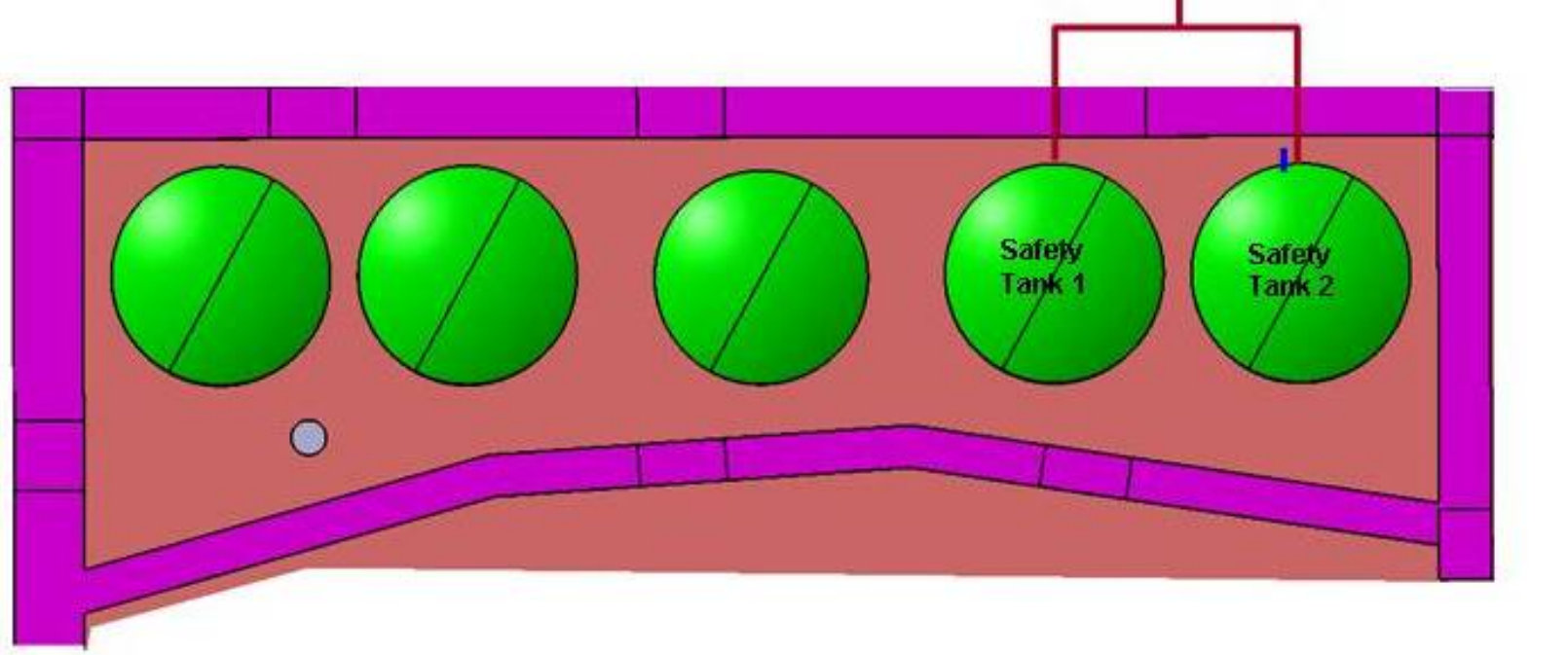

Fig. B.2. Radioactive waste interfaces. 


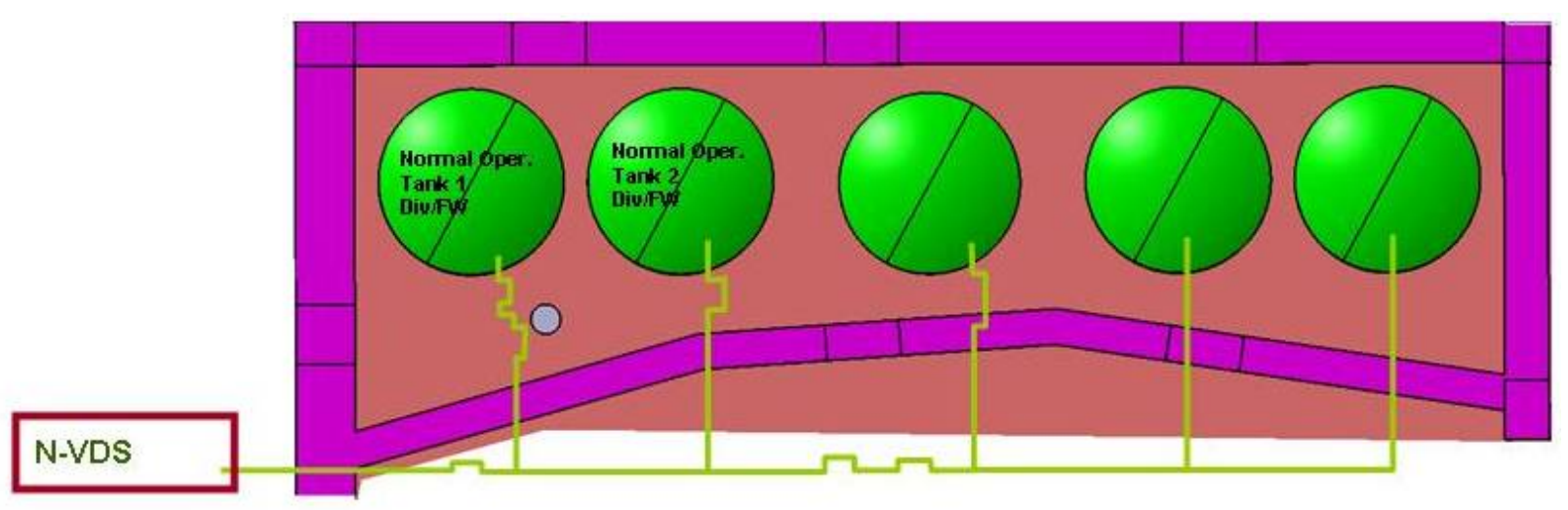

From: ITER TCWS Interface Document

Utility Needs, TIERSD/4NG/0004724/000/01

Ed. 030603

Fig. B.3. N-VDSS interfaces.

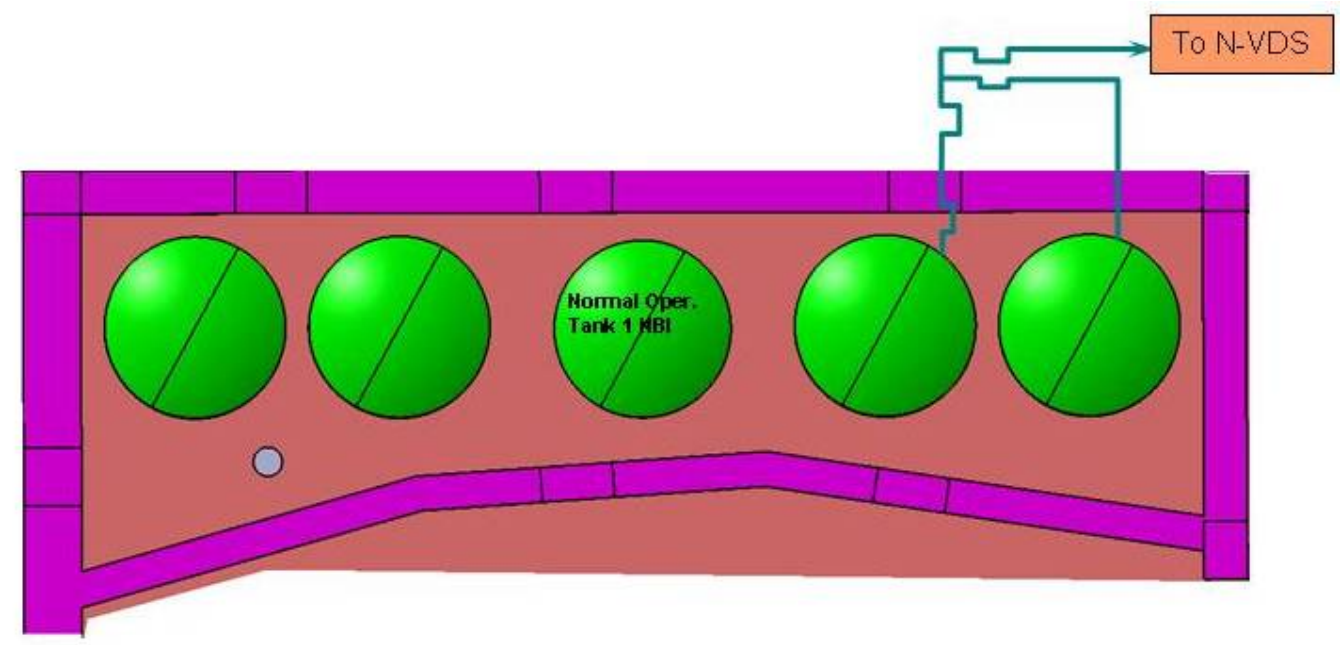

From: ITER TCWS Interface Document

Utility Needs, TIERSD/4NG/0004724/000/01

Ed. 030603

Fig. B.4. Vacuum interfaces. 


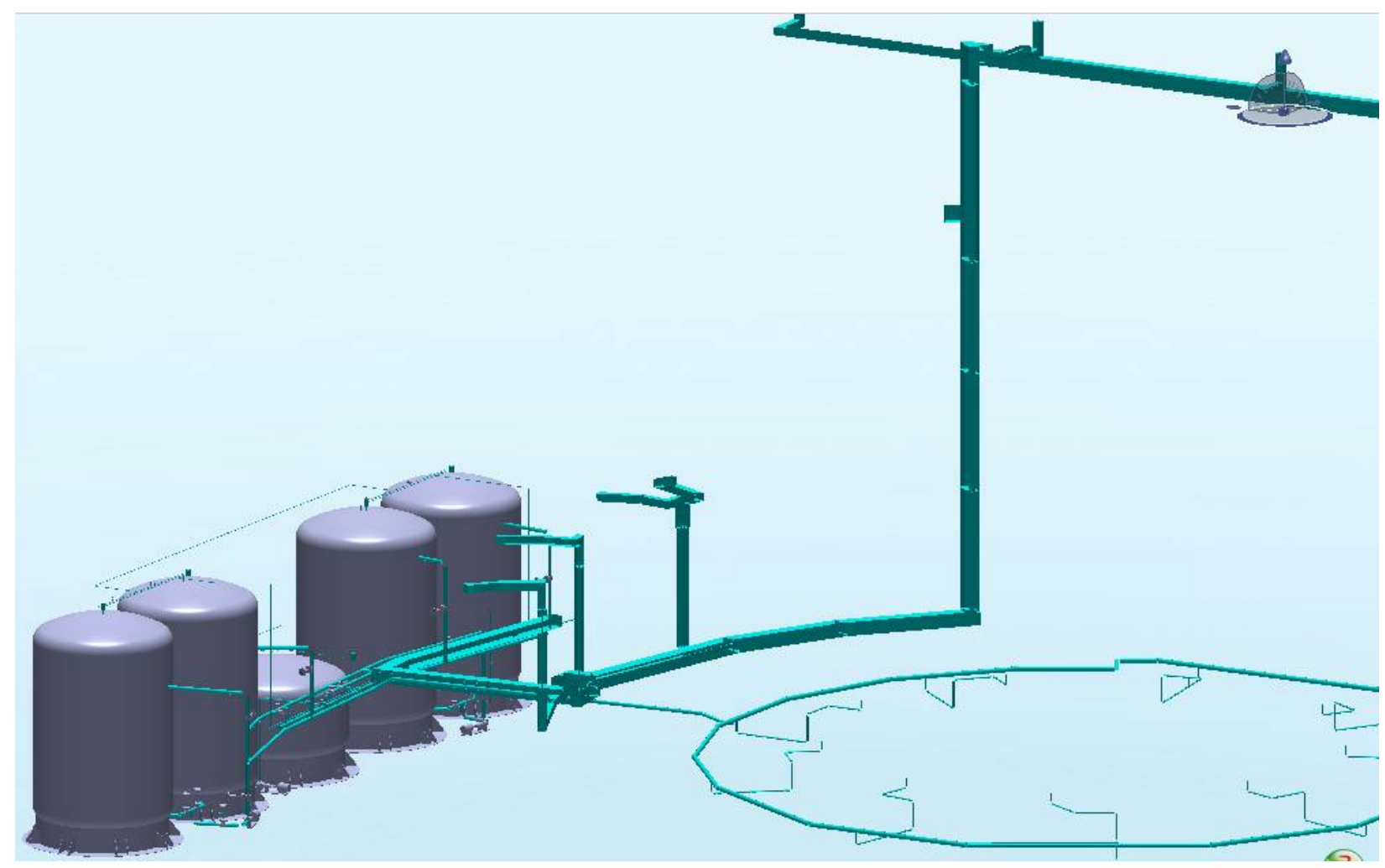

Fig. B.5. Computer-graphics-aided three-dimensional interactive application representation of the drain tanks and some of their interfaces. 




\section{APPENDIX C. \\ QUESTIONS ASKED BY AREVA ON INFORMATION FOR THE DESIGN BASIS OF THE DRAIN TANKS}





\section{APPENDIX C. QUESTIONS ASKED BY AREVA ON INFORMATION FOR THE DESIGN BASIS OF THE DRAIN TANKS}

\begin{tabular}{|c|c|c|c|c|}
\hline & Issue/Question & Reason & Comment & Response by US ITER \\
\hline 1 & $\begin{array}{l}3 \text { drain tanks vs. } \\
5\end{array}$ & $\begin{array}{l}\text { Design codes for both } \\
\text { safety and non-safety } \\
\text { are the same. } \\
\text { Redundancy may not } \\
\text { be required. }\end{array}$ & $\begin{array}{l}\text { US ITER will } \\
\text { discuss with } \\
\text { IO }\end{array}$ & $\begin{array}{l}\text { Redundancy is not the appropriate criteria to select the } \\
\text { number of tanks. The total net volume to be stored has } \\
\text { to be equivalent to the overall inventory of the water in } \\
\text { the concerned PHTS (plus small margin for } \\
\text { uncertainties). The volume of the safety tanks is } \\
\text { calculated as the volume to be drained after LOCA } \\
\text { event inside the VV (plus margin for uncertainties). The } \\
\text { number of both normal and emergency tanks is related } \\
\text { to the design criteria and available footprint and height } \\
\text { (volume) in the DT room. Based on this IO opinion we } \\
\text { should have } 5 \text { drain tanks. In addition, Areva needs to } \\
\text { consider the different functions of the safety \& normal } \\
\text { DTs. Having safety \& normal DTs is not because of } \\
\text { redundancy; but because of different chemistry of water } \\
\text { in the safety and normal DTs. We need to segregate } \\
\text { those two waters. The water in the safety DT will be } \\
\text { discharged to the Radwaste while the water in normal } \\
\text { DT will be reused to fill PHTSs. }\end{array}$ \\
\hline 2 & $\begin{array}{l}\text { Super heated } \\
\text { conditions into } \\
\text { drain tanks }\end{array}$ & $\begin{array}{l}\text { Based on design temp } \\
\text { and pressure, the } \\
\text { conditions are in super } \\
\text { heat conditions. May } \\
\text { involve two phase } \\
\text { flows. }\end{array}$ & $\begin{array}{l}\text { Volumes are } \\
\text { based on sub- } \\
\text { cooled liquid. } \\
\text { Actual liquid } \\
\text { volume } \\
\text { maybe higher. } \\
\text { Dynamic } \\
\text { loading } \\
\text { conditions. }\end{array}$ & $\begin{array}{l}\text { The water temperature for the drainage condition of the } \\
\text { safety drain tanks is the most stringent }(<100 \mathrm{C}) \text {. The } \\
\text { safety drain tanks are normally linked to the N-VDS } \\
\text { under vacuum pressure of about } 90 \mathrm{kPa} \text { absolute. } \\
\text { Therefore the pressure in the tanks needs to be } \\
\text { determined using transient analysis taking into account } \\
\text { both discharge and evaporation rate. US-ITER could } \\
\text { also use the same design condition for the normal drain } \\
\text { tanks. This means that the water could be discharge at a } \\
\text { max temperature of } 100 \mathrm{C} \text { during normal operation. } \\
\text { Different scenario of discharge needs to be justified by } \\
\text { US-ITER. Based on this IO opinion there is a need to } \\
\text { run a transient analysis to indeed analyze AREVA's } \\
\text { question. Topilski from IO already performed a } \\
\text { transient analysis and determined subcooled conditions } \\
\text { for the safety tanks. AREVA should check this matter } \\
\text { by performing a transient analysis if doubt persists. }\end{array}$ \\
\hline 3 & $\begin{array}{l}\text { Normalize use of } \\
\text { the words "drain } \\
\text { tanks" and } \\
\text { "safety drain } \\
\text { tanks" }\end{array}$ & & US ITER task & US ITER will do this in the report \\
\hline 4 & $\begin{array}{l}\text { "expected } \\
\text { volume" change } \\
\text { to "working } \\
\text { volume" }\end{array}$ & & US ITER task & US ITER will do this in the report \\
\hline
\end{tabular}




\begin{tabular}{|c|c|c|c|c|}
\hline & Issue/Question & Reason & Comment & Response by US ITER \\
\hline 5 & $\begin{array}{l}\text { Can sump tank } \\
\text { for DIV be used } \\
\text { for VV? }\end{array}$ & $\begin{array}{l}\text { Defer to later date } \\
\text { since it doesn't impact } \\
\text { the specs. }\end{array}$ & & $\begin{array}{l}\text { IO would like to consider only one sump tank of } 4 \mathrm{~m}^{3} \\
\text { connected to the Drying system. During the gravity } \\
\text { drain of the VV there is the risk of not sufficient height } \\
\text { from the bottom of the Lower Pipe Chase to the level in } \\
\text { the DT to permit a full drainage. Therefore we could } \\
\text { link this drainage line to the same sump tank by using } \\
\text { an isolation valve. In conclusion, we will have one } \\
\text { sump tank that can be used for both DIV and VV } \\
\text { draining procedures. Certainly, after each procedure the } \\
\text { sump tank needs to be washed. }\end{array}$ \\
\hline 6 & $\begin{array}{l}\text { Forms for } \\
\text { concrete floor in } \\
\text { drain tank area }\end{array}$ & $\begin{array}{l}\text { Option one for tanks } \\
\text { to be installed before } \\
\text { the floor above may } \\
\text { not be feasible due to } \\
\text { forms required for } \\
\text { construction of } \\
\text { concrete floor above. }\end{array}$ & IO question & $\begin{array}{l}\text { TCWS IO's opinion is that to permit the pouring of the } \\
\text { floor above, temporary frames need to be used that will } \\
\text { interfere with the DTs. This means that this option will } \\
\text { be refused from the assembly group. This is one } \\
\text { question that we will ask from the construction people } \\
\text { by email and we will have a meeting with them when } \\
\text { we go to France in October. }\end{array}$ \\
\hline 7 & $\begin{array}{l}\text { Mezzamine } \\
\text { location changes } \\
\text { from center to } \\
\text { sides }\end{array}$ & & IO question & $\begin{array}{l}\text { The central location has been selected to minimize the } \\
\text { connection to the Lower Pipe Chase (this is important } \\
\text { for the proposed horizontal shaft to link the DT room to } \\
\text { the UPC at the ceiling of the B2 level). If the mezzanine } \\
\text { is on the one side of the DT room there is a higher } \\
\text { available surface but this not so important. This is IO's } \\
\text { opinion and we will perform the design with this in } \\
\text { mind. The mezzanine is considered at the center of the } \\
\text { space. }\end{array}$ \\
\hline 8 & $\begin{array}{l}\text { Imbeded bolts } \\
\text { for tanks } \\
\text { interference with } \\
\text { air pallets }\end{array}$ & & IO question & $\begin{array}{l}\text { We will discuss this issue with the IO construction and } \\
\text { assembly group. There has been a suggestion of using } \\
\text { screw anchor bolts that needs to be considered by the } \\
\text { construction and assembly group. US ITER will send } \\
\text { emails to the construction group. US ITER will add this } \\
\text { issue for discussion with the construction group when } \\
\text { we go France in October. }\end{array}$ \\
\hline 9 & $\begin{array}{l}\text { Seismic } \\
\text { requirement } \\
\text { inputs (check } \\
\text { with hedrick) }\end{array}$ & $\begin{array}{l}\text { Confirm with Hedrick } \\
\text { that the document is } \\
\text { most accurate and } \\
\text { updated. If not } \\
\text { available, inform Juan }\end{array}$ & & $\begin{array}{l}\text { US ITER will provide what we think is the most } \\
\text { appropriate and recent seismic analysis that involves } \\
\text { level B2. It will be posted in SharePoint as the same } \\
\text { time that AREVA receives this spreadsheet. }\end{array}$ \\
\hline
\end{tabular}




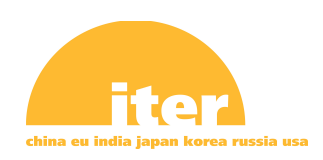

\begin{tabular}{|c|c|c|c|c|}
\hline & Issue/Question & Reason & Comment & Response by US ITER \\
\hline 10 & $\begin{array}{l}\text { Why does the } \\
\text { VVPSS drain to } \\
\text { drain tanks } \\
\text { instead of } \\
\text { radwaste? }\end{array}$ & $\begin{array}{l}\text { How does draining } \\
\text { from VVPSS work? }\end{array}$ & IO question & $\begin{array}{l}\text { ITER IO CWS has refused the storage of the VVPSS } \\
\text { drainage into the TCWS DTs. The drainage line from } \\
\text { the VVPSS could be merged with the TCWS drainage } \\
\text { line to have a unique connection to the Radwaste. In } \\
\text { conclusion, it is the opinion of the TCWS IO group that } \\
\text { we will not have an interface with the VVPSS. This } \\
\text { will be finally determined when the interface sheet is } \\
\text { finally approved. However, the SRD } 26 \text { (v } 2.1 \text { ), Section } \\
2.2 \text { will be modified to say: "Safety drain tanks shall } \\
\text { include features that will facilitate cleaning to allow the } \\
\text { restart of the plant within one year of such } \\
\text { occurrence." After the waste water has been processed, } \\
\text { the water collected in the VVPSS may be discharged to } \\
\text { the safety drain tanks following the in-vessel leak, } \\
\text { however, the piping connection between the VVPSS } \\
\text { and the TCWS safety drain tank shall be provided by } \\
\text { the VVPSS. This aspect is still in discussion. }\end{array}$ \\
\hline 11 & $\begin{array}{l}\text { Design pressure } \\
\text { scenario } \\
\text { discussions }\end{array}$ & $\begin{array}{l}\text { 1MPa design pressure } \\
\text { (from N2 supply } \\
\text { pressure) should not } \\
\text { be used as a design } \\
\text { basis. This issue } \\
\text { should be addressed } \\
\text { with the relief device } \\
\text { and not a basis for } \\
\text { design pressure for } \\
\text { tanks. AFS proposes } \\
\text { to use maxium static } \\
\text { head for design } \\
\text { pressure }\end{array}$ & & $\begin{array}{l}\text { In general ITER IO would agree, but we need to also } \\
\text { consider that these tanks could be also pressurized by } \\
\mathrm{N} 2 \text { to permit the pumping to the Radwaste. The max } \\
\text { pressurization of the } \mathrm{N} 2 \text { is } 0.8 \mathrm{MPa} \text {. Therefore, the } \\
\text { relief valve cannot be set below this limit. In addition } \\
\text { the pressure relief tank has been design for } 1 \mathrm{MP} \text { and } \\
\text { the operating pressure to } 0.5 \mathrm{MPa} \text {. From these } \\
\text { observations it would be appropriate to have } 1 \mathrm{MPa} \text { as } \\
\text { the design pressure for the tanks. }\end{array}$ \\
\hline 12 & $\begin{array}{l}\text { FMEA effect on } \\
\text { relief valves } \\
\text { (Tim Dodson) }\end{array}$ & $\begin{array}{l}\text { Informed Tim Dodson } \\
\text { and his team to start } \\
\text { work on FMEA for } \\
\text { drain tanks early }\end{array}$ & & $\begin{array}{l}\text { Informed Tim Dodson and his team to start work on } \\
\text { FMEA for drain tanks early }\end{array}$ \\
\hline 13 & $\begin{array}{l}\text { NBI connection } \\
\text { to drying system- } \\
\text { mistake on slide? }\end{array}$ & $\begin{array}{l}\text { US. ITER to review } \\
\text { figure } 11 \text { for services } \\
\text { to tanks }\end{array}$ & & This will be fixed in the document by US ITER \\
\hline 14 & $\begin{array}{l}\text { Minimum design } \\
\text { metal } \\
\text { temperature }\end{array}$ & $\begin{array}{l}\text { US ITER (Juan) to } \\
\text { provide }\end{array}$ & & $\begin{array}{l}\text { At B2 level ( }-11.6 \mathrm{~m} \text { below the ground level) the } \\
\text { minimum design temperature has been established at } 12 \\
\text { C. US ITER will provide a list of environmental } \\
\text { variables and their values at the same time this } \\
\text { spreadsheet is delivered. }\end{array}$ \\
\hline 15 & $\begin{array}{l}\text { Electrical } \\
\text { grounding for } \\
\text { drain tanks }\end{array}$ & $\begin{array}{l}\text { How many grounding } \\
\text { lugs will be required } \\
\text { for each tank }\end{array}$ & IO question & $\begin{array}{l}\text { It is not established yet. We need to uniform this } \\
\text { according to the indications from the electrical section. I } \\
\text { presume that could be at least two. However, there will } \\
\text { be a workshop on TCWS I\&C during October where } \\
\text { this question will be definitively answered. }\end{array}$ \\
\hline
\end{tabular}




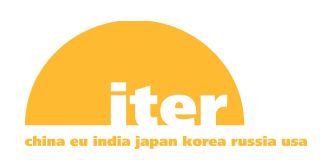

\begin{tabular}{|c|c|c|c|c|}
\hline & Issue/Question & Reason & Comment & Response by US ITER \\
\hline 16 & $\mathrm{I} \& \mathrm{C}$ & $\begin{array}{l}\text { Need to confirm } \\
\text { control safety and date } \\
\text { acquisition } \\
\text { redundancy }\end{array}$ & & $\begin{array}{l}\text { This is is a question that should be discussed during the } \\
\text { TCWS I\&C workshop in October. From our point of } \\
\text { view } 2 / 3 \text { logic for safety monitoring and } 1 / 2 \text { for nomal } \\
\text { gauging. So we have to determine what to be monitored. } \\
\text { Level gauge is safety according to RPrS. But P\&T } \\
\text { monitoring, we have not seen these requiremens } \\
\text { described anywhere. }\end{array}$ \\
\hline 17 & $\begin{array}{l}\text { Tank } \\
\text { containmination } \\
\text { levels for } \\
\text { washdown for all } \\
\text { tanks }\end{array}$ & $\begin{array}{l}\text { Required to know for } \\
\text { radiological and } \\
\text { cleanliness associated } \\
\text { with drain tanks for } \\
\text { tank design }\end{array}$ & IO question & $\begin{array}{l}\text { This issue needs to be discussed with IO Safety Section } \\
\text { to asses the ORE during maintenance due to the residual } \\
\text { radionuclides in the DTs. US ITER's opinion is that the } \\
\text { basis for this range of concentrations should come from } \\
\text { contaminated tank from solutions with concentrations } \\
\text { from Table } 6 \text { on the report on "Drain Tank Information } \\
\text { for Developig Design Basis of the Preliminary Design." } \\
\text { Once the liquid with this concentration abandons the } \\
\text { tank and the tank is washed then the residuals constitute } \\
\text { the lower range of contamination. However, IO TCWS } \\
\text { opinion is that we need to talk to Safety. We will do } \\
\text { that. }\end{array}$ \\
\hline 18 & $\begin{array}{l}\text { Surface finish of } \\
\text { tank ID vs. } \\
\text { required decon }\end{array}$ & Same as item 17 & & $\begin{array}{l}\text { We suggest using the best industrial practices. AREVA } \\
\text { should suggest methodologies. US ITER should } \\
\text { participate in the evaluation. }\end{array}$ \\
\hline 19 & $\begin{array}{l}\text { Update "drain } \\
\text { tank } \\
\text { classification } \\
\text { table" }\end{array}$ & $\begin{array}{l}\text { Need to reconcile } \\
\text { table } 5 \text { with Fan Li's } \\
\text { table }\end{array}$ & IO question & $\begin{array}{l}\text { Drain tank classification table is being sent to ITER IO } \\
\text { for their approval. We hope to update this information } \\
\text { in report "Drain Tank Information for Developing } \\
\text { Design Basis of the Preliminary Design" as soon as we } \\
\text { get the approval from IO. }\end{array}$ \\
\hline 20 & $\begin{array}{l}\text { Personnel } \\
\text { protection } \\
\text { requirement near } \\
\text { tanks-shielding, } \\
\text { insulation? }\end{array}$ & $\begin{array}{l}\text { Coordinate with HFE } \\
\text { engineer. Operational } \\
\text { issues and French } \\
\text { safety standards }\end{array}$ & IO question & $\begin{array}{l}\text { This issue needs to be discussed with IO Safety Section } \\
\text { to assess the ORE during maintenance due to the } \\
\text { residual radionuclides in the DTs. We also need to have } \\
\text { access to RPrS. We are planning to discuss this issue } \\
\text { with the Safety people in our visit to Cadarache in } \\
\text { October. }\end{array}$ \\
\hline 21 & $\begin{array}{l}20 \text { years or } 30 \\
\text { years for } \\
\text { corosion } \\
\text { allowance }\end{array}$ & $\begin{array}{l}\text { Operational conditions } \\
\text { after decomission } \\
\text { associated with } \\
\text { corrosion allowance } \\
\text { built-in the tank } \\
\text { design }\end{array}$ & IO question & $\begin{array}{l}\text { The drain tanks will have to be designed for } 40 \text { years. } \\
\text { After } 20 \text { years of operation, liquids will be stored in } \\
\text { drain tanks for decommissioning the plant. This number } \\
\text { is being given by IO and reflects these thoughts. }\end{array}$ \\
\hline 22 & $\begin{array}{l}\text { Passivation } \\
\text { treatment on SS } \\
\text { surface }\end{array}$ & $\begin{array}{l}\text { Do we need } \\
\text { passivation treatment }\end{array}$ & $\begin{array}{l}\text { Andrei's } \\
\text { question }\end{array}$ & $\begin{array}{l}\text { AREVA should make recommendations and US ITER } \\
\text { should make decisions based on value engineering } \\
\text { principles. }\end{array}$ \\
\hline 24 & $\begin{array}{l}\text { Allow the use of } \\
\text { 304L and } 316 \mathrm{~L}\end{array}$ & $\begin{array}{l}\text { This will give vendors } \\
\text { flexibility associated } \\
\text { with material costs }\end{array}$ & $\begin{array}{l}\text { US ITER SS } \\
\text { experts }\end{array}$ & US ITER agrees with this principle. \\
\hline 25 & $\begin{array}{l}\text { What is the } \\
\text { cleaning medium } \\
\text { for compatibility } \\
\text { with the metal? }\end{array}$ & $\begin{array}{l}\text { Operation pressure for } \\
\text { demin system (relate } \\
\text { to item } 17 \text { ) }\end{array}$ & & $\begin{array}{l}\text { We are getting this information from IO. It is } \\
\text { demineralized water }\end{array}$ \\
\hline
\end{tabular}




\begin{tabular}{|l|l|l|l|l|}
\hline & Issue/Question & Reason & Comment & \multicolumn{1}{c|}{ Response by US ITER } \\
\hline 26 & $\begin{array}{l}\text { Name plate } \\
\text { standards size } \\
\text { location? }\end{array}$ & IO question & $\begin{array}{l}\text { This information in not yet available. IO TCWS } \\
\text { suggests that the best option could be in the cylindrical } \\
\text { shell at } 1.8 \mathrm{~m} \text { from the floor level to be better readable. } \\
\text { However, AREVA should supply best practice for this } \\
\text { kind of tanks. }\end{array}$ \\
\hline 27 & $\begin{array}{l}\text { Transmitters 2 } \\
\text { out of 3 } \\
\text { requirements for } \\
\text { safety related } \\
\text { tanks? }\end{array}$ & $\begin{array}{l}\text { Kofi's } \\
\text { question }\end{array}$ & $\begin{array}{l}\text { This is a question that should be discussed during the } \\
\text { TCWS I\&C workshop in October. DDD specifies } 2 / 3 \\
\text { logic for safety monitoring and } 1 / 2 \text { for normal gauging. }\end{array}$ \\
\hline
\end{tabular}

